\title{
CONFIGURAÇÃO DO SISTEMA RADICULAR DAS ÁRVORES DE Eucalyptus grandis EM RESPOSTA À APLICAÇÃO DE DOSES CRESCENTES DE BIOSSÓLIDO
}

LUIZ FERNANDO DA SILVA MARTINS

Biólogo

Orientador: Prof. Dr. FÁBIO POGGIANI

Dissertação apresentada à Escola Superior de Agricultura "Luiz de Queiroz", Universidade de São Paulo, para obtenção do título de Mestre em Recursos Florestais, Área de Concentração: Recursos Florestais, com opção em Manejo de Florestas de Produção.

P I R A C I C A B A

Estado de São Paulo - Brasil

Fevereiro - 2002 


\section{ERRATA}

Luiz Fernando da Silva Martins

Configuração do sistema radicular das árvores de Eucalyptus grandis em resposta à aplicação de doses crescentes de biossólido

p.

item

Substituir o eixo $\mathrm{x}$ dos gráficos:

51

58

4.3

4.4

63

4.5 


\title{
Dados Internacionais de Catalogação na Publicação (CIP) DIVISĀO DE BIBLIOTECA E DOCUMENTAÇĀO - ESALQ/USP
}

\author{
Martins, Luiz Femando da Silva \\ Configuração do sistema radicular das ánores de Eucalyptus grandis em reposta à \\ aplicação de doses crescentes de biossólido / Luiz Femando da Silva Martins. - - \\ Piracicaba, 2002. \\ 73 p. : il. \\ Dissertação (mestrado) - - Escola Superior de Agricultura Luiz de Queiroz, 2002. \\ Bibliografia.
}

1 Adubo de lodo 2. Eucalipto 3. Sistema radicular I. Título

CDD 634.9734 
"O importante não é estar aqui ou ali, mas ser...

E ser é uma ciência delicada, feita de pequenas e grandes observações do cotidiano, dentro e fora da gente.

Se não ... executamos estas observações, não chegamos a ser, apenas estamos e Desaparecemos".

Carlos Drummond de Andrade 


\section{A Deus}

Pela certeza de ter-me acompanhado em todos os momentos, sem o qual nada disso seria possivel,

\section{OFEREÇO}

\section{Aos meus pais}

Roberto e Zélia, pelo amor, incentivo e dedicação em todos os momentos da minha vida...

\section{Aos meus irmãos}

Pela demonstração de carinho e presença sempre constante; e pequenos sobrinhos, geração de um novo mundo

Com muito amor e gratidão, DEDICO 


\section{AGRADECIMENTOS}

A todos os professores do Departamento de Ciências Florestais da Escola Superior de Agricultura "Luiz de Queiroz", pelos preciosos ensinamentos e pela colaboração na condução deste trabalho;

Ao Prof. Dr. Fábio Poggiani, pela orientação precisa, compreensão, confiança e exemplo profissional;

Ao Centro de Apoio à Pesquisa do Estado de São Paulo (CAPES), pelo auxílio financeiro através da bolsa concedida;

Ao Horto Florestal de Itatinga, que possibilitou a realização deste trabalho, assim como ao Engenheiro Florestal Rildo Moreira e Moreira e a todos os funcionários;

À amiga Camila Preza Yazbek, pela valiosa ajuda nas atividades de campo com a única recompensa de aprender algo mais;

Ao amigo Marcelino Carneiro Guedes, pela ajuda nas análises estatísticas e pelas valiosas sugestões;

Ao Laboratório de Ecologia Aplicada na pessoa da Química Alba Valéria Mosetto e técnicas Juliana, Fernanda e Ana Paula, pela paciente orientação e execução das análises laboratoriais;

Ao Prof. Dr. Ricardo Ferraz de Oliveira do Laboratório de plantas cultivadas sob condições de estresse do Departamento de Botânica da ESALQ, pelas sugestões dadas ao trabalho e principalmente no empréstimo de equipamentos e infra-estrutura.

À Engenheira Agrônoma Miriam Ferraz Moreira, pela ajuda no Summary e pelas outras tantas ajudas... 
Às amigas Márcia Toffani e Elizabeth Menezes Lopes, pela constante presença, força e pelos papos sobre "o nada";

Aos amigos do Raja Yoga, sempre dando força nos momentos mais difíceis, amizade, compreensão e companheirismo no caminho do auto conhecimento;

Aos colegas do Curso de Pós-graduação e demais funcionários do Departamento de Ciências Florestais da Escola Superior de Agricultura "Luiz de Queiroz", pelo convívio e amizade;

Aos meus pais, pelo amor e pelo socorro financeiro nas horas de aperto e por sempre terem me apoiado em minhas decisões e indecisões;

Aos meus irmãos, cunhadas e sobrinhos, que entenderam minha ausência e tanta dedicação a este trabalho, torcendo por mim todo o tempo;

A todos que direta ou indiretamente me ajudaram a vencer mais essa etapa da minha vida... 


\section{SUMÁRIO}

Página

LISTA DE FIGURAS........................................................................................... ix

LISTA DE TABELAS................................................................................. xiii

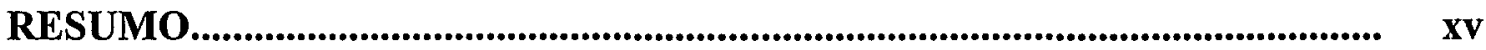

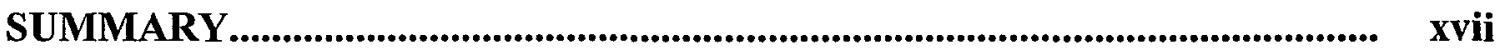

1 INTRODUÇÃ

2 REVISÃO DE LITERATURA.................................................................. 03

$2.1 \mathrm{O}$ uso do lodo de esgoto (Biossólido) em sistemas agroflorestais....................... 03

2.1.1 Produção do lodo de esgoto................................................................................. 03

2.1.2 Legislação Ambiental................................................................................. 05

2.1.3 Efeito do lodo de esgoto (biossólido) sobre a produtividade florestal............. 08

2.1.4 Caracterização de biossólidos......................................................................... 11

2.2 O ESTUDO DE RAÍZES FINAS DAS ÁRVORES....................................... 14

2.2.1 Classificação de raízes finas.......................................................................... 14

2.2.2 Distribuição de raízes finas......................................................................... 15

2.2.3 Produção e renovação de raízes finas.................................................................. 16

2.2.4 Método de estudo do sistema radicular............................................................ 19

2.3 AVALIAÇÃO DE PARÂMETROS RADICULARES................................ 20

2.3.1 Comprimento de raízes finas (Densidade)........................................................ 20

2.3.2 Diâmetro de raízes finas............................................................................... 21

2.3.3 Superfície de raízes finas ou rizoplano........................................................ 21

2.4 A LUZ EM FLORESTAS E SEUS EFEITOS SOBRE O CRESCIMENTO

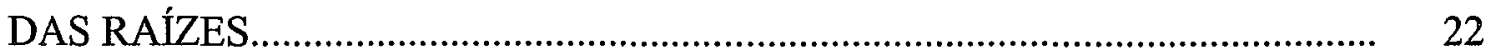


3 MATERIAL E MÉTODOS........................................................................... 24

3.1 DESCRIÇÃO DA ÁREA EXPERIMENTAL ............................................... 24

3.1.1 Localização geográfica.............................................................................. 24

3.1.2 Histórico e vegetação................................................................................... 25

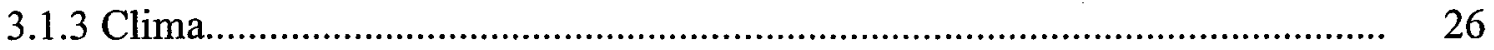

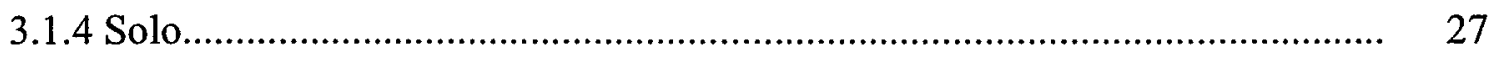

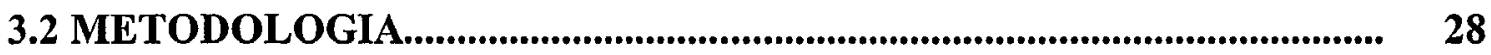

3.2.1 Delineamento experimental e tratamentos....................................................... 28

3.2.2 Caracterização e aplicação do biossólido utilizado......................................... 29

3.2.3 Determinação da área basal....................................................................... 30

3.2.4 Estudo do microclima................................................................................... 31

3.2.4.1 Luz incidente no sub-bosque.............................................................. 32

3.2.4.2 Temperatura do solo nos diferentes tratamentos.......................................... 32

3.2.5 Coleta de raízes finas..................................................................................... 32

3.2.6 Lavagem e separação de raízes finas............................................................. 34

3.2.7 Comprimento e diâmetro de raízes finas........................................................... 35

4 RESULTADOS E DISCUSSÃO............................................................................ 37

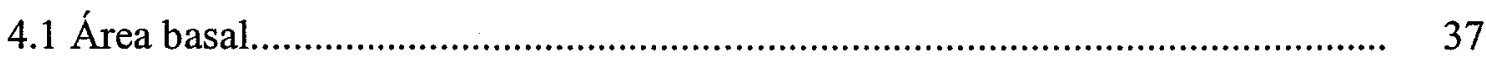

4.2 Estudo do microclima..................................................................................... 40

4.2.1 Luz incidente no sub-bosque.................................................................... 40

4.2.2 Temperatura do solo nos diferentes tratamentos............................................ 42

4.3 Densidade de raízes finas............................................................................... 44

4.4 Diâmetro de raízes finas................................................................................ 52

4.5 Superfície específica de raízes finas............................................................... 59

5 CONCLUSÕES.................................................................................................... 64

REFERÊNCIAS BIBLIOGRÁFICAS............................................................... 65 


\section{LISTA DE FIGURAS}

Página

1 Localização do município de Itatinga, Estado de São Paulo.

2 Localização das áreas experimentais e de produção na Estação Experimental de Itatinga, Estado de São Paulo.

3 Médias mensais das temperaturas máximas ( $\mathrm{T}$ max.) e temperaturas mínimas ( $\mathrm{T}$ min.) e valores de precipitação pluviométrica $(\mathrm{P})$, no período de julho de 1998 a fevereiro de 2001

4 Sonda de $4 \mathrm{~cm}$ de diâmetro com $80 \mathrm{~cm}$ de comprimento usada para amostragem de raízes finas.

5 Lavador e separador de raízes Delta T Root Washer

6 Imagem digitalizada de uma amostra de raízes finas retirada na profundidade entre 10 e $30 \mathrm{~cm}$ na linha de plantio, obtida pela varredura de um "scanner" de mesa com resolução de 400 dpi...............

7 Valores médios $(\mathrm{N}=36)$ da área basal das árvores de eucalipto, medidas em janeiro de 2001, aos 35 meses após o plantio. 
8 Valores médios $(M)$ e \pm erro padrão (EP) da radiação fotossinteticamente ativa no sub-bosque do talhão experimental, em fevereiro de 2001, 36 meses após o plantio $(\mathrm{N}=20)$. Médias seguidas da mesma letra não diferem estatisticamente pelo teste Tukey a $5 \%$ de probabilidade...

9 Temperatura do solo (média \pm erro padrão) registrada na superfície do solo e a $10 \mathrm{~cm}$ de profundidade, em fevereiro de 2001. Médias seguidas da mesma letra não diferem estatisticamente pelo teste Tukey a $5 \%$ de probabilidade

10 Densidade de raízes finas (média \pm erro padrão), na camada entre 0 e $10 \mathrm{~cm}$ e 10 e $30 \mathrm{~cm}$ de profundidade nas parcelas experimentais de Eucalyptus grandis aos 3 anos de idade. Médias seguidas da mesma letra não diferem estatisticamente pelo teste Tukey a $5 \%$ de probabilidade.

11 Densidade de raízes finas (média \pm erro padrão) na camada entre 0 e $10 \mathrm{~cm}$ de profundidade, nas linhas de plantio. Médias seguidas da mesma letra não diferem estatisticamente pelo teste Tukey a $5 \%$ de probabilidade.

12 Densidade de raízes finas (média \pm erro padrão) na camada entre $0 \mathrm{e}$ $10 \mathrm{~cm}$ de profundidade, nas entrelinhas de plantio. Médias seguidas da mesma letra não diferem estatisticamente pelo teste Tukey a $5 \%$ de probabilidade 
13 Densidade de raízes finas coletadas nas linhas de plantio na camada entre 0 e $10 \mathrm{~cm}$ de profundidade, em função das doses crescentes de

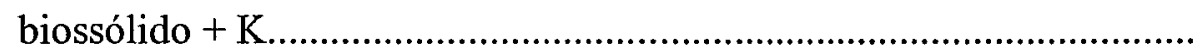

14 Diâmetro de raízes finas (média \pm erro padrão), na camada entre 0 e $10 \mathrm{~cm}$ e 10 e $30 \mathrm{~cm}$ de profundidade nas parcelas experimentais de Eucalyptus grandis aos 3 anos de idade. Médias seguidas da mesma letra não diferem estatisticamente pelo teste Tukey a $5 \%$ de probabilidade.

15 Diâmetro de raízes finas (média \pm erro padrão), na camada entre $0 \mathrm{e}$ $10 \mathrm{~cm}$, nas linhas de plantio. Médias seguidas da mesma letra não diferem estatisticamente pelo teste Tukey a $5 \%$ de probabilidade...........

16 Diâmetro de raízes finas (média \pm erro padrão) na camada entre 0 e 10 $\mathrm{cm}$, nas entrelinhas de plantio. Médias seguidas da mesma letra não diferem estatisticamente pelo teste Tukey a 5\% de probabilidade.

17 Diâmetro médio de raízes finas coletadas nas linhas (A) e nas entrelinhas (B) de plantio na camada entre 0 e $10 \mathrm{~cm}$, em função das doses crescentes de biossólido + K.......................................................

18 Superfície específica de raízes finas (média \pm erro padrão) na camada entre 0 e 10 e 10 e $30 \mathrm{~cm}$ nas parcelas experimentais. Médias seguidas da mesma letra não diferem estatisticamente pelo teste Tukey a $5 \%$ de probabilidade 
19 Superfície específica de raízes finas (média \pm erro padrão), na camada entre 0 e $10 \mathrm{~cm}$, nas linhas de plantio. Médias seguidas da mesma letra não diferem estatisticamente pelo teste Tukey a $5 \%$ de

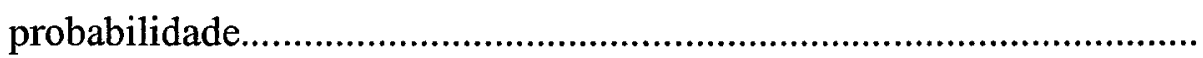

20 Superfície específica de raízes finas (média \pm erro padrão), na camada entre 0 e $10 \mathrm{~cm}$ nas entrelinhas de plantio. Médias seguidas da mesma letra não diferem estatisticamente pelo teste Tukey a $5 \%$ de

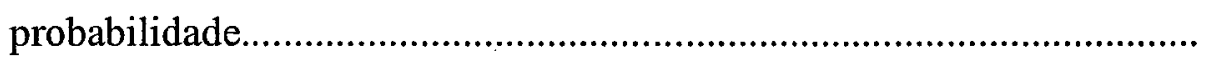

21 Superfície específica de raízes finas coletadas nas linhas (A) e nas entrelinhas (B) de plantio na camada entre 0 e $10 \mathrm{~cm}$, em função das

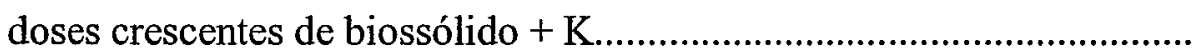




\section{LISTA DE TABELAS}

Página

1 Principais parâmetros de valor agronômico produzidos em diversas ETEs do Brasil (Tsutya, 2001)

2 Principais características química e física do Latossolo VermelhoAmarelo da área experimental segundo Vaz (2000)..................................

3 Característica do biossólido utilizado: elementos totais, base seca a $65^{\circ} \mathrm{C}$ produzido pela ETE Barueri, Guedes (2000)

4 Resumo da ANOVA realizada para a densidade de raízes finas $(\mathrm{cm}$ $\mathrm{cm}^{-3}$ ) de eucalipto, em função de doses crescentes de biossólido e adubação mineral, na camada entre $0 \quad$ e $10 \quad \mathrm{~cm}$ de profundidade.

5 Resumo da ANOVA realizada para a densidade de raízes finas (cm $\mathrm{cm}^{-3}$ ) de eucalipto, em função de doses crescentes de biossólido e adubação mineral, na camada entre 10 e $30 \mathrm{~cm}$ de profundidade

6 Resumo da ANOVA realizada para o diâmetro médio de raízes finas (mm) de eucalipto, em função de doses crescentes de biossólido e adubação mineral na camada entre 0 e $10 \mathrm{~cm}$ de profundidade. 
7 Resumo da ANOVA realizada para o diâmetro médio de raízes finas (mm) de eucalipto, em função de doses crescentes de biossólido e adubação mineral na camada entre 10 e $30 \mathrm{~cm}$ de profundidade............... 


\title{
CONFIGURAÇÃO DO SISTEMA RADICULAR
}

\section{DAS ÁRVORES DE Eucalyptus grandis EM RESPOSTA À APLICAÇÃO DE DOSES CRESCENTES DE BIOSSÓLIDO}

\author{
Autor: LUIZ FERNANDO DA SILVA MARTINS \\ Orientador: Prof. Dr. FÁBIO POGGIANI
}

\section{RESUMO}

O crescimento das demandas da sociedade por melhores condições do ambiente, tem exigido das empresas públicas e privadas definição de políticas ambientais mais avançadas entre as quais se destacam o tratamento dos efluentes. Este tratamento gera um resíduo sólido denominado de biossólido (lodo de esgoto tratado e higienizado), cuja aplicação em florestas plantadas vem sendo enfocada como a melhor alternativa. Este estudo teve como objetivo avaliar o efeito da aplicação de doses crescentes de biossólido sobre o sistema radicular de absorção de uma plantação de eucaliptos. A pesquisa foi conduzida em uma área de plantio de Eucalyptus grandis Hill ex Maiden, com 3 anos de idade, localizada na Estação Experimental de Itatinga da Escola Superior de Agricultura "Luiz de Queiroz"/USP em Itatinga, Estado de São Paulo. O delineamento experimental foi o de parcelas de $600 \mathrm{~m}^{2}$, com 6 tratamentos e 4 blocos. Cada parcela foi constituída por 100 plantas, ou seja, 10 linhas com 10 plantas cada. O biossólido foi aplicado apenas em faixas de 2 metros de largura nas entrelinhas de plantio. Os tratamentos foram constituídos por: 1) Testemunha "Tt"; 2) Adubação mineral "Ad"; 3) 10t ha" de 
biossólido com potássio "10t+K"; 4) $10 \mathrm{t} \mathrm{ha}^{-1}$ de biossólido com potássio e fósforo “10t+KP"; 5) 20t ha ${ }^{-1}$ de biossólido com potássio "20t+K"; e 6) 40t ha ${ }^{-1}$ de biossólido com potássio "40t+K". Para a amostragem das raízes finas, foi utilizada uma sonda cilíndrica de aço inoxidável com $4 \mathrm{~cm}$ de diâmetro. A distribuição de raízes finas no perfil do solo foi determinada nas camadas entre 0-10 e 10-30 cm de profundidade nas linhas e nas entrelinhas de plantio. As raízes finas contidas nas amostras de solo foram lavadas e tiveram seu comprimento e diâmetro médio determinado pelo sistema Delta $\mathrm{T}$ SCAN. Durante o período de coleta foi monitorado o microclima do sub-bosque (temperatura do solo e luminosidade). Os tratamentos " $10 \mathrm{t}+\mathrm{KP}$ " $\mathrm{e}$ " $40 \mathrm{t}+\mathrm{K}$ " foram os que apresentaram maior área basal. Nas parcelas amostradas o "Tt" apresentou área basal $38 \%$ inferior à área basal das árvores do " $10 \mathrm{t}+\mathrm{KP}$ ”. No tratamento " $40 \mathrm{t}+\mathrm{K}$ " foi registrado o menor valor de radiação fotossintéticamente ativa no sub-bosque $(64,1$ $\mu \mathrm{mol} \mathrm{cm} \mathrm{cm}^{-2}$ ) e no tratamento "Tt" o maior valor $\left(104,4 \mu \mathrm{mol} \mathrm{cm} \mathrm{cm}^{-2} \mathrm{~s}^{-1}\right)$. O valor médio da temperatura do solo na superfície nos tratamentos foi de $27,9^{\circ} \mathrm{C}$ e a $10 \mathrm{~cm}$ de profundidade foi de $26,1^{\circ} \mathrm{C}$. O valor da temperatura mais elevada foi observado no tratamento "Tt" devido à maior incidência de energia solar no sub-bosque. Quanto à densidade de raízes finas ( $\leq 3 \mathrm{~mm}$ de espessura), a maior concentração foi na camada superficial do solo $(0-10 \mathrm{~cm})$ com densidade média de $6,58 \mathrm{~cm} \mathrm{~cm}^{-3}$, com queda para $1,83 \mathrm{~cm} \mathrm{~cm}^{-3}$ na camada inferior do solo $(10-30 \mathrm{~cm})$, considerando as amostras coletadas nas linhas e entrelinhas. Os tratamentos que apresentaram maiores valores de densidade de raízes finas na camada superficial, foram o " $\mathrm{Tt}$ " $\left(8,20 \mathrm{~cm} \mathrm{~cm}^{-3}\right)$ e o "Ad" $(7,77 \mathrm{~cm}$ $\mathrm{cm}^{-3}$ ) e os menores valores foram observados nos tratamentos com biossólido, com média de $5,87 \mathrm{~cm} \mathrm{~cm}^{-3}$. Quanto ao diâmetro, em média, os maiores valores foram encontrados nas linhas de plantio $(0,47 \mathrm{~mm})$ e os menores valores $(0,38 \mathrm{~mm})$ nas entrelinhas. Na camada superficial, nas linhas de plantio, os tratamentos "Tt" e "Ad" foram os que apresentaram a maior superfície específica de raízes finas, com $1,36 \mathrm{~cm}^{2}$ $\mathrm{cm}^{-3}$ e $1,23 \mathrm{~cm}^{2} \mathrm{~cm}^{-3}$ respectivamente, ao passo que a menor superfície específica foi observada nos tratamentos com adição de biossólido com média de $0,76 \mathrm{~cm}^{2} \mathrm{~cm}^{-3}$. 


\title{
ROOT SYSTEMS PATTERN OF Eucalyptus grandis TREES RESPONSE TO INCREASING DOSES OF BIOSOLIDS
}

\author{
Author: LUIZ FERNANDO DA SILVA MARTINS \\ Adviser: Prof. Dr. FÁBIO POGGIANI
}

\section{SUMMARY}

The society demand for better environment conditions has required from the private and also not private companies a defined and more advanced politics for the sewer treatment. This treatment results in solid residues denominated biosolids (treated and hygienic sewage sludge) which was spread on planted forest seems to be the better solution. The aim of this study was to evaluate the use of increasing doses of biosolids over root systems of planted Eucalypt. The research was conducted with three years old planted Eucalyptus grandis Hill ex Maiden area, placed in the Experimental Station of Itatinga (ESALQ/USP), in Itatinga, São Paulo State. The experimental design was based in plots of $600 \mathrm{~m}^{2}$, with 6 treatments and 4 blocks. Each block had 100 plants (10 rows with 10 plants). The biosolids was applied only between the rows of planting. The treatments were: 1) control "Tt"; 2) inorganic fertilizes "Ad"; 3) 10t ha $\mathrm{af}^{-1}$ of biosolids with potassium "10t+K"; 4) $10 \mathrm{t} \mathrm{ha}^{-1}$ of biosolids with potassium and phosphorus 
"10t+KP"; 5) $20 \mathrm{t} \mathrm{ha} \mathrm{h}^{-1}$ of biosolids with potassium "20t+K"; 6) 40t ha $\mathrm{h}^{-1}$ of biosolids with potassium "40t+K". To sample the fine roots, it was used a stainless steel cylindrical probe with the diameter of $4 \mathrm{~cm}$. Fine roots distribution in the soil profile was established in the layers from $0-10$ and $10-30 \mathrm{~cm}$ in the row and in the area between the rows. The fine roots were washed and had the average length and thickness settled by Delta T Scan System. During the sample period the soil temperature and lightness of the understory were monitored. The "10+KP" and "40+K" showed bigger basal area of eucalypt treatments. The "Tt" presented basal area 38\% lower to the "10+KP" trees basal area. The " $40+\mathrm{K}$ " treatments presented the smaller value of photosynthetic radiation rate in the understory $\left(64,1 \mu \mathrm{mol} \mathrm{cm} \mathrm{cm}^{-2}\right)$ and the "Tt" treatment the highest value $(104,4$ $\mu \mathrm{mol} \mathrm{cm} \mathrm{cm}^{-2}$ ). The soil temperature in the treatments were, in average, $27,9^{\circ} \mathrm{C}$ on the soil surface and $26,1^{\circ} \mathrm{C}$ at $10 \mathrm{~cm}$ depth. The highest temperature value was in "Tt" treatment due to the bigger solar radiation in understory. The density average of eucalypt fine roots $\left(\leq 3 \mathrm{~mm}\right.$ thick), in the soil surface layer $(0-10 \mathrm{~cm})$ was $6,58 \mathrm{~cm} \mathrm{~cm}^{-3}$, and decreased to $1,88 \mathrm{~cm} \mathrm{~cm}^{-3}$ in the lower soil layer $(10-30 \mathrm{~cm})$. The treatments that presented higher fine roots density in the soil surface layer, were "Tt" $\left(8,20 \mathrm{~cm} \mathrm{~cm}^{-3}\right)$ and the "Ad" $\left(7,77 \mathrm{~cm} \mathrm{~cm}^{-3}\right)$. The smallest value $\left(5,87 \mathrm{~cm} \mathrm{~cm}^{-3}\right)$ was found in the treatments with biosolids. The highest diameter value $(0,47 \mathrm{~mm})$ was found in the planting rows, while the smallest value $(0,38 \mathrm{~mm})$ were found in the area between the rows. The treatments that presented fine roots with highest specific surface area were "Tt" $\left(1,36 \mathrm{~cm}^{2} \mathrm{~cm}^{-3}\right)$ and "Ad" $\left(1,23 \mathrm{~cm}^{2} \mathrm{~cm}^{-3}\right)$. The smallest root specific surface area was observed in treatments with biosolids with average $0,76 \mathrm{~cm}^{2} \mathrm{~cm}^{-3}$. 


\section{INTRODUÇÃO}

A crescente demanda por produtos florestais, em nível nacional e mundial, registrada nos últimos 50 anos, bem como, a intensa pressão exploratória sobre as matas nativas brasileiras têm estimulado a iniciativa pública e privada a implantar extensas áreas florestais com espécies de rápido crescimento.

Atualmente, o Brasil possui mais de 5 milhões de hectares com plantações homogêneas, predominando as espécies de Eucalyptus (65\%) e de Pinus (35\%) (Gonçalves et al., 2000), sendo portanto, o país que tem a maior área florestada do mundo, que atende basicamente a produção de papel, compensados, resina, etc.

As plantações florestais, geralmente, são implantadas em solos de baixa fertilidade, não mais utilizados pela agricultura e pecuária. Esses solos trazem consigo toda uma história de modificações em suas propriedades físico-químicas, como esgotamento nutricional e desestabilidade de agregados que podem levar a um reflexo negativo na produtividade do povoamento florestal.

A aplicação do biossólido (lodo de esgoto urbano tratado e higienizado), no solo de florestas plantadas e em áreas agrícolas, vem-se credenciando como a melhor alternativa para a disposição final desse resíduo (Raij, 1998).

Nos Estados Unidos, desde a década de 70 e mais recentemente na Austrália, diversas pesquisas vêm sendo desenvolvidas, destacando-se as alterações benéficas promovidas no solo pela aplicação do biossólido, proporcionados principalmente pela matéria orgânica e nutrientes presentes em sua composição, sendo estes os principais fatores que melhoram as características químicas e físicas do solo e elevam a 
produtividade das plantações florestais (Henry et al., 1994; Harrison et al., 1994; Polglase \& Myers, 1995).

O conteúdo de material orgânico presente na composição do biossólido promove no ambiente radicular alterações desejáveis, como aumento da capacidade de retenção de umidade, diminuição da resistência física à penetração de raízes, melhoria das condições de movimentação de nutrientes no solo, etc., e essas alterações são dificeis de serem quantificadas (Martins et al., 1997; Fisher \& Binkey, 2000).

Quantificar e conhecer a distribuição do sistema radicular no perfil do solo é de fundamental importância como fonte de subsídios para explicar processos ecofisiológicos básicos como a nutrição mineral e balanço hídrico de uma árvore.

Observando os estudos referentes à adição de biossólido em florestas plantadas, nota-se que há um aumento na produtividade florestal e melhorias nas características físicas, químicas e biológicas do solo. Será que esse aumento também ocorre no sistema radicular de absorção das árvores ?

Diante do exposto, este trabalho teve como objetivo avaliar o efeito de doses crescentes de biossólido, resultante do tratamento do lodo de esgoto da região metropolitana de São Paulo (Estação de Tratamento de Esgoto de Barueri), sobre a configuração do sistema radicular de absorção do Eucalyptus grandis. Neste sentido, foi verificado o efeito dos tratamentos com biossólido sobre a área basal das parcelas experimentais, a incidência de luz fotossinteticamente ativa no sub-bosque, a temperatura do solo e o efeito de doses crescentes de biossólido sobre a densidade, diâmetro e superfície específica das raízes finas dos eucaliptos na camada entre 0 e 10 $\mathrm{cm}$ e 10 e $30 \mathrm{~cm}$ de profundidade do solo. 


\section{REVISÃO DE LITERATURA}

\subsection{O uso do lodo de esgoto (Biossólido) em sistemas agroflorestais}

\subsubsection{Produção do lodo de esgoto}

Os esgotos certamente se apresentam como um dos problemas ambientais a serem enfrentados pelo homem no século XXI. As quantidades geradas são assustadoras, o que vem acelerando o ritmo de degradação dos recursos naturais.

Dados da Secretaria de Planejamento do governo brasileiro, citados por Luduvice (1998), dão conta de que até o ano de 1996 apenas 30\% dos esgotos produzidos em cidades brasileiras eram coletados sendo que, deste total, cerca de $8 \%$ recebiam algum tipo de tratamento.

Rogalla (1998) enfatiza que o processamento e destino dos resíduos gerados nos tratamentos dos esgotos não receberam muita atenção nos últimos anos. Uma razão é que, com cidades cada vez maiores e com padrões de lançamento dos efluentes cada vez mais restritivos, a produção de esgoto em áreas urbanas está crescendo, sem ter disponível o seu destino final.

Andreoli \& Pegorini (1998a) reportaram que 10 milhões de $\mathrm{m}^{3}$ de esgotos são coletados e despejados diariamente nos cursos d'água sem nenhum tratamento, situação que deve ser agravada pela inclusão de mais 70 milhões de habitantes nas redes coletoras nos próximos 15 anos.

Esta situação faz do tratamento dos esgotos uma prática indispensável para a preservação dos recursos hídricos. No entanto, desse tratamento resulta o lodo de esgoto 
(L.E.), cuja disposição final é problemática e pode representar $60 \%$ dos custos de operação de um estação de tratamento (Centro Nacional de Referência e Gestão Ambiental Urbana, 2001). Embora atualmente uma fração muito pequena dos esgotos seja tratado, quantidades significativas e crescentes de L.E. vem sendo gerados. Apenas na região metropolitana de São Paulo, SP, com a capacidade de tratamento instalada e em operação, gera-se diariamente em torno de 100 toneladas de L.E. seco, com uma previsão para o ano de 2005 de 575 toneladas diárias (Santos \& Tsutiya, 1997). No Estado do Paraná a produção atual está em torno de 29 toneladas diárias de LE seco, destacando-se a cidade de Curitiba, PR, com 20 toneladas diárias (Andreoli \& Pegorini, 1998a)

Segundo Luduvice (1998) L.E. é uma denominação genérica dado ao resíduo gerado pelos sistemas de tratamento de águas residuárias. Trata-se de um material heterogêneo, cuja composição depende do tipo de tratamento empregado para purificar o esgoto e das características das fontes geradoras (população e indústrias).

De modo geral o L.E. tem tido grande interesse agrícola, pelo seu conteúdo em nutrientes minerais, principalmente nitrogênio e fósforo além de outros macronutrientes e micronutrientes, mas especialmente pelo seu teor de matéria orgânica, cujos efeitos no solo se fazem sentir a longo prazo, melhorando sua resistência à erosão e à seca, ativando a vida microbiológica do solo e possivelmente aumentando a resistência das plantas às pragas (SANEPAR, 1997; Raij, 1998; Andreoli \& Pegorini, 1998b).

Andreoli \& Pegorini (1998b) salientam que o uso agrícola do L.E. foi exaustivamente pesquisado no mundo todo. Mais de 50.000 artigos científicos sobre o assunto já foram publicados, e nenhum efeito adverso do uso controlado do insumo foi encontrado. As regulamentações internacionais têm assegurado a proteção à saúde humana e animal, a qualidade das colheitas, do solo e do meio ambiente em todo o mundo. 


\subsubsection{Legislação Ambiental}

A humanidade desenvolveu-se nos últimos anos em função de tecnologias e sistemas de produção baseados na utilização dos recursos naturais e no despejo dos resíduos não aproveitáveis no meio ambiente. Por vários anos, o homem não teve a preocupação em repor os recursos utilizados e em auxiliar o meio ambiente no processo de assimilação dos resíduos.

Họje, porém, o homem sabe que muitos recursos são classificados como não renováveis, e que o meio ambiente possui um limite de assimilação. Portanto, a proteção do meio ambiente é uma condição necessária para a continuação do desenvolvimento sócio-econômico. Por proteção ambiental entende-se uma série de medidas de caráter econômico, político e social, que visam o desenvolvimento sustentável da humanidade.

Quaisquer medidas que forem tomadas, é necessária a regulamentação, ou seja, a necessidade de impor normas e leis, a fim de que determinados padrões e diretrizes sejam seguidos. No caso específico da disposição final do L.E., diversos países elaboraram padrões e diretrizes para as diversas alternativas de disposição. Esses padrões e diretrizes foram elaborados de acordo com as características de cada país, e de acordo com as características físico-químicas do L.E. (Rocha, 1998).

LEGISLAÇÃO NORTE AMERICANA - O país que merece destaque tanto pelo rigor, como pela maneira que conduziu a elaboração das normas para a disposição final do L.E., são os EUA. Conhecida como "503", a legislação norte-americana, intitulada "Padrões para o uso e disposição do lodo de esgoto", foi publicada pela Environmental Protection Agency (EPA) em fevereiro de 1993 (Foess \& Sieger, 1993).

Esta legislação, basicamente cobre três categorias para a disposição final do L.E.: aplicação no solo (abrangendo aplicação na agricultura, em jardins, florestas e em áreas degradadas), disposição no solo (sem finalidade de fertilização ou correção das características físico-químicas), e a incineração do L.E. Não se incluem a co-disposição e/ou incineração do L.E. com outros materiais. Estão sujeitas a esta legislação as estações de tratamento de esgoto públicas e privadas, assim como qualquer pessoa que utilizar ou dispuser o L.E. gerado por estas estações (Goldstein, 1993). 
Segundo Donovan (1993), as características mais marcantes desta Lei foram: (a) a EPA coletou e analisou inúmeros dados sobre o L.E. que estava sendo gerado e a forma como ele estava sendo disposto; (b) a EPA utilizou os caminhos de contaminação mais restritivos, ou seja, aqueles que dariam maior grau de confiabilidade. Foram estipulados L.E. de "qualidade excepcional" e, por fim foi definido que todos os Estados deveriam atingir padrões nacionais mínimos. Essa Lei também foi "auto-implementada", ou seja, independentemente de autorização e fiscalizações, todos os indivíduos que lidassem com L.E. deveriam segui-la.

Os contaminantes também foram incluídos na "503"; a Water Environmental Federation (WEF, 1993) destaca os metais pesados (arsênio, cádmio, cobre, chumbo, mercúrio, molibdênio, níquel, selênio e zinco) e os patógenos (coliformes fecais, ovos de helmintos e salmonellas). Além disso, a aplicação do L.E. deve ser feita de maneira a reduzir a atração de vetores de doença, como roedores e moscas.

LEGISLAÇÃO BRASILEIRA - O Brasil não possui ainda uma legislação específica para a disposição final do L.E., em especial para a aplicação na agricultura, em florestas e em áreas degradadas. Porém, existem uma série de leis e normas que devem ser respeitadas. É o caso da NBR 10.004 (Norma Brasileira Registrada) da Associação Brasileira de Normas Técnicas (ABNT). Ela é responsável pela classificação dos resíduos sólidos quanto aos seus riscos potenciais ao meio ambiente e à saúde pública (Rocha, 1998; Bidone, 1998).

De acordo com a referida Norma, Resíduos Sólidos são todos aqueles resíduos nos estados sólidos e semi-sólidos, que resultam da atividade da comunidade de origem: industrial, doméstica, hospitalar, comercial, de serviços, de varrição ou agrícola. Incluise lodo de Estações de Tratamento de Esgoto (ETEs) e Estações de Tratamento de Água (ETAs), resíduos gerados em equipamentos e instalações de controle de poluição e líquidos que não possam ser lançados na rede pública de esgotos, em função de suas particularidades (ABNT, 1997).

Além da ABNT, outro órgão a ser consultado a respeito de normas e leis para a disposição final do L.E., é a Companhia de Tecnologia de Saneamento Ambiental (CETESB). Segundo esta entidade, o "transporte de lodo proveniente de unidades de 
tratamento de água, esgotos ou de efluentes líquidos industriais" devem ser licenciados segundo os memorandos 138/94 M e 227/94/I. O memorando 138/94 M apresenta uma lista de exigências técnicas a serem respeitadas para o licenciamento de empreendimentos de coleta, transporte e disposição do lodo (CETESB, 1997).

As observações utilizam as considerações da NBR-10.004, visando o enquadramento de lodo de ETEs e ETAs na conceituação de "biossólido" (Bidone, 1998). No estabelecimento de procedimentos para a utilização agrícola de biossólido no Estado de São Paulo a seguinte definição foi adotada: Biossólido é o resultado do sistema de tratamento biológico de despejos líquidos o qual foi processado de modo a poder ser manuseado de forma segura para utilização do seu valor como um nutriente, condicionador do solo, produção de energia ou outra utilização benéfica sem apresentar riscos à saúde humana ou animal (Straus \& Neto, 1998; Poggiani et al., 2000).

A aplicação agrícola de L.E. depende de um eficiente controle sobre a chegada de efluentes industriais na rede coletora afluente à ETE. A Companhia de Saneamento Básico do Estado de São Paulo (SABESP) e a Companhia de Saneamento do Paraná (SANEPAR), tem trabalhado para estabelecer critérios de uso agrícola do L.E.

O L.E. produzido no Brasil já vem sendo disposto de diversas maneiras: (a) disposição em aterros-ETE de Barueri, São Paulo; (b) aplicação na agricultura-Distrito Federal e Paraná. A fím de garantir que as formas para a disposição atualmente utilizadas não venham a prejudicar o meio ambiente e o homem, a CETESB e a SABESP, desenvolveram e aprovaram um Manual Técnico redigido na forma de Norma, complementando os critérios para a elaboração de projetos, implantação e operação de sistemas de aplicação de L.E. de sistemas de tratamento biológico em áreas de uso agrícola, visando atendimento de exigências ambientais. Este projeto de Norma (Aplicação de lodo de sistemas de tratamento biológico em áreas agrícolas - Critérios para projeto e operação - P 4.230), foi adaptado da norma 40 CFR (Code of Federal Regulations) Part 503 da U.S.EPA, de normas utilizadas nos Estados Unidos (Estados da Carolina do Norte e da Carolina do Sul) e de recomendações alemãs (CETESB, 1999; Straus, 2000). 


\subsubsection{Efeito do lodo de esgoto (biossólido) sobre a produtividade florestal}

As alternativas mais usadas para o aproveitamento e/ou destino final do L.E. têm sido: uso agrícola, incineração, disposição em aterros sanitário, reutilização industrial (fonte de energia) e disposição oceânica (Tsutya, 2000). Este mesmo autor cita o uso em florestas como uma alternativa junto às culturas agrícolas mais recomendadas (milho, trigo, cana-de-açúcar e sorgo).

O setor florestal brasileiro dispõe de poucas experiências técnico-científicas relativas ao uso do biossólido, de origem urbana ou industrial, como fertilizantes orgânicos em plantações de eucaliptos. Já o uso de resíduos orgânicos na fertilização de povoamentos de eucaliptos vem sendo praticado em algumas empresas florestais, como forma de aumento de produtividade das espécies e diminuição de custos com o manejo dos resíduos produzidos (Faria, 2000).

A adição de biossólido ao solo propicia um melhor aproveitamento de nutrientes pela planta, visto que são liberados gradativamente e podem atender às exigências nutricionais no decorrer do ciclo biológico (Guedes \& Poggiani, 1999).

Esse potencial agronômico do biossólido está fundamentalmente nos elevados teores de carbono orgânico presentes na sua composição. Aumenta o teor de carbono orgânico do solo podendo significar melhorias em suas propriedades físicas, químicas e biológicas. Além disso, esse resíduo apresenta em sua composição, apreciáveis quantidades de nutrientes, com destaque para o nitrogênio e fósforo. No entanto, não se deve dispensar inicialmente uma complementação com fertilizantes minerais, para compensar essa mineralização gradual (Vlawis \& Willians, 1971), principalmente, do elemento potássio, que, de maneira geral, existe em baixas concentrações nos biossólidos.

Diversos experimentos realizados no Estado de Washington (EUA), indicam que a aplicação de biossólido beneficia os sítios florestais, tendo contudo um resultado imediato que pôde ser constatado pelo crescimento das árvores e da vegetação do subbosque e, a longo prazo, pelo aumento da produtividade do sítio (Henry et al., 1994). 
Harrison et al., (1994) observaram o aumento na concentração de nutrientes na zona radicular de um solo florestal, perdurando por mais de 15 anos após aplicação do biossólido, garantindo desta forma a manutenção de nutrientes nas folhas refletindo assim uma boa produtividade.

Henry et al., (1993) conduziram estudos durante 20 anos em uma floresta experimental localizada em Washington (EUA), confirmando a grande potencialidade do biossólido para aumentar a produtividade de áreas florestais. Esses estudos mostraram claramente que a aplicação de biossólido, em taxas ambientalmente aceitáveis, resultam em elevadas taxas de respostas do crescimentos tanto para plantios jovens como para áreas bem estabelecidas. A resposta do crescimento à aplicação do biossólido é, tipicamente maior e mais duradoura quando comparada com fertilização química.

Zabowski \& Henry (1994) testaram também no Estado de Washington (EUA), em floresta madura de Pinus ponderosa, a aplicação de biossólido como fonte de nitrogênio $(N)$ para as plantas. Eles compararam a utilização de $11 \mathrm{tha}^{-1}$ de lodo (240 kg de $\mathrm{N}$ disponível ha ${ }^{-1}$ no primeiro ano) com a utilização de uréia e sulfato de amônio aplicados numa taxa de $220 \mathrm{~kg} \mathrm{~N} \mathrm{ha}^{-1}$. Todos fertilizantes aumentaram a extração de $\mathrm{N}$ no solo no primeiro ano após aplicação, aumentando também a concentração de $\mathrm{N}$ foliar, enquanto que o biossólido continuou promovendo esse aumento durante 5 anos, causando os maiores níveis de $\mathrm{N}$ foliar nas plantas.

No Brasil, os estudos com biossólido são tão recentes, quanto a preocupação com o tratamento dos esgotos. Oliveira (2000) em um trabalho de pesquisa, realizou uma vasta revisão bibliográfica citando os primeiros trabalhos exaltando o potencial de uso agrícola do biossólido (Bettiol et al., 1982; Melo et al., 1994; Deschamps \& Favaretto, 1997). Daí para frente, um número maior de trabalhos científicos interessados em estudar o comportamento do biossólido foram realizados, sendo dada também atenção ao uso no setor florestal. Para isto, trabalhos foram elaborados pelo Instituto de Pesquisas e Estudos Florestais (IPEF) em parceria com a SABESP. Devido à amplitude do ensaio, que abrange aspectos silviculturais e ambientais, foi agregada também uma 
equipe multidisciplinar de pesquisadores da Escola Superior de Agricultura "Luiz de Queiroz". Os trabalhos mais relevantes estão descritos na seqüência.

Vaz (2000) avaliou o efeito da aplicação de doses crescentes de biossólido $\left(5,10,15,20\right.$ e $40 \mathrm{tha}^{-1}$, base seca) na fertilidade do solo, crescimento e nutrição mineral de $E$. grandis em condições de campo num Latossolo Vermelho-Amarelo. Foi observado aumento dos teores de $\mathrm{K}$, Ca e $\mathrm{S}$ e redução das concentrações de $\mathrm{Al}$, Fe e $\mathrm{Mn}$, dependendo da dose de biossólido aplicado. Treze meses após aplicação do biossólido, foram constatados elevação do $\mathrm{pH}$ e considerável elevação dos teores de $\mathrm{P}, \mathrm{Ca}, \mathrm{K}$ e S na camada $0-5 \mathrm{~cm}$.

Os efeitos de doses crescentes de biossólido também foram testados sobre a nutrição, ciclagem de nutrientes e crescimento do sub-bosque, em uma plantação de $E$. grandis por Guedes (2000) a campo. O autor pode observar que o biossólido alterou o estado nutricional dos eucaliptos, exceto para o nutriente $\mathrm{Fe}$ e $\mathrm{Na}$. As plantas que receberam maior dose de biossólido $\left(40 \mathrm{tha}^{-1}\right)$ apresentaram maiores teores de $\mathrm{N}, \mathrm{P}, \mathrm{Ca}$ e depositaram $136 \%$ mais folhedo do que a testemunha e $40 \%$ a mais do que as plantas que receberam adubação mineral convencional e menor concentração de $\mathrm{Mn}$ e $\mathrm{Mg}$. O autor concluiu que a aplicação de biossólido em um povoamento jovem de $E$. grandis melhorou o estado nutricional das plantas, contribuiu para maior reciclagem biogeoquímica dos nutrientes dentro do ecossistema e não alterou o crescimento do subbosque.

Faria (2000) em um trabalho de pesquisa, apresentou uma estimativa da demanda do biossólido produzido na ETE de Barueri em plantações de eucalipto e determinou as produções mínimas de madeira que justificam economicamente o uso do biossólido como fertilizante. O estudo demonstrou que o consumo do biossólido, em torno da ETE de Barueri varia de 15 a $178 \mathrm{~km}$ com produção de 150 e $350 \mathrm{t} \mathrm{dia}^{-1}$ e doses de biossólido de 10 e $30 \mathrm{t} \mathrm{ha}^{-1}$. A avaliação econômica mostrou que a fertilização com biossólido com altos teores de umidade (60\%), pode apresentar limitações econômicas, sendo o elevado custo do transporte o principal fator. $\mathrm{O}$ autor salienta ainda que existe área de plantio de eucalipto em torno de Barueri suficiente para consumir toda a produção dessa ETE em distâncias de transporte economicamente viáveis. 


\subsubsection{Caracterização de biossólidos}

As características do biossólido irá depender da origem e do tipo de esgoto coletado, do seu grau e forma de tratamento e das características finais do lodo resultante na ETE. Segundo Tsutya (2000), existem três tipos de lodo oriundo do tratamento de esgoto: lodo primário (é o lodo bruto produzido nos decantadores primários, com odor ofensivo), lodo ativado (produzido nos reatores biológicos, com odor pouco ofensivo) e lodo digerido (que passa por processos de estabilização biológica, sem odor ofensivo).

Este mesmo autor cita ainda que para cada processo adotado nas ETEs, o lodo pode ser submetido a diferentes tipos de adensamento, estabilização, condicionamento e desidratação antes de sua disposição final. De modo geral, a estabilização é utilizada para a redução da massa, controle de odor e redução de microrganismos patogênicos, e o adensamento, o condicionamento, a desidratação e a secagem, são usadas para a remoção de água, redução do volume e possível redução da massa do lodo.

Raij (1998) cita que para fins agronômicos, a caracterização do biossólido deve ser realizada através de análise química completa e do teor de água ou do material sólido contido. O mais prático é apresentar o teor de matéria sólida total e os teores totais dos macronutrientes, nitrogênio e fósforo e dos metais pesados mais relevantes.

Quanto aos teores de nutrientes, o biossólido é rico em matéria orgânica, nitrogênio, fósforo, cálcio (proveniente principalmente do processo de tratamento) e micronutrientes que exercem um papel fundamental na manutenção da fertilidade do solo. A matéria orgânica contida no biossólido pode aumentar o conteúdo de húmus que melhora a capacidade de armazenamento e de infiltração da água no solo, aumentando a resistência dos agregados e reduzindo a erosão. Entretanto, o biossólido é deficiente em potássio, que, por ser um elemento muito solúvel, não fica retido na matéria orgânica do lodo (Andreoli \& Pegorini, 1998b).

As características do biossólido variam em função do local de origem, ou seja, de uma área tipicamente residencial ou industrial, da época do ano, do nível social da comunidade, do processo e do grau de tratamento de esgoto. Na Tabela 1 é apresentada a 
comparação dos principais parâmetros de valor agronômico dos biossólidos produzidos nas ETEs de diversas cidades do Brasil.

Tabela 1. Principais parâmetros de valor agronômico produzidos em diversas ETEs do Brasil (Tsutya, 2001).

\begin{tabular}{lccccccc}
\hline & \multicolumn{7}{c}{ Estação de Tratamento de Esgoto } \\
\cline { 2 - 8 } & Barueri & Franca & Suzano & Lavapés & Bertioga & Brasília & Belém \\
& (SP) & $(\mathrm{SP})$ & $(\mathrm{SP})$ & $(\mathrm{SJC})$ & (Bertioga $)$ & (Brasília) & (Curitiba) \\
\hline N total (\%) & 2,25 & 5,53 & 2,31 & 4,50 & 3,93 & 5,5 & 4,91 \\
F (\%) & 1,48 & 0,93 & 2,65 & 2,59 & 2,60 & 3,0 & 3,70 \\
K (\%) & 0,01 & 0,26 & 0,10 & 0,39 & 0,35 & 0,35 & 0,36 \\
M. O. (\%) & 44 & 65,2 & 41 & 52,6 & 68,3 & 52,5 & 69,4 \\
Ca (\%) & 7,29 & 2,0 & 14,6 & 13,3 & 1,30 & 4,5 & 1,59 \\
Mg (\%) & n.d & 0,22 & 0,22 & 0,27 & 0,37 & 0,35 & 0,60 \\
Zn (mg kg $\left.{ }^{-1}\right)$ & 990 & 1,560 & 2,705 & 682 & 437,8 & n.d. & n.d. \\
Cu (mg kg $\left.{ }^{-1}\right)$ & 348 & 160 & 543 & 120 & 136,0 & n.d. & n.d. \\
Fe (mg kg $\left.{ }^{-1}\right)$ & 15,117 & 11,995 & 40,454 & 10,461 & 66,622 & n.d. & n.d. \\
pH & 11 & 6,3 & 11,5 & 12,6 & 6,7 & 7,9 & 5,9 \\
\hline n.d - Não determinado & & & & & &
\end{tabular}

O biossólido, além de ser fonte de material orgânico e nutrientes, pode contribuir também para a contaminação do solo com metais pesados. Os metais pesados, dependendo da sua concentração, não apenas exercem efeitos negativos sobre o crescimento das plantas, mas também afetam os processos bioquímicos que ocorrem no solo. Os metais pesados, originários da atividade industrial, podem estar presentes nos biossólidos, pois as ETEs recebem os esgotos sanitários, que são compostos por esgoto doméstico, água de infiltração e esgoto industrial (Vanzo et al., 2001).

Para a aplicação do biossólido na agricultura ou em florestas, devem ser consideradas as concentrações máximas de metais pesados no biossólidos, as 
concentrações máximas de metais nos solos e as cargas cumulativas máximas de metais em solos pela aplicação do biossólido. Para a definição desses limites, os Estados Unidos basearam-se nas análises de risco, enquanto que a Comunidade Européia e o Canadá utilizaram o conceito de não degradação do solo e do meio ambiente (Tsutya, 2000).

A presença de metais pesados nos biossólidos depende de duas condicionantes básicas: representatividade dos lançamentos industriais em relação às vazões coletadas de origem doméstica e controle dos lançamentos industriais. A primeira refere-se à diluição de poluentes, independentemente da observância ou não da legislação que rege os lançamentos industriais. Para atender a segunda condicionante é de importância fundamental o controle de efluentes industriais, pois se o biossólido contiver metais pesados poluentes acima dos limites estabelecidos pela norma CETESB (1999), não poderá ser utilizado na agricultura, no estado de São Paulo (Tsutya, 2001).

Quanto aos agentes patogênicos, Fernandes (2000), cita que o lodo de esgoto possui uma grande variedade de microrganismos. A origem da contaminação microbiológica do lodo está ligada ao material fecal existente no esgoto, portanto, depende das características epidemiológicas da população local e dos efluentes lançados na rede coletora. No esgoto são encontrados quatro grupos de organismos patogênicos: fungos, vírus, bactérias e parasitas (protozoários e helmintos).

A norma norte americana EPA 40 CFR Part 503 recomenda onze processos de tratamento de lodo para a redução de patógenos, sendo seis processos que transformam o lodo em biossólido Classe A e cinco processos que geram o biossólido Classe B. Os processos são os seguintes: (i) Biossólido classe A: pode ser utilizado sem restrições, inclusive para horticultura. Ele deve apresentar as seguintes características sanitárias: teor de coliformes fecais menor que 1.000 NMP g ST${ }^{-1}$ (Número Mais Provável por grama de Sólidos Totais). (ii) Biossólido classe B: é de uso mais restrito, devendo ser aplicado em grandes culturas, reflorestamentos e outras situações onde o risco pode ser mais controlado. As exigências são: coliformes fecais inferior a $2 \times 10^{6} \mathrm{NMP}_{\mathrm{g} \mathrm{ST}}{ }^{-1}$ (CETESB, 1999; Tsutya, 2001). 


\subsection{O estudo de raízes finas das árvores}

\subsubsection{Classificação de raízes finas}

O sistema radicular de uma árvore pode ser dividido em duas classes de raízes: (i) raízes de absorção: caracterizado por raízes finas, não lenhosas, de vida curta e muitas vezes associada com fungos; (ii) raízes de sustentação: caracterizado por raízes mais espessas e suberificadas, de textura lenhosa e de vida longa.

Do ponto de vista funcional, as raízes de absorção são aquelas que apresentam intensa atividade metabólica, tendo como principal atribuição fisiológica a absorção de nutrientes e água. Já as raízes de sustentação, são aquelas responsáveis pelo suporte estrutural das árvores e também pela condução de soluções entre o sistema radicular e a parte aérea (Kramer \& Koslowski, 1979). A espessura das raízes é o critério mais utilizado para a classificação de raízes finas, principalmente em estudos sobre a avaliação da biomassa radicular. Na literatura, é possível encontrar o uso de $5 \mathrm{~mm}$ como limite superior da classe das raízes finas (Fogel, 1980; Meier et al., 1985).

Löhmus \& Ivask (1995) denominaram as raízes muito finas aquelas com diâmetro menor que $1 \mathrm{~mm}$. Ainda são mencionadas na literatura as raízes finíssimas do tipo "cabeleira", que se prolongam em regiões restritas do solo (ex.: acúmulo de matéria orgânica), as quais apresentam de 5 a $17 \mu \mathrm{m}$ de diâmetro (Sutton, 1980).

De acordo com trabalhos já desenvolvidos (Aber et al., 1985; Gonçalves, 1994; Mello, 1997), o critério fisiológico mais empregado na distinção da classe de raízes finas, considera aquelas que possuem diâmetro inferior a $3 \mathrm{~mm}$, não apresentando espessamento do xilema secundário e possuindo floema pouco desenvolvido.

A definição de classes de diâmetro permite interpretação de aspectos da dinâmica populacional de raízes finas, como a taxa de renovação e outros aspectos inerentes à ciclagem de nutrientes. 


\subsubsection{Distribuição de raízes finas}

Segundo Anghinoni \& Meurer (1999), a distribuição das raízes no perfil do solo segue uma forma característica de cada espécie. De maneira geral, dois padrões de distribuição são encontrados: o da estrutura típica de "árvore invertida", de um sistema de raiz primária, e o da estrutura tipo de "guarda chuva", de um sistema de raízes secundárias.

A forma, a profundidade e a distribuição lateral das raízes dependem de vários fatores, onde podem ser incluídos: o tipo de solo, teor de água e nutrientes no solo, aeração, tipo da floresta, quantidade de material orgânico e compactação (Vogt et al., 1981; Jordan, 1985; Sanford \& Cuevas, 1996). Todos esses fatores interagem com as características intrínsecas, ou seja, o genótipo da espécie, resultando numa arquitetura radicular única para cada árvore. Leles (1995) destaca ainda que injúrias e impedimentos físicos no solo podem dificultar a plena expressão deste material genético, promovendo alterações na distribuição das raízes no perfil do solo, podendo comprometer a produtividade, ou levar à morte do indivíduo.

De acordo com Barber (1995), a estrutura adensada do solo restringe o crescimento de raízes em profundidade, onde a maior parte das raízes, (sistema de raiz primária e sistema de raízes secundárias), normalmente se concentram na camada superficial de 0 a $15 \mathrm{~cm}$, sendo esta a camada mais importante para o suprimento de nutrientes para as plantas.

Reis et al., (1985) estudando o crescimento de Eucalyptus grandis em dois sítios, em Bom Despacho (sítio de boa qualidade) e Carbonita (sítio de pior qualidade), determinam que a maior participação de raízes na biomassa total da planta foi observada no sítio de pior qualidade ( $31,5 \%$ de raízes, ao 67 meses de idade), quando comparado com sítio de melhor qualidade ( $12,7 \%$ aos 73 meses de idade), e comentam ainda que a densidade de raízes finas diminui com a profundidade no perfil do solo.

A maior parte dos estudos envolvendo o sistema radicular de absorção das árvores, destaca sua concentração nos primeiros $30 \mathrm{~cm}$ de profundidade (Kramer \& Kozlowski, 1979; Vogt et al., 1981; Persson, 1983; Jordan, 1985; Gonçalves, 1994; 
Leles, 1995; Mello, 1997), isto depende, fundamentalmente, das condições de aeração e fertilidade do solo.

Badwill \& Stewart (1987) observaram em plantações de Eucalyptus grandis, que $77 \%$ das raízes com diâmetro maior que $1 \mathrm{~mm}$, foram encontradas nos primeiros $30 \mathrm{~cm}$ no perfil do solo. Até aquela profundidade, raízes menores que $1 \mathrm{~mm}$ de diâmetro chegaram a contribuir com $85 \%$ do volume total de raizes, mas apenas 3,5\% do peso.

Ao avaliar as características do sistema radicular de povoamento de Eucalyptus grandis em diferentes tipos de solos, Gonçalves (1994) encontrou maior densidade de raízes finas nos solos menos férteis; contudo, a distribuição de raízes ao longo do perfil do solo não foi diferente entre os diferentes solos, registrando cerca de $60 \%$ nos primeiros $30 \mathrm{~cm}$.

Mello (1997) caracterizando a distribuição das raízes finas no perfil do solo no verão e inverno, em diferentes genótipos de Eucalyptus, observou que os genótipos menos produtivos tendem a ter maior quantidade de raízes finas nas camadas superficiais do solo e na serapilheira, principalmente no verão.

O conhecimento sobre a formação e distribuição das raízes no perfil do solo é fundamental na busca de uma harmoniosa relação entre o sistema radicular e as intervenções realizadas no solo.

\subsubsection{Produção e renovação de raízes finas}

A entrada de nutrientes e matéria orgânica no solo via reciclagem radicular é considerada como um importante fator para a manutenção da fertilidade do solo (Lehmann \& Zech, 1998).

Segundo Reis et al. (1987), a alocação de nutrientes para o sistema radicular é relevante em estudos de ciclagem de nutrientes de Eucalyptus $s p$ dada a sua capacidade de regeneração por cepas, ou seja, o sistema radicular já estabelecido é também um componente das rotações subseqüentes e suas reservas são parcialmente utilizadas no desenvolvimento inicial da brotação. 
As raízes finas representam a porção mais dinâmica da biomassa subterrânea e respondem por uma significativa proporção da produção líquida primária (Santoantonio et al., 1977; Vogt et al., 1986; Cuevas et al., 1991), tanto em ecossistemas naturais como em culturas. Esta proporção varia com o tipo de vegetação, estágio de desenvolvimento, condições de solo, climáticas e práticas culturais (Salcedo et al., 1999).

Embora as raízes finas sejam as mais importantes na absorção de água e nutrientes, sua biomassa tem contribuição pequena em relação à extensão e superfície radicular (Gonçalves, 1994). Este mesmo autor, numa avaliação global dos dados existentes na literatura, estimou que a biomassa de raízes finas, com diâmetro $\leq 5 \mathrm{~mm}$ e para povoamentos florestais com menos de 10 anos, oscila entre 3 a $10 \mathrm{tha}^{-1}$.

O crescimento das raízes de muitas árvores, exibe um período de máxima atividade na primavera e no outono, quando os níveis de umidade e temperatura são especialmente favoráveis. As raízes reduzem sua atividade durante os períodos de seca e frio, declinando marcadamente no começo do inverno. Com baixas temperaturas no solo, a atividade metabólica tende a diminuir, reduzindo a permeabilidade da membrana de tal forma que a absorção de água e nutrientes seja limitada (Spur \& Barnes, 1982).

Existe também um ritmo diário de crescimento que se apresenta muito mais rápido durante a noite que durante o dia. Lyr \& Hoffman ${ }^{1}$, citados em Spur \& Barnes (1982), encontraram as seguintes porcentagens de maior crescimento noturno que diurno: chopo balsamífero (60\%), pinus silvestre (36\%) e pinabete da noruega (30\%).

Segundo Marshall \& Waring (1985), o tempo de sobrevivência das raízes é determinado pela quantidade de carboidratos nelas acumulados. Para Kramer \& Koslowski (1979), dentre os fatores ligados à senescência radicular incluem-se os hormonais, o balanço entre fotossíntese e respiração, a temperatura e umidade, os nutrientes, as pragas e doenças, etc.

De acordo com Bowen (1984), o gênero Eucalyptus geralmente apresenta um sistema radicular denso, com raízes muito finas e ramificadas que atuam como reservatório de nutrientes e que periodicamente é produzido ou destruído rapidamente.

\footnotetext{
${ }^{1}$ LYR, H.; HOFFMANN, G. Growth rates and growth periodicity of tree roots. International review of forestry reseach. v.2, p.181-236, 1967.
} 
$\mathrm{Na}$ época em que aumenta a disponibilidade de água e temperatura do solo, a produção de raízes é acelerada, suportando incrementos das taxas de crescimento da parte aérea.

Essa capacidade de produção e renovação de raízes das árvores contrasta marcadamente com a das plantas de ciclo de vida curto. Salcedo (1999) comenta que em sistemas de agricultura de subsistência, as raízes são a principal fonte de entrada de matéria orgânica no solo, pois a baixa produção de resíduos das culturas, seu uso alternativo e, em alguns casos, a queima da palha, reduzem outras entradas

Oades $^{2}$ citado por Salcedo (1999), observou que em ecossistemas naturais de regiões tropicais, as raízes finas também contribuem para a manutenção da matéria orgânica porque, enquanto a serapilheira é rapidamente mineralizada, os resíduos de raízes em contato direto com o solo mineral estão mais propensos a serem parcialmente estabilizados pela fase sólido coloidal.

A estabilização do crescimento radicular parece acompanhar a redução da taxa de crescimento da parte aérea (Gonçalves, 1994; Mello, 1997). Em povoamentos de Eucalyptus, a densidade máxima de raízes pode ocorrer quando a taxa de crescimento da parte aérea se estabiliza. Outros estudos indicam que o fechamento da copa coincide com a estabilização na produção de biomassa de raízes finas (Vogt et al., 1981; Berish \& Ewel, 1988). É neste período em que se inicia a competição principalmente por luz, particularmente no caso das espécies menos tolerantes ao sombreamento, como é o caso do Eucalyptus grandis.

Gonçalves (1994) cita que a renovação cíclica das raízes finas (morte e decomposição de raízes velhas e formação de raízes novas), provém um reservatório de material orgânico ao longo do perfil do solo, responsável pela maior fração da ciclagem de matéria orgânica e nutrientes, processo fundamental para a manutenção ou elevação do nível da fertilidade do solo.

${ }^{2}$ OADES, J.M. The retention of organic matter in soli. Biogeochemistry, v.5, p.35-70, 1988. 


\subsubsection{Método de estudo do sistema radicular}

Um grande número de trabalhos com as mais diversas culturas, nas diferentes regiões do mundo, utilizando os mais diversos métodos de estudo, tem sido desenvolvido para avaliar a distribuição do sistema radicular.

Em todos trabalhos estão envolvidos uma série de cuidados a fim de que os métodos utilizados possam representar, da melhor forma possível, a configuração real do sistema radicular. No entanto, o elevado gasto de tempo e energia utilizados nessa atividade, além das dificuldades para definir o método de estudo mais adequado para uma determinada situação (localidade, tipo de solo, cultura estudada, etc), são problemas comuns para todos os que estudam o sistema radicular em condições de campo.

Essas dificuldades encontradas no estudo de raízes foram enfatizados por Böhm (1979), já no prefácio de sua obra "Methods of Studying Root Systems", que reúne grande parte das técnicas para estudos em condições de campo da distribuição do sistema radicular no perfil do solo. Estas técnicas são: (i) método do monolito, (ii) método de escavação, (iii) perfuração com trado, (iv) método do perfil, (v) método da parede de vidro, (vi) método da sonda, e (vii) método indireto. Estes métodos foram amplamente detalhados em Gonçalves (1994) e Gonçalves \& Benedetti (2000).

$\mathrm{O}$ uso de sondas (tubos metálicos contendo uma ponteira apropriada com superfície cortante) de diversos diâmetros vem sendo empregado por muitos pesquisadores no estudo do sistema radicular de árvores. Consiste na retirada de amostras a diferentes profundidades e distâncias do tronco da árvore, após a qual as raízes são separadas do solo por meio de lavagem, fornecendo alguns parâmetros radiculares como peso, comprimento e diâmetro.

Este método permite intensificar os estudos do sistema radicular e seu monitoramento em povoamentos florestais, uma vez que possibilita coletar um grande número de amostras sem destruir a área experimental (Mello, 1997). Este mesmo autor, em um trabalho de pesquisa, verificou que este método funcionou bem para estudos sobre a distribuição de raízes finas no perfil do solo em povoamentos com diferentes materiais genéticos de eucalipto, amostrados em diferentes estações climáticas. A sonda 
com $4 \mathrm{~cm}$ de diâmetro interno mostrou-se adequada para as amostragens, especialmente para solos mais arenosos, em virtude da menor perda e deformação das amostras de solo com as raízes, além de representar ganhos operacionais de 30 a $50 \%$ superior aos obtidos com sonda de $8 \mathrm{~cm}$.

As variações do diâmetro das sondas, justificam também quanto aos usos particulares em cada trabalho, às condições do solo, disponibilidade de tempo e recursos. Böhm (1979), recomenda o emprego de sondas de $7 \mathrm{~cm}$ de diâmetro, com a qual uma amostragem com 5 repetições é suficiente.

McClaugherty et al. (1982) obtiveram resultados similares utilizando sondas de 19 e $50 \mathrm{~mm}$ de diâmetro, optando pelo uso da sonda de menor diâmetro, que demandou menor tempo e trabalho de processamento das amostras.

A partir de diferentes trabalhos, utilizando-se da amostragem com sondas na estimativa dos parâmetros radiculares, observa-se a dificuldade de equipará-los em função das diferentes metodologias empregadas para separar as raízes do solo, assim como outras limitações como: profundidade amostrada, estádio fisiológico do povoamento, idade, número de árvores por hectare, tamanho e classificação das raízes.

Os métodos de estudos de raízes finas apresentados na literatura são escassos e requerem um aperfeiçoamento e padronização para que se possa confiar nos resultados obtidos.

\subsection{Avaliação de parâmetros radiculares}

\subsubsection{Comprimento de raízes finas (Densidade)}

O comprimento de raízes é considerado um dos melhores parâmetros para estudos relativos à absorção de água e nutrientes (Böhm, 1979; Macduff, 1986; Delta T SCAN, 1993; Gonçalves, 1994; Mello, 1997). Estimou-se a densidade radicular (cm $\mathrm{cm}^{-3}$ ) pela divisão do comprimento radicular total encontrado nas amostras expresso em $\mathrm{cm}$, pelo volume de solo amostrado expresso $\mathrm{em} \mathrm{cm}^{-3}$. 


\subsubsection{Diâmetro de raízes finas}

O diâmetro médio das raízes de uma determinada espécie pode fornecer valiosas informações sobre o potencial de crescimento das raízes em solos onde se conhece bem as características de sua estrutura. Este parâmetro também é altamente relacionado com a área superficial ativa e volume de raízes (Gonçalves \& Benedetti, 2000).

\subsubsection{Superfície de raízes finas ou rizoplano}

A absorção de nutrientes pelas plantas no solo ocorre através do crescimento das raízes e por suas ramificações. A quantidade de nutrientes absorvidos é, então determinada pela área superficial total de raízes e pela taxa de absorção por unidade de superfície de raiz (Ansari et al., 1995). A taxa de absorção depende da cinética de absorção e a capacidade de suprimento de nutrientes pelo solo até a raiz. Desta forma, o significado da eficiência passa pelo entendimento da fisiologia da absorção (processos e mecanismos) e da morfologia (comprimento, raio, pêlos radiculares, etc) e distribuição do sistema radicular e suas interações com o solo (Anghinoni \& Meurer, 1999).

A superficie radicular mostra-se um dos principais parâmetros, representando a melhor relação com o potencial de absorção de água e nutrientes. A superfície radicular (S) foi calculada pressupondo que sua forma é cilíndrica, através da fórmula:

$$
S=\pi . T \cdot L_{s}
$$

Onde:

$\mathrm{S}=$ Superfície radicular

$\mathrm{T}=$ Diâmetro

$\mathrm{L}_{\mathrm{s}}=$ Comprimento total de raízes

O valor obtido foi dividido pelo volume de solo amostrado, e o resultado expresso em $\mathrm{cm}^{2} \mathrm{~cm}^{-3}$ de solo. 


\subsection{A luz em florestas e seu efeito sobre o crescimento das raízes}

Apesar dos fatores individuais do ambiente não serem forças isoladas que atuam sobre os organismos, a radiação solar é de fundamental importância como fonte essencial e direta de energia para o desenvolvimento e manutenção de qualquer forma de vida. A energia solar é a fonte da vida utilizada para a formação de toda a biomassa através da fotossíntese, que transforma a energia luminosa em química (Walter, 1971; Bazzaz, 1979; Spurr \& Barnes, 1982; Gardner et al., 1985).

Segundo Whatley \& Whatley (1982), a conversão de energia luminosa em química através da fotossíntese é o processo básico e necessário para o funcionamento, estrutura e sobrevivência de qualquer ecossistema que é fortemente dependente da luz.

A quantidade total de energia luminosa que atinge anualmente a terra é muito grande, mas muito pouco é diretamente usada pelas plantas. Da radiação solar que atinge as plantas, uma parte é absorvida, uma é refletida e outra parte é transmitida. Assim, a natureza e a qualidade da radiação solar recebida sobre a superfície da terra afeta a distribuição e o crescimentos da floresta (Spurr \& Barnes, 1982).

A quantidade de luz que atinge o solo de uma floresta depende das espécies presentes e da densidade das sucessivas camadas abaixo do dossel. Para Whatley \& Whatley (1982), a "captura de energia" ou a interceptação luminosa depende de uma superfície captadora (folhas), cujo tamanho e eficiência de transformação da energia luminosa em energia química depende da disponibilidade de nutrientes assegurada pelos processos de absorção (raízes finas) e reciclagem de nutrientes no sistema.

Bernardes (1987) e Larcher (2000) salientam que vários aspectos morfológicos (densidade da cobertura vegetal, distribuição horizontal das folhas, distribuição vertical entre folhas, ângulo foliar) e fisiológicos (idade da folha, tipo e tamanho da folha, flutuação na densidade e qualidade da luz, saturação luminosa), estão envolvidos na interceptação de luz pelas plantas. 
Para Whatley \& Whatley (1982), a forma das folhas e também seu ângulo de inclinação têm um importante papel nesta competição pela luz. Estas diferenças podem ser genéticas e permanentes ou ambientais e temporárias. A competição entre as folhas pela luz também resulta no desenvolvimento da folhas de "sol" e "sombra", que são encontradas em diferentes posições na mesma árvore.

A luz exerce grande influência sobre todos os estágios de desenvolvimento das plantas. Tanto a quantidade como a qualidade de luz são importantes para muitos processos fisiológicos nas árvores, como fotoperiodismo, fototropismo, dormência, alongamento caulinar, germinação de sementes e crescimento radicular (Whatley \& Whatley, 1982). A variação em qualquer destas características pode modificar o crescimento, tanto quantitativo como qualitativo (Kramer \& Kozlowski, 1979).

O estabelecimento e crescimento das plantas e do crescimento radicular depende da qualidade e da temperatura do solo, pois estes fatores influenciam o acúmulo de carbono, a absorção de água pelas plantas, a ciclagem dos nutrientes e a atividade radicular (Macduff et al., 1986; Domisch et al., 2001). As oscilações de temperatura no solo podem influenciar o desenvolvimento das raízes, acelerando ou reduzindo os processos metabólicos envolvidos (Sanford \& Cuevas, 1996).

As relações existentes entre as propriedades físicas, químicas e biológicas dos solos, juntamente com os fatores ambientais (temperatura ambiente, luz incidente, temperatura do solo e umidade), possuem uma relação direta com o crescimento da planta (Domisch et al., 2001), e a produtividade do sítio é amplamente determinada pelas propriedades do solo que influenciam na estrutura, distribuição e comportamento fisiológico das raízes (Gonçalves et al., 1990). 


\section{MATERIAL E MÉTODOS}

\subsection{Descrição da área experimental}

\subsubsection{Localização Geográfica}

A Estação Experimental de Ciências Florestais de Itatinga, administrado pela Escola Superior de Agricultura "Luiz de Queiroz", localiza-se no município de Itatinga, Estado de São Paulo (Figura 1), entre os paralelos $23^{\circ} 02^{\prime} 01^{\prime \prime}$ e $23^{\circ} 02^{\prime} 30^{\prime \prime}$ latitude Sul e os meridianos $48^{\circ} 38^{\prime} 34^{\prime \prime}$ e $48^{\circ} 37^{\prime} 30^{\prime \prime}$ longitude Oeste de Greenwich, com altitude média de $830 \mathrm{~m}$.

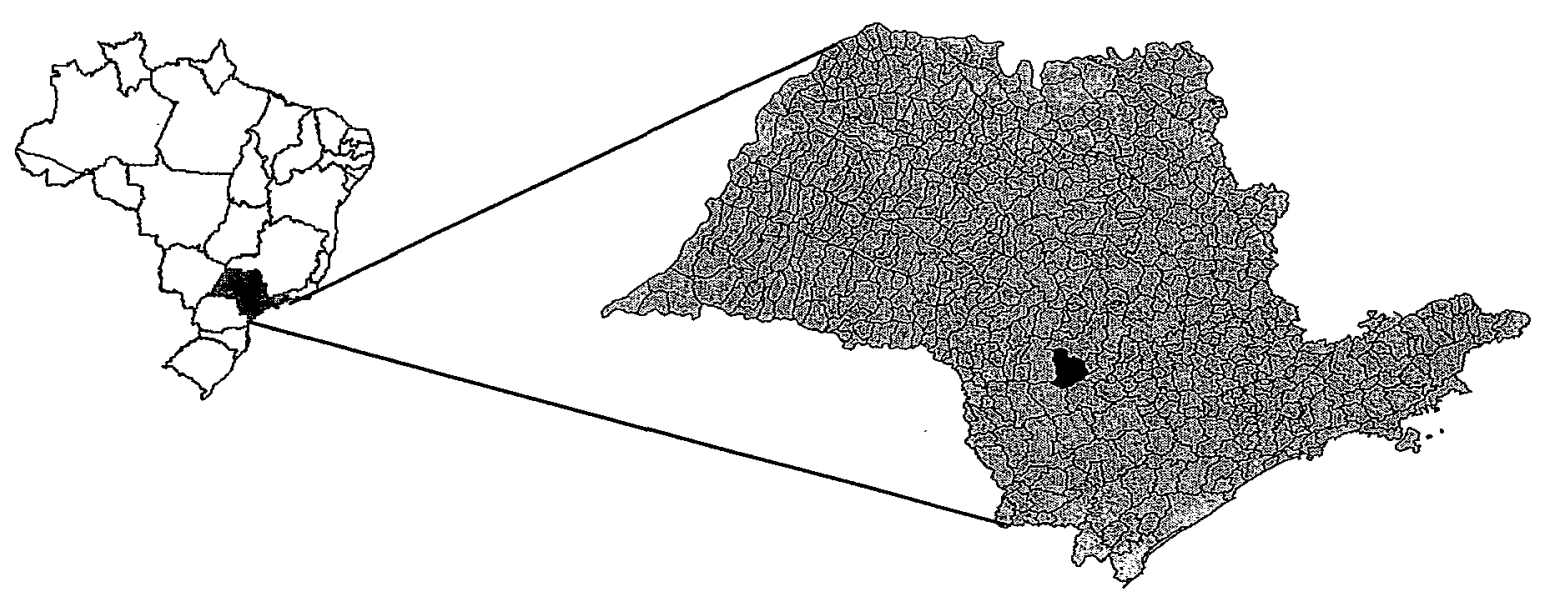

Figura 1 - Localização do município de Itatinga, Estado de São Paulo. 


\subsubsection{Histórico e Vegetação}

Tendo sido um Horto da FEPASA, a Estação Experimental de Itatinga apresenta alguns remanescentes de vegetação primitiva de cerrado, sendo predominante a cobertura florestal com povoamentos de Eucalyptus saligna Smith.

O plantio na Estação Experimental (aproximadamente 2200 ha), teve início no ano de 1945, sendo feito em talhões retangulares, medindo aproximadamente $500 \times 350$ m como é mostrado na Figura 2.

A área onde foi desenvolvida a pesquisa, é um povoamento jovem de Eucalyptus grandis Hill ex Maiden, plantado no sistema de cultivo mínimo em fevereiro de 1998.

\section{$\mathrm{N}$}

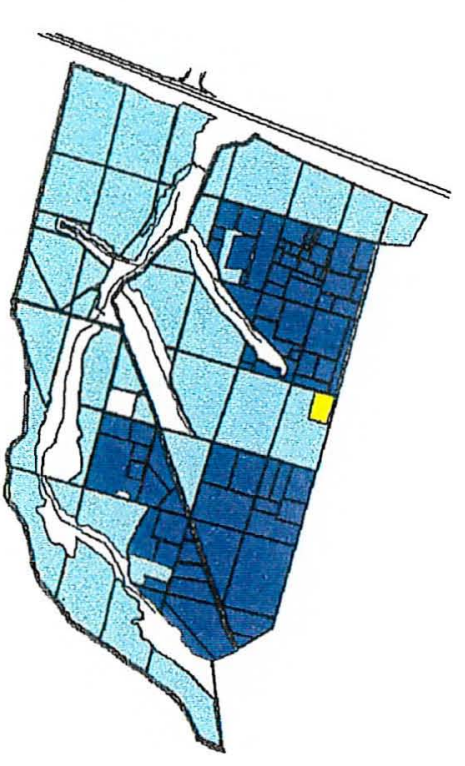

\section{Legenda}

Área experimental da Estação

Área de produção da Estação

Talhão experimental com Biossólido

Figura 2 - Localização das áreas experimentais e de produção na Estação Experimental de Itatinga, Estado de São Paulo. 


\subsubsection{Clima}

O clima da região de acordo com a classificação de Köppen é do tipo Cwa: mesotérmico úmido com inverno seco, com precipitação média mensal do mês mais seco entre 30 e $60 \mathrm{~mm}$, com média mensal da temperatura mínima de $8^{\circ} \mathrm{C}$ e média mensal da temperatura máxima de $36^{\circ} \mathrm{C}$.

Durante os 36 meses desde o início do período experimental, a precipitação média anual foi de $1167 \mathrm{~mm}$, a média das temperaturas mínimas foi de $14^{\circ} \mathrm{C}$ e das máximas $28^{\circ} \mathrm{C}$. A umidade relativa média mensal foi de $85 \%$. Não houve déficit hídrico.

$\mathrm{Na}$ Figura 3 são apresentados os dados climáticos coletados no posto meteorológico situado na Estação Experimental desde a implantação do experimento.

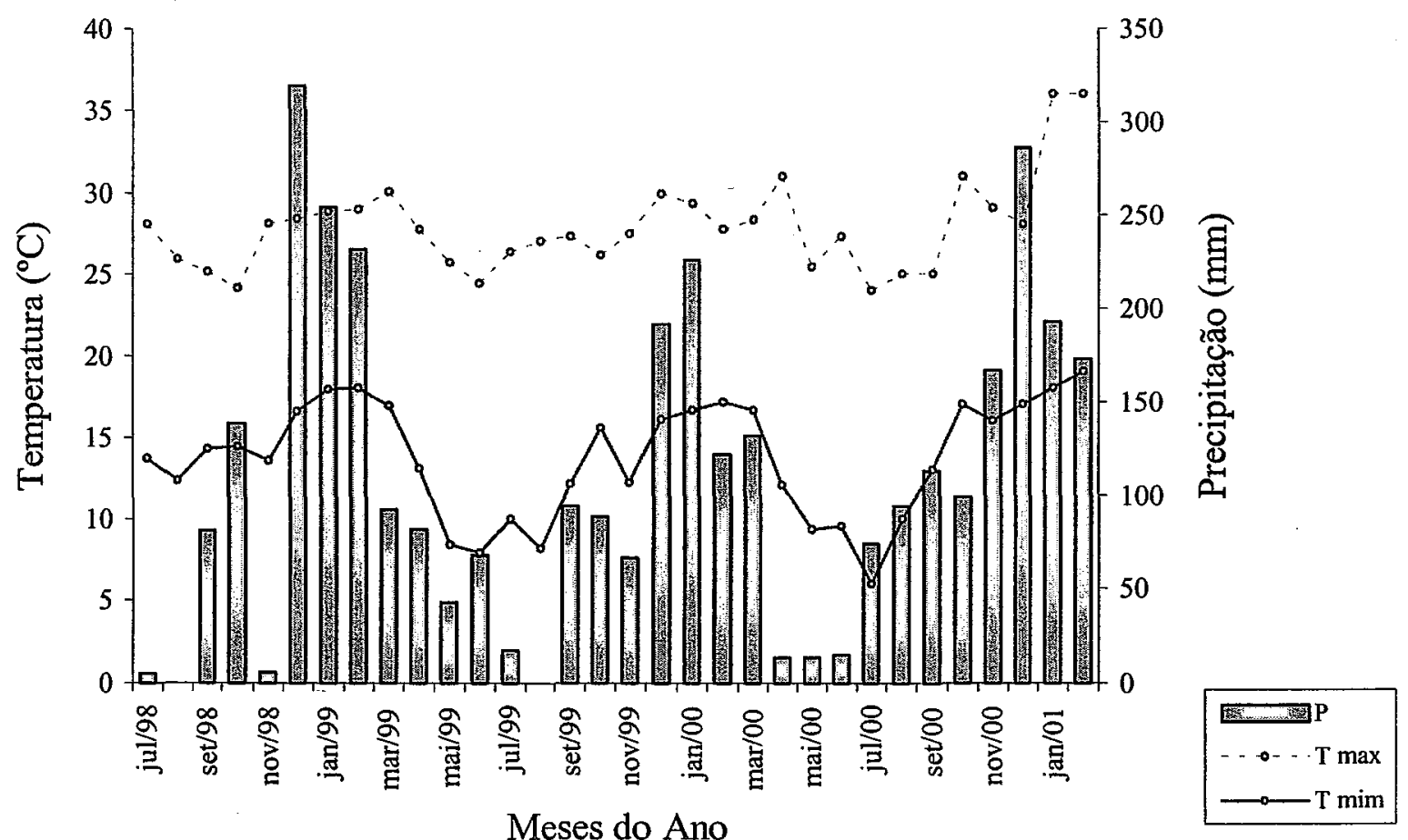

Figura 3 - Médias mensais das temperaturas máximas (T max.) e temperaturas mínimas (T min.) e valores de precipitação pluviométrica (P), no período de julho de 1998 a fevereiro de 2001. 


\subsubsection{Solo}

A área de estudo está localizada sobre um Latossolo Vermelho-Amarelo textura média distrófico (areia $=830$, silte $=50$ e argila $=120 \mathrm{~g} \mathrm{~kg}^{-1}$ na camada $0-20 \mathrm{~cm}$ ). São solos com profundidades superiores a 2 metros, bem drenados apresentando baixa capacidade de troca catiônica formados a partir de arenitos, cujas características químicas e físicas são apresentadas na Tabela 2. O relevo é composto por topos aplainados e encostas de formas retilínea ou convexas, apresentando declividade entre 10 e $15 \%$ (Pessotti, 1994).

Tabela 2. Principais características química e física do Latossolo Vermelho-Amarelo da área experimental segundo Vaz (2000).

\begin{tabular}{|c|c|c|c|c|c|c|c|c|c|c|c|c|}
\hline Prof. & $\mathrm{pH}$ & $\mathrm{MO}$ & $P$ & $\mathrm{~K}$ & $\mathrm{Ca}$ & $\mathrm{Mg}$ & $\mathrm{H}+\mathrm{Al}$ & $\mathrm{Al}$ & SB & $\mathrm{T}$ & \multirow{2}{*}{$\begin{array}{l}\mathrm{V} \\
\%\end{array}$} & \multirow{2}{*}{$\frac{\mathrm{m}}{\%}$} \\
\hline $\mathrm{Cm}$ & & $\mathrm{g} \mathrm{dm}^{-3}$ & $\mathrm{mg} \mathrm{dm}^{-3}$ & \multicolumn{7}{|c|}{ 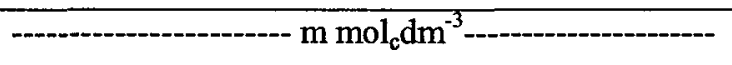 } & & \\
\hline $0-5$ & 3,6 & 56 & 2 & 0,9 & 3 & 2 & 92 & 19 & 6 & 97 & 5 & 79 \\
\hline $5-10$ & 3,8 & 18 & 1 & 0,9 & 2 & 2 & 53 & 12 & 5 & 59 & 10 & 68 \\
\hline \multirow[t]{2}{*}{$10-20$} & 3,8 & 15 & 1 & 0,9 & 4 & 1 & 45 & 10 & 6 & 50 & 11 & 65 \\
\hline & & $\mathrm{Cu}$ & $\mathrm{Zn}$ & \multicolumn{2}{|c|}{$\mathrm{Mn}$} & \multicolumn{2}{|c|}{$\mathrm{Fe}$} & \multicolumn{3}{|c|}{$\mathrm{S}^{-\mathrm{So}_{4}}{ }^{2-}$} & \multicolumn{2}{|c|}{ B } \\
\hline \multicolumn{13}{|c|}{ n...- $\mathrm{mg} \mathrm{dm}^{-3}$} \\
\hline $0-5$ & \multicolumn{2}{|c|}{0,5} & 0,5 & \multicolumn{2}{|c|}{2,4} & \multicolumn{2}{|c|}{123} & \multicolumn{3}{|c|}{12,8} & \multicolumn{2}{|c|}{0,2} \\
\hline $5-10$ & \multicolumn{2}{|c|}{0,6} & 0,3 & \multicolumn{2}{|c|}{0,5} & \multicolumn{2}{|c|}{76} & \multicolumn{3}{|c|}{13,9} & \multicolumn{2}{|c|}{0,2} \\
\hline $10-20$ & \multicolumn{2}{|r|}{0,7} & 0,3 & \multicolumn{2}{|c|}{0,4} & \multicolumn{2}{|c|}{67} & \multicolumn{3}{|c|}{26,6} & \multicolumn{2}{|c|}{0,2} \\
\hline \multirow{2}{*}{\multicolumn{2}{|c|}{ Prof. }} & \multicolumn{6}{|c|}{ Areia } & \multirow{2}{*}{\multicolumn{3}{|c|}{ Silte }} & \multicolumn{2}{|c|}{ Argila } \\
\hline & & \multicolumn{2}{|c|}{ Grossa } & Fin & & \multicolumn{2}{|c|}{ Total } & & & & & \\
\hline \multicolumn{2}{|c|}{$\mathrm{cm}$} & \multicolumn{11}{|c|}{ 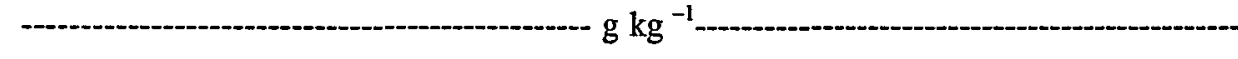 } \\
\hline \multicolumn{2}{|c|}{$0-30$} & \multicolumn{2}{|c|}{532} & 241 & & & 73 & & 59 & & & \\
\hline 30 & & & & 266 & & & 61 & & 49 & & & \\
\hline & & & & 278 & & & 74 & & 29 & & & \\
\hline
\end{tabular}

*Análise segundo metodologia apresentada por Raij et al. (1987).

**Análise segundo metodologia apresentada por Camargo et al. (1986). 


\subsection{Metodologia}

\subsubsection{Delineamento experimental e tratamentos}

O experimento foi conduzido num delineamento em blocos casualizados, com 9 tratamentos e 4 repetições. Cada parcela experimental é constituída por 100 plantas, ou seja, 10 linhas com 10 plantas cada. Somente 36 plantas centrais foram consideradas nas avaliações dendrométricas e, as demais deixadas como bordadura dupla. A espécie florestal utilizada foi o Eucalyptus grandis Hill Ex Maiden, procedente de Coff's Harbour, Austrália. O plantio com mudas formadas a partir de sementes foi realizado em fevereiro de 1998, utilizando espaçamento de 3,0 m entrelinha e 2,0 $\mathrm{m}$ na linha de plantio. As doses crescentes de biossólido aplicadas nos diferentes tratamentos foram distribuídas conforme a relação a seguir e exposta por Vaz (2000).

1. Testemunha "Tt" - Sem fertilização mineral e sem aplicação de biossólido;

2. Adubação mineral "Ad" - $1,5 \mathrm{t} \mathrm{ha}^{-1}$ de calcário dolomítico (a lanço na área total), $110 \mathrm{~kg} \mathrm{ha}^{-1}$ de adubo N-P-K 0-45-0 (sulco de plantio), $150 \mathrm{~kg} \mathrm{ha}^{-1}$ de 10-20-10 (sulco de plantio), $80 \mathrm{~kg} \mathrm{ha}^{-1}$ de 20-0-20 (45 dias pós-plantio aplicado em meia lua próximo à muda), $180 \mathrm{~kg} \mathrm{ha}^{-1}$ de 16-0-32 + 0,3\% Boro $+0,5 \%$ de Zinco (6 meses pós-plantio aplicado numa faixa de $40 \mathrm{~cm}$ na entrelinha de plantio) e $240 \mathrm{~kg} \mathrm{ha}^{-1} \mathrm{de}$ 16-0-32 + 0,3\% Boro + 0,5\% de Zinco (12 meses pós-plantio aplicado numa faixa de $40 \mathrm{~cm}$ na entrelinha de plantio);

3. $5 \mathrm{tha}^{-1}$ de biossólido, complementado com Potássio;

4. $10 \mathrm{t} \mathrm{ha}^{-1}$ de biossólido, complementado com Potássio "10t + K";

5. $10 \mathrm{t} \mathrm{ha}^{-1}$ de biossólido, sem complemento de Potássio;

6. $10 \mathrm{t} \mathrm{ha}^{-1}$ de biossólido, complementado com Potássio e Fósforo "10t + KP";

7. $15 \mathrm{t} \mathrm{ha}^{-1}$ de biossólido, complementado com Potássio;

8. $20 \mathrm{t} \mathrm{ha}^{-1}$ de biossólido, complementado com Potássio " $20 \mathrm{t}+\mathbf{K}$ ";

9. $40 \mathrm{t} \mathrm{ha}^{-1}$ de biossólido, complementado com Potássio " $40 \mathrm{t}+\mathrm{K}$ ". 
Os tratamentos $3,4,6,7,8$ e 9 receberam suplementação de potássio $(\mathrm{KCl}, 60 \%$ de $\mathrm{K}_{2} \mathrm{O}$ ), até que as quantidades de potássio contidas no biossólido somadas às do fertilizante potássico ficassem iguais à do tratamento $2\left(125 \mathrm{~kg} \mathrm{ha}^{-1} \mathrm{de} \mathrm{K}\right) . \mathrm{O}$ tratamento 6 recebeu a mesma dose de fósforo (superfosfato triplo) que o tratamento $2(34,73 \mathrm{~kg}$ $\mathrm{ha}^{-1}$ de P). Em julho de 1998, foi feito a aplicação de biossólido, em faixas ( $2 \mathrm{~m}$ de largura), nas entrelinhas, $50 \mathrm{~cm}$ distante das linhas de plantio.

A suplementação de potássio foi feita parceladamente, em até três vezes. A primeira parcela de $\mathrm{KCl}, 35 \mathrm{~kg} \mathrm{ha}^{-1}$ de $\mathrm{K}_{2} \mathrm{O}_{5}$, foi aplicada em meia lua ao redor das plantas, seis meses após o plantio; a segunda, $58 \mathrm{~kg} \mathrm{ha}^{-1}$ de $\mathrm{K}_{2} \mathrm{O}_{5}$, aplicada em faixas de $40 \mathrm{~cm}$ de largura, no centro das entrelinhas, 12 meses após o plantio e a terceira parcela e o restante, foram aplicadas em faixas de $40 \mathrm{~cm}$ de largura, no centro das entrelinha, 18 meses após o plantio. O superfosfato usado no tratamento 6 foi aplicado no sulco de plantio.

Para este estudo do sistema radicular de absorção foram considerados apenas os tratamentos: 1) “Tt”; 2) “Ad"; 4) “10t+K"; 6) “10t+KP"; 8) “20t+K" e 9) "40t+K".

\subsubsection{Caracterização e aplicação do biossólido utilizado}

O material utilizado no experimento foi proveniente da Estação de Tratamento de Esgoto (ETE) da SABESP de Barueri, região metropolitana de São Paulo.

A SABESP foi responsável pela preparação e caracterização físico-química do lodo enviado, dentro do estabelecido pela norma norte americana 40 CFR Part 503 elaborada pela Agência de Proteção Ambiental dos Estados Unidos.

O biossólido aplicado na área experimental foi produzido após tratamento biológico dos esgotos seguido de condicionamento químico com cloreto férrico e cal $\left(\mathrm{FeCl}_{3}\right.$ e $\left.\mathrm{CaOH}_{2}\right)$ e desidratado na fase final. $\mathrm{O}$ material possuía densidade de coliformes fecais inferior a $2 \times 10^{6} \mathrm{NMP}_{\mathrm{g} \mathrm{ST}}{ }^{-1}$ (Número Mais Provável por grama de Sólidos Totais), sendo caracterizado como Biossólido tipo B (CETESB, 1999). Já que o processo de estabilização com cal é aceito pelo órgão controlador como eficiente na redução de patógenos, a densidade dos organismos indicadores ficou abaixo do limite máximo 
permitido.

Atualmente, a ETE de Barueri eliminou o condicionamento químico do processo de tratamento, passando a utilizar polímeros e produzir lodo com características distintas das apresentadas aqui. Na Tabela 3 é apresentada a composição do biossólido aplicado na área experimental.

Tabela 3. Característica do biossólido utilizado: elementos totais, base seca a $65^{\circ} \mathrm{C}$ produzido pela ETE Barueri, Guedes (2000).

\begin{tabular}{lclc}
\hline \multicolumn{1}{c}{ Elemento } & Concentração & \multicolumn{1}{c}{ Elemento } & Concentração \\
\hline $\mathrm{C}\left(\mathrm{g} \mathrm{kg}^{-1}\right)$ & 172,0 & $\mathrm{Cu}\left(\mathrm{mg} \mathrm{kg}^{-1}\right)$ & 900 \\
$\mathrm{~N}\left(\mathrm{~g} \mathrm{~kg}^{-1}\right)$ & 25,6 & $\mathrm{Fe}\left(\mathrm{mg} \mathrm{kg}^{-1}\right)$ & 39200 \\
Relação C:N & 4,3 & $\mathrm{Zn}\left(\mathrm{mg} \mathrm{kg}^{-1}\right)$ & 1500 \\
$\mathrm{P}\left(\mathrm{g} \mathrm{kg}^{-1}\right)$ & 9,5 & $\mathrm{Mn}\left(\mathrm{mg} \mathrm{kg}^{-1}\right)$ & 300 \\
$\mathrm{~K}\left(\mathrm{~g} \mathrm{~kg}^{-1}\right)$ & 1,3 & $\mathrm{Na}\left(\mathrm{g} \mathrm{kg}^{-1}\right)$ & 0,5 \\
$\mathrm{Ca}\left(\mathrm{g} \mathrm{kg}^{-1}\right)$ & 95,0 & $\mathrm{Cd}\left(\mathrm{mg} \mathrm{kg}^{-1}\right)$ & 21 \\
$\mathrm{Mg}\left(\mathrm{g} \mathrm{kg}^{-1}\right)$ & 3,0 & $\mathrm{~Pb}\left(\mathrm{mg} \mathrm{kg}^{-1}\right)$ & 200 \\
$\mathrm{~S}\left(\mathrm{~g} \mathrm{~kg}^{-1}\right)$ & 6,0 & $\mathrm{pH} \mathrm{em} \mathrm{CaCl}$ & 10,6 \\
\hline
\end{tabular}

A distribuição do biossólido na área experimental foi em julho de 1998, e para isso foi usada uma carreta com $3 \mathrm{~m}^{3}$ de capacidade puxada por um trator. $\mathrm{O}$ biossólido (60\% de umidade) foi aplicado à lanço em cobertura nas entrelinhas de plantio e mantendo aproximadamente uma distância de meio metro das mudas dos eucaliptos.

\subsubsection{Determinação da área basal}

A área basal é de fundamental importância para os modelos de crescimento e produção, estudos de densidade e principalmente no cálculo do volume por hectare. Neste contexto, a área basal é um dos parâmetros úteis na descrição de um povoamento, pois se relaciona diretamente ao diâmetro a altura do peito (d.a.p.). 
A quantidade de área basal estocada em um povoamento está entre outros fatores em função do clima e do solo. Quando os fatores climáticos se mantêm constantes, as propriedades do solo se convertem no fator principal do ambiente físico, que possui uma relação direta com o crescimento das raízes finas (Kramer \& Kozlowisk, 1979).

Os dados dendrométricos das árvores das parcelas experimentais foi realizado em janeiro de 2001, medindo-se o d.a.p. e a altura das árvores. A área basal $\left(\mathrm{m}^{2}\right)$ foi calculada pela fórmula:

$$
G=\frac{\pi}{4} \times d^{2}
$$

Onde:

$\mathrm{G}=$ Área basal

$\mathrm{d}^{2}=$ Diâmetro a altura do peito

\subsubsection{Estudo do microclima}

Segundo a ACIESP (1997), o microclima ou ecoclima corresponde ao clima na escala e no nível dos organismos. Representa portanto as condições climáticas que envolvem os organismos em estudo como, por exemplo, os estratos das copas, serapilheira, horizontes do solo, troncos, sistema radicular, etc. Na floresta, a energia radiante que chega no sub-bosque é atenuada pela presença das folhas. Quanto mais ampla a superfície foliar, menor a energia que chega no sub-bosque, afetando conseqüentemente a temperatura e a umidade do ar, a luminosidade e também a temperatura e a umidade do solo e conseqüentemente, o crescimento do sistema radicular das árvores. 


\subsubsection{Luz incidente no sub-bosque}

Para a coleta e registro dos valores de luz difusa no sub-bosque foi utilizado o PAR, que mede a radiação fotossinteticamente ativa (RFA) na faixa de 400 a $800 \mathrm{~nm}$.

Em cada tratamento foram realizadas 20 medidas internas, evitando sempre as áreas onde havia clareira causadas por árvores mortas. Apenas um PAR foi utilizado para obter os valores de luminosidade no sub-bosque, e desta forma as medidas externas e internas de cada tratamento foram tomadas com o mesmo instrumento.

O procedimento em campo consistiu na realização de uma medida externa, na área aberta, seguida das medidas internas em cada tratamento. Os valores de luminosidade coletados foram diretamente transcritos para uma planilha. As medidas em todos os tratamentos foram efetuadas no período das 13:00 às 14:30 horas do dia 9 de fevereiro, com céu sem nuvens.

\subsubsection{Temperatura do solo nos diferentes tratamentos}

Simultaneamente às medidas de energia luminosa, foram amostrados também os valores da temperatura do solo, utilizando-se um geotermômetro digital, com um sensor de aço inoxidável. Foram registradas 8 medidas da temperatura superficial e 8 medidas da temperatura a $10 \mathrm{~cm}$ de profundidade em cada tratamento.

\subsubsection{Coleta de raízes finas}

Para a amostragem das raizes finas ( $\leq 3 \mathrm{~mm}$ de espessura), foi utilizada uma sonda cilíndrica de aço inoxidável, com $4 \mathrm{~cm}$ de diâmetro interno com $80 \mathrm{~cm}$ de comprimento (Figura 4).

Foram selecionadas 4 árvores médias quanto ao diâmetro à altura do peito (d.a.p.) na área central de cada parcela experimental. Tendo como ponto de partida o tronco de 2 árvores, foram retiradas 3 amostras nas linhas de plantio e 3 amostras nas 
entrelinhas do plantio em intervalos de $0,50 \mathrm{~m}$. Foi dada uma atenção especial na escolha das árvores para evitar a presença de falhas, tocos e plantas daninhas nos pontos de coleta.

A distribuição das raízes finas no perfil do solo foi determinada tendo por base amostragens feitas nas camadas $0-10$ e $10-30 \mathrm{~cm}$ de profundidade. A amostragem foi realizada em fevereiro de 2001. As amostras retiradas da área experimental foram acondicionadas em sacos plásticos e mantidas sob refrigeração para evitar a dessecação e morte das raízes.

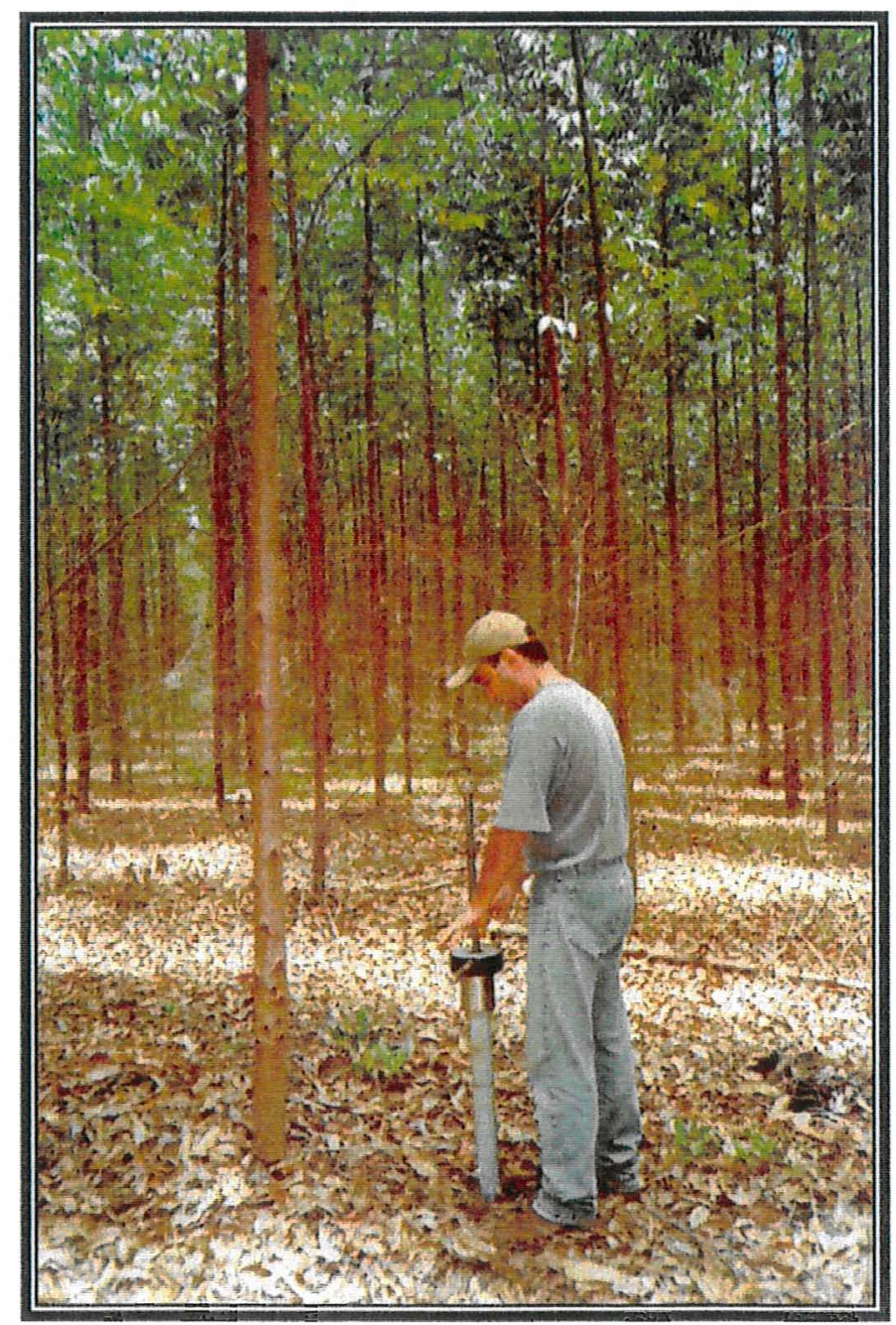

Figura 4 - Sonda de $4 \mathrm{~cm}$ de diâmetro com $80 \mathrm{~cm}$ de comprimento usada para amostragem de raízes finas. 


\subsubsection{Lavagem e separação de raízes finas}

Para a lavagem e separação das raízes finas, foi utilizado o lavador e separador de raízes Delta T Root Washer (Figura 5), baseado no "design" usado pelo Cunninghm Laboratory em Brisbane, Austrália, onde Kirchhof \& Pendar desenvolveram o lavador de raízes semi-automático com capacidade para grande volume de solo (Delta T, 1995).

As amostras de solo-raiz foram colocadas em baldes de $35 \mathrm{~cm}$ de altura por 30 $\mathrm{cm}$ de diâmetro. Através de 2 jatos de água com pressão entre 50 a 70 psi, a água é revolvida dentro do balde, a amostra é dispersada, separando o solo das raízes. As raízes e sedimentos de mesma densidade (mais leves que o solo), passam por um cano central com $11 \mathrm{~cm}$ de diâmetro e altura equivalente a do balde, onde ficam retidos num funil com $5 \mathrm{~cm}$ de diâmetro com uma malha de nylon $<0,1 \mathrm{~mm}$. Devido a natureza do solo, não foi necessário o uso de agentes dispersantes. Após a lavagem das amostras para a remoção das partículas de solo e material orgânico, as raízes finas $(\leq 3 \mathrm{~mm}$ de espessura) foram acondicionadas numa solução contendo $70 \%$ de álcool etílico, pois segundo Johansen (1940), este é um bom fixador da estrutura externa da raiz. Todo material (solo+raiz) não prontamente separado foi mantido sob refrigeração.

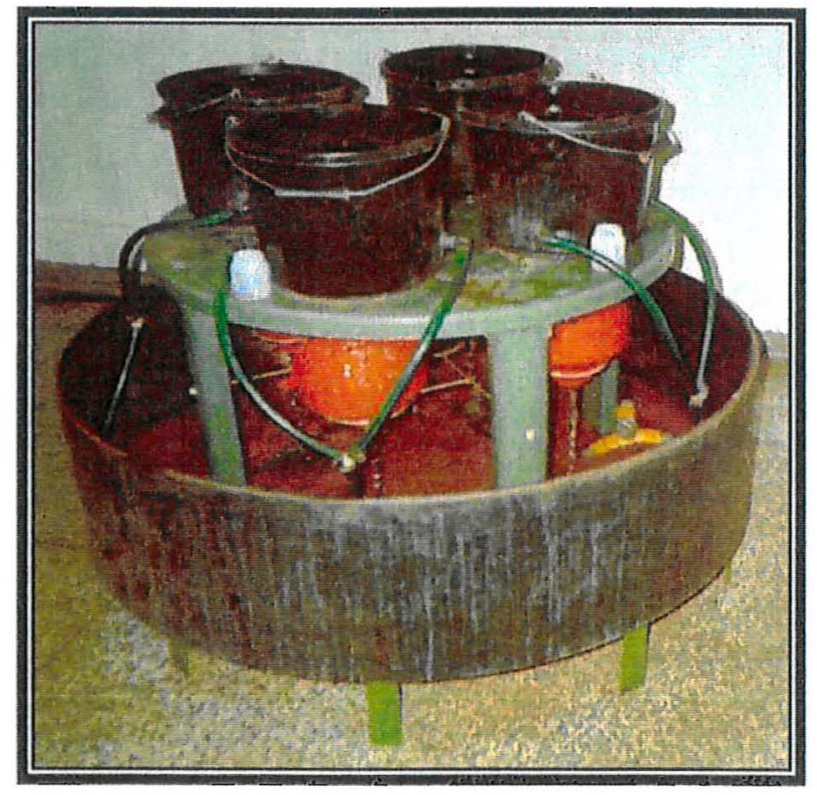

Figura 5 - Lavador e separador de raízes Delta T Root Washer. 


\subsubsection{Comprimento e diâmetro de raízes finas}

O comprimento total e o diâmetro médio das raizes finas com espessura $\leq 3 \mathrm{~mm}$, foram medidos pelo sistema Delta T SCAN Image Analysis Software (DELTA T SCAN, 1993).

As raízes foram distribuídas em uma bandeja de vidro de 36 x $23 \mathrm{~cm}$ e $3,5 \mathrm{~cm}$ de altura. Sobre estas, foi colocada uma lamínula do próprio álcool onde as raízes estavam armazenadas, suficiente para cobri-las. A bandeja foi colocada sobre um "scanner" de mesa com resolução de 400 dpi. As imagens das raízes obtidas pela varredura efetuada pelo "scanner" e transferidas automaticamente para um arquivo no computador, podem ser consideradas imagens já digitalizadas, prontas para o processamento do cálculo do comprimento total e diâmetro médio radicular (Figura 6).

O trabalho de digitalização de imagens assim como todo o trabalho de lavagem e separação das raízes finas foram realizados no Laboratório de plantas cultivadas sob condições de estresse do Departamento de Botânica da Escola Superior de Agricultura “Luiz de Queiroz" - Universidade de São Paulo. 


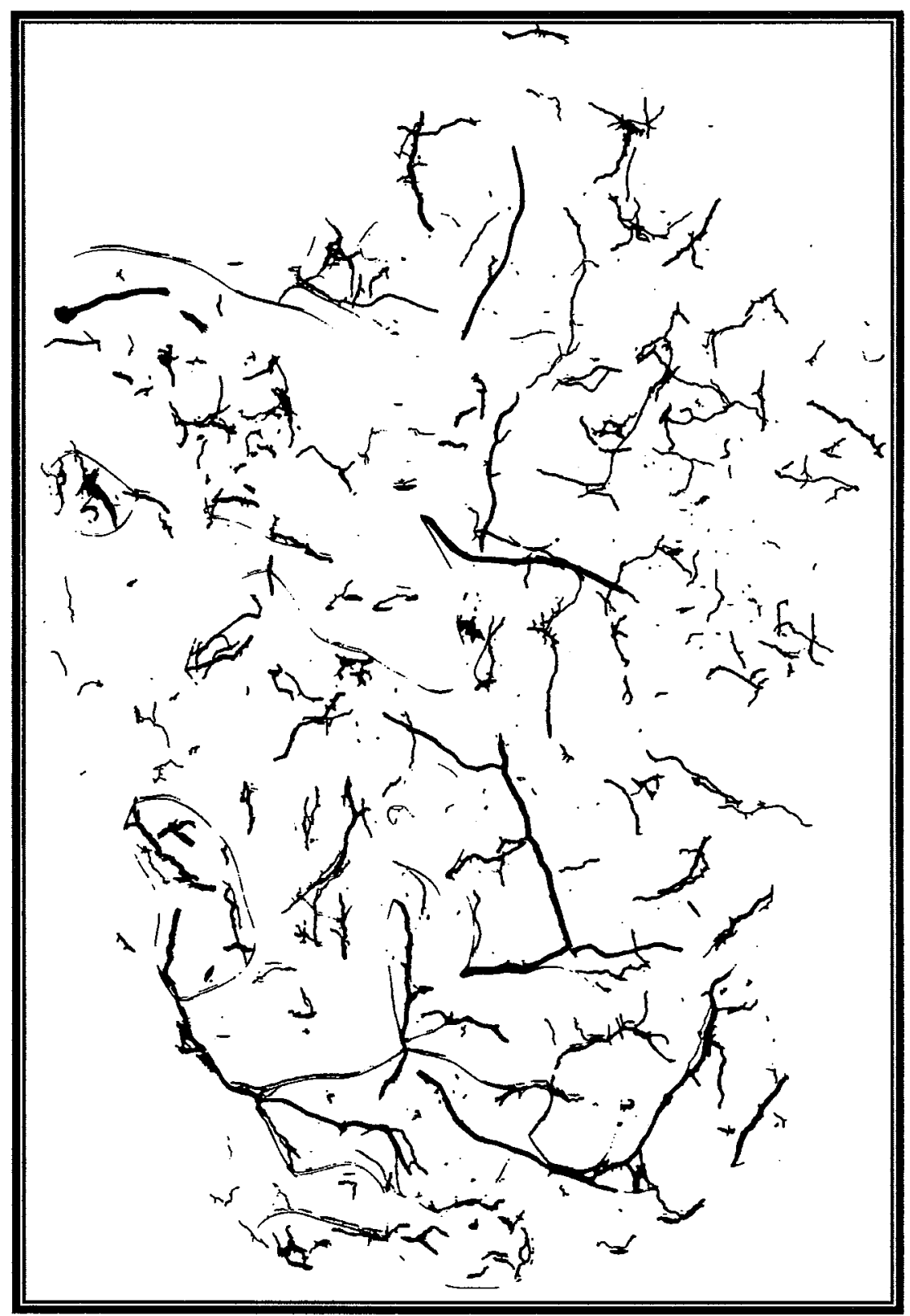

Figura 6 - Imagem digitalizada de uma amostra de raízes finas retirada na profundidade entre 10 e $30 \mathrm{~cm}$ na linha de plantio, obtida pela varredura de um "scanner" de mesa com resolução de 400 dpi. 


\section{RESULTADOS E DISCUSSÃO}

\section{1 Área basal}

Os dados referentes ao crescimento da área basal em função das doses crescentes de biossólido são apresentados com o objetivo de relacioná-los com o desenvolvimento do sistema radicular, a temperatura do solo e a luz incidente no sub-bosque.

A Figura 7 mostra que, aos 35 meses de idade, as árvores que apresentaram maior área basal foram as do tratamento que recebeu 10 toneladas de biossólido mais complementação de potássio e fósforo (sulco de plantio) "10t+KP" e as árvores do tratamento que recebeu 40 toneladas de biossólido mais complementação de potássio " $40 \mathrm{t}+\mathrm{K}$ ". A área basal das árvores da testemunha "Tt" foi $38 \%$ inferior à área basal das árvores do tratamento "10t+KP". O tratamento "Ad" que recebeu adubação mineral completa (macro e micronutrientes) no sulco de plantio, apresentou área basal $17 \%$ inferior à área basal das árvores do tratamento " $10 t+K P "$ "

Após a fase inicial da implantação do experimento, aos 10 meses de idade, Guedes (2000) observou que os eucaliptos que mais cresceram em altura foram os dos tratamentos "Ad" e "10t+KP". Na ocasião, o autor assinalou que o adubo mineral, principalmente o fósforo, aplicado nesses tratamentos, sendo prontamente disponível, determinou uma resposta imediata das árvores. Todavia, aos 36 meses, é provável que os nutrientes adicionados via adubação mineral, tenham sido em parte absorvidos pelas raízes e em parte perdidos, devido ao processo de lixiviação que é geralmente elevado em solos arenosos. Isto pode explicar o menor valor de área basal das árvores do tratamento "Ad" em relação aos tratamentos com biossólido (Figura 7). 


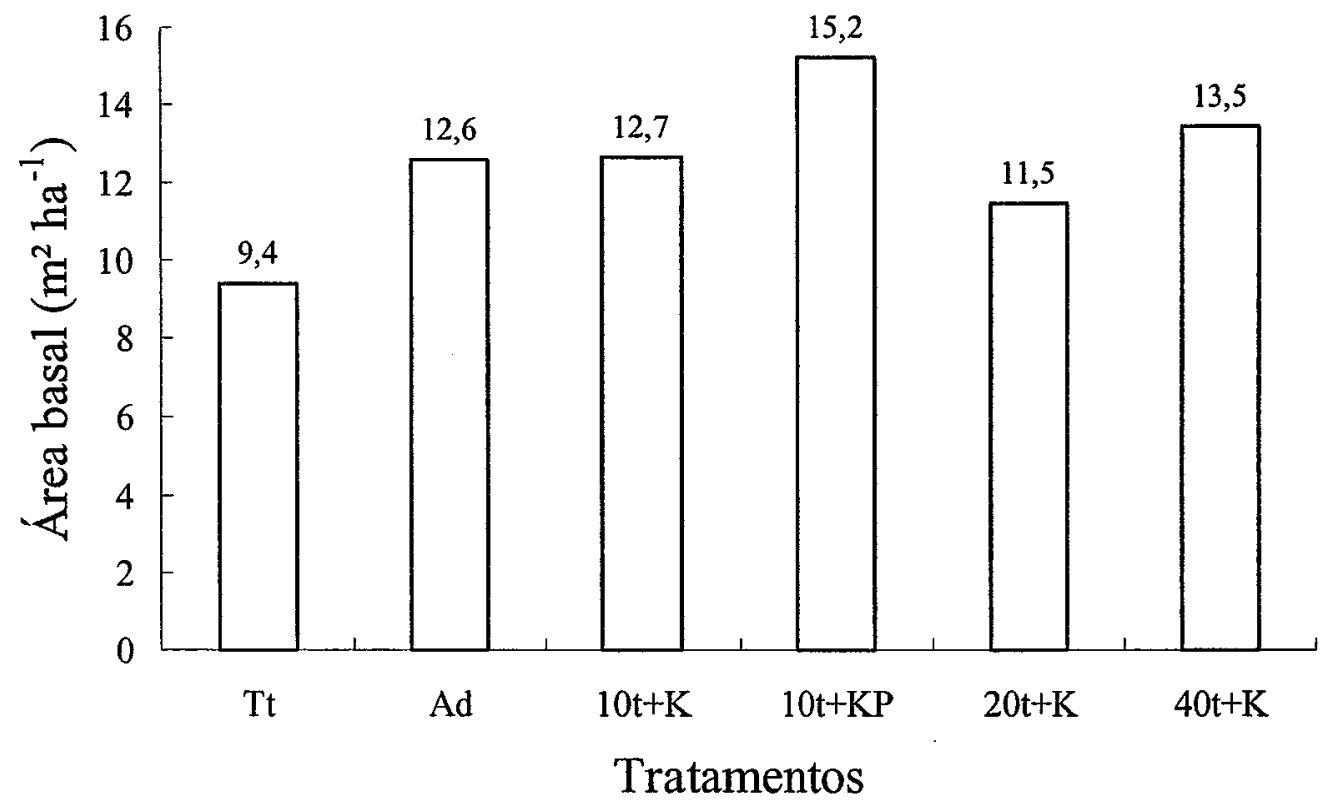

Figura 7 - Valores médios $(\mathrm{N}=36)$ da área basal das árvores de eucalipto, medidas em janeiro de 2001, aos 35 meses após o plantio.

Observa-se, portanto, que o tratamento " $40 \mathrm{t}+\mathrm{K}$ " que recebeu dose mais elevada de biossólido e complementação com potássio, já proporciona nesta fase do crescimento um incremento superior ao observado no tratamento que recebeu apenas adubação mineral "Ad". Isto evidencia que o biossólido pode atuar como uma fonte de nutrientes para os eucaliptos, mesmo 2 anos e meio após sua aplicação, devido à liberação lenta (Zabowski \& Henry, 1994). Harrison et al., (1994) observaram o aumento na concentração de nutrientes na superfície e na zona radicular mais profunda de um solo florestal, perdurando por mais de 15 anos após aplicação do biossólido, garantindo o aumento da produtividade florestal a longo prazo.

Gonçalves et al., (1990) trabalhando em diferentes sítios florestais de Eucalyptus, observaram que a produtividade do sítio é determinada pelas propriedades do solo, além 
de outras características do sítio que influenciam na qualidade e quantidade de espaço para o crescimento das raízes.

Portanto, neste experimento, podemos observar que 36 meses após a aplicação de biossólido, existe um efeito positivo deste insumo no crescimento da área basal em relação à testemunha "Tt". 


\subsection{ESTUDO DO MICROCLIMA}

\subsubsection{Luz incidente no sub-bosque}

A atenuação da radiação sob as copas das árvores depende sobretudo da densidade da copa e do arranjo das folhas em seus ramos. É sabido que a predominância da radiação difusa no sub-bosque diminui em função do grau da cobertura do dossel.

Observou-se que o valor médio da radiação fotossinteticamente ativa (RFA) registrado a céu aberto foi de $2451 \mu \mathrm{mol} \mathrm{cm} \mathrm{cm}^{-2}$. O tratamento que recebeu maior dose de biossólido " $40 \mathrm{t}+\mathrm{K}$ " apresentou o menor valor de RFA no sub-bosque $\left(64,1 \mu \mathrm{mol} \mathrm{cm} \mathrm{cm}^{-2}\right.$ $\mathrm{s}^{-1}$ ) e o tratamento " $20 \mathrm{t}+\mathrm{K}$ " uma intensidade de $68,2 \mu \mathrm{mol} \mathrm{cm} \mathrm{cm}^{-2} \mathrm{~s}^{-1}$. O tratamento "Tt" foi o que apresentou o maior valor de RFA sob o dossel, conforme mostra a Figura 8.

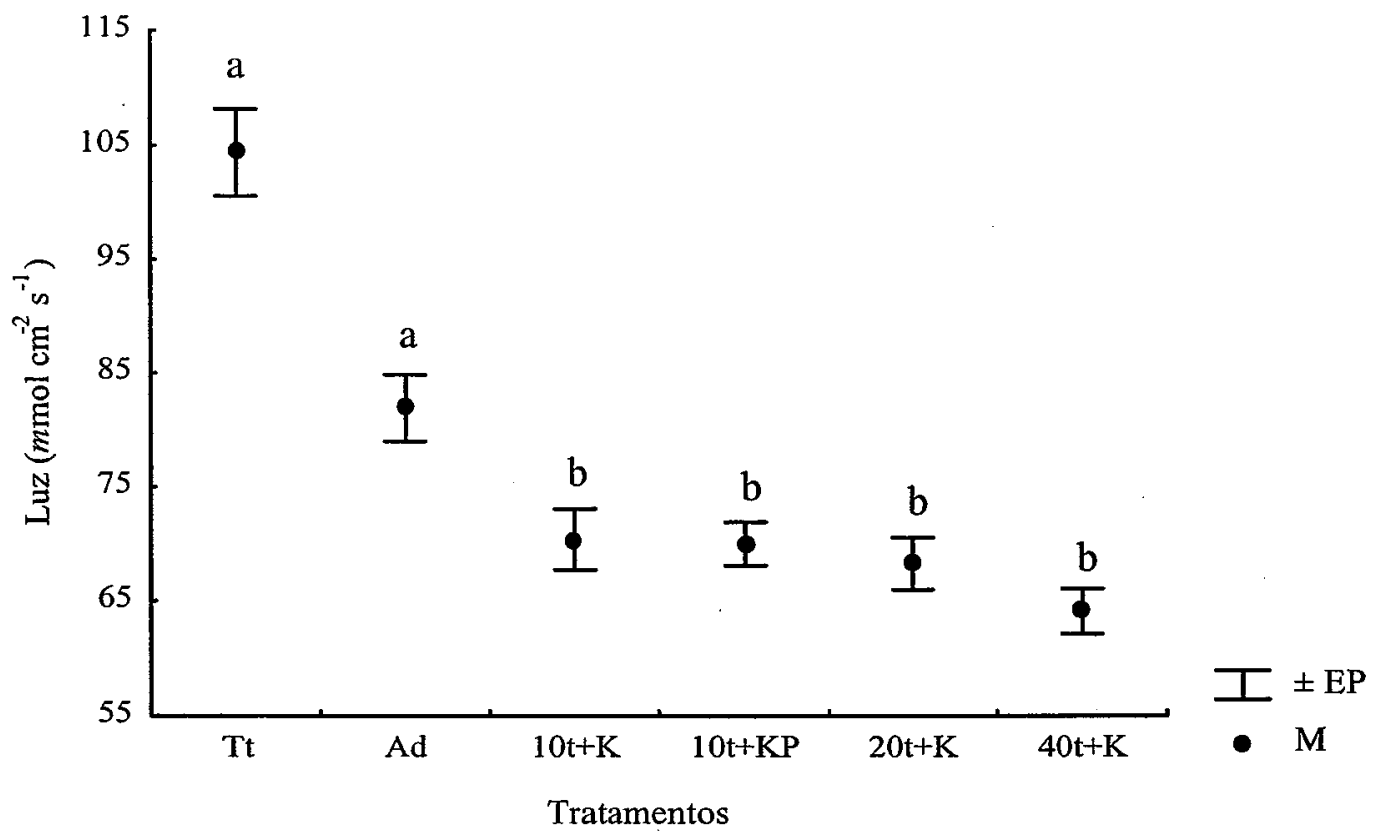

Figura 8 - Valores médios $(\mathrm{M})$ e \pm erro padrão (EP) da radiação fotossinteticamente ativa no sub-bosque do talhão experimental, em fevereiro de 2001, 36 meses após o plantio $(\mathrm{N}=20)$. Médias seguidas da mesma letra não diferem estatisticamente pelo teste Tukey a $5 \%$ de probabilidade. 
A entrada de uma menor RFA no tratamento " $40 t+K$ " indica que as árvores encontram-se com as copas mais desenvolvidas e fechadas, ocasionando portanto, maior sombreamento do sub-bosque.

Guedes (2000) em um trabalho de pesquisa desenvolvido na mesma área experimental em julho de 2000 , observou que apenas $10 \%$ da RFA registrada acima das copas atravessou o dossel e que o tratamento que recebeu maior dose de biossólido " $40 \mathrm{t}+\mathrm{K}$ " foi o que apresentou maior cobertura do dossel.

A cobertura da copa de cada árvore e o grau de densidade são fatores importantes na produtividade da floresta. Quando o suprimento nutricional é desfavorável e há escassez de água, as árvores não produzem as matérias-primas necessárias para a síntese de um sistema foliar extenso. Larcher (2000) cita que nas regiões secas e em solos pobres, surgem comunidades de plantas com copas menos desenvolvidas permitindo a incidência direta de luz no sub-bosque.

As elevadas intensidades de luz também provocam nas árvores importantes modificações morfológicas. Gonçalves \& Benedetti (2000) citam que a radiação solar está diretamente relacionada com o crescimento radicular, pois é a fonte de energia para a produção de fotoassimilados nas folhas e alocados no sistema radicular, aumentando o desenvolvimento da raiz e as razões raiz/caule. Farias et al., (1995) verificaram que o crescimento da raiz de guatambu foi incrementado significativamente pelo aumento de intensidade luminosa.

É importante assinalar também, que durante a coleta dos dados, foi observado, principalmente no tratamento " $\mathrm{Tt}$ " a incidência direta de luz do sol que penetra através de amplas brechas no dossel, formando um mosaico de luz no piso florestal, fenômeno este usual em florestas abertas como observado por Whatley \& Whatley (1982) e Spurr \& Banes (1982). Portanto, deve ser salientado que a intensidade de luz difusa não representa a incidência total de energia luminosa que penetra no interior da floresta. 


\subsubsection{Temperatura do solo nos diferentes tratamentos}

A Figura 9 mostra as diferenças entre os tratamentos em relação à temperatura do solo, tanto na superfície como a $10 \mathrm{~cm}$ de profundidade. $\mathrm{O}$ valor médio da temperatura na superfície do solo nos tratamentos foi de $26,9^{\circ} \mathrm{C}$ e a $10 \mathrm{~cm}$ de profundidade $25,4^{\circ} \mathrm{C}$. Dentre os tratamentos, o "Tt" foi que apresentou o maior valor de temperatura na superfície do solo $\left(27,9^{\circ} \mathrm{C}\right)$ e a $10 \mathrm{~cm}$ de profundidade $\left(26,1^{\circ} \mathrm{C}\right)$, devido à maior inçidência de energia radiante sobre o solo, conforme apresentado na Figura 8.

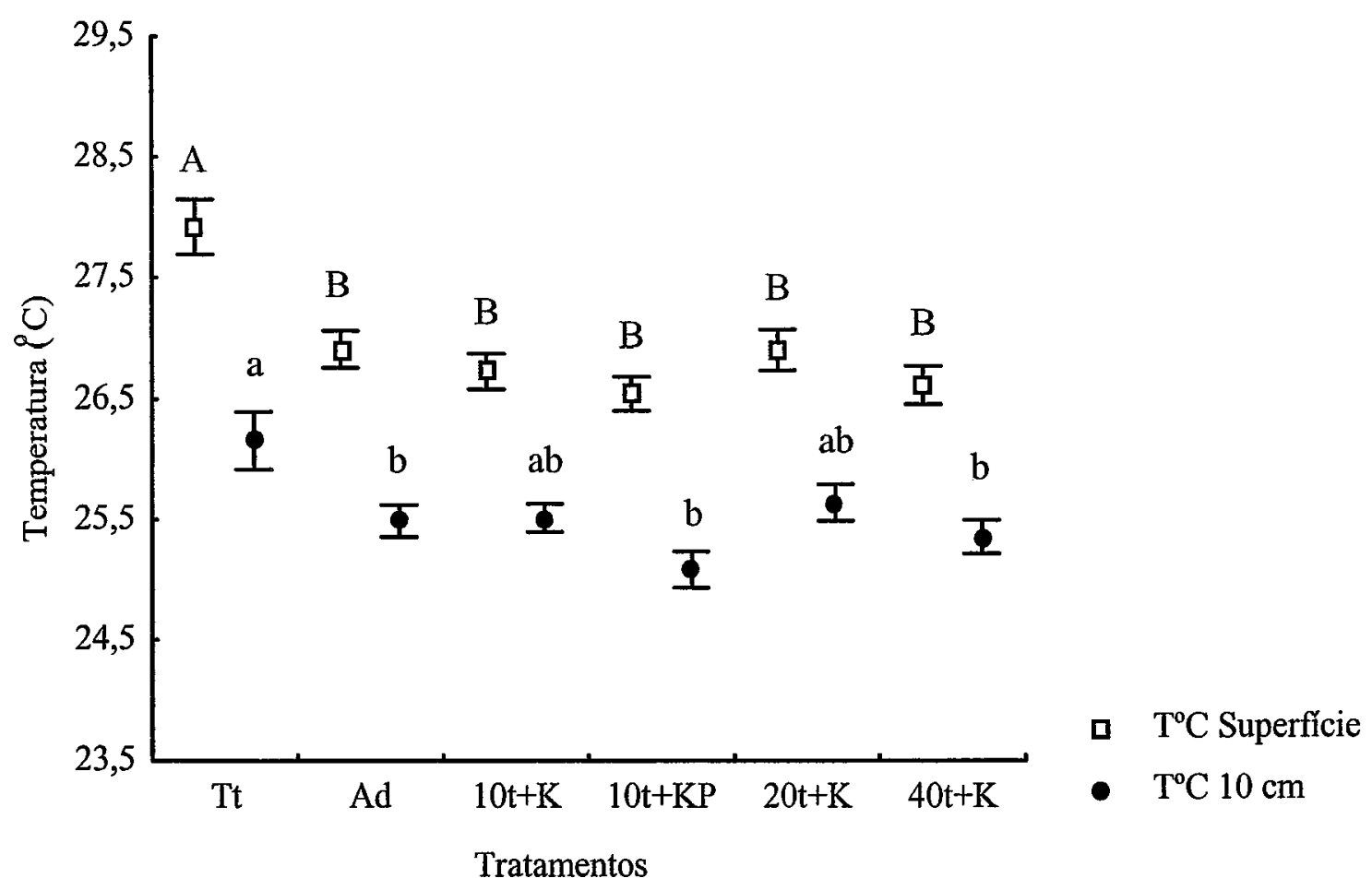

Figura 9 - Temperatura do solo (média \pm erro padrão) registrada na superficie do solo $\mathrm{e}$ a $10 \mathrm{~cm}$ de profundidade, em fevereiro de 2001. Médias seguidas da mesma letra não diferem estatisticamente pelo teste Tukey a $5 \%$ de probabilidade.

Em povoamentos florestais com vegetação densa, somente uma pequena fração da radiação solar chega ao solo. Larcher (2000) menciona que em vegetação de 
cobertura fechada, o solo é protegido da forte radiação e da perda de energia radiante. Mesmo nas camadas superiores, a flutuação da temperatura diurna é relativamente pequena, tornando-se insignificante em profundidades inferiores a $30 \mathrm{~cm}$.

Entre os tratamentos, observou-se que a $10 \mathrm{~cm}$ de profundidade, as temperaturas são sempre inferiores em relação à superfície e tendem a se igualarem, mas apenas os tratamentos "Ad", "10t+KP" e " $40 t+K$ " foram diferentes do tratamento " $\mathrm{Tt}$ ".

Quanto mais se aprofundam os pontos de amostragem de temperatura do solo, menor é a variação de temperatura encontrada. Paiva \& Poggiani (2000) avaliando o crescimento de mudas de espécies arbóreas nativas num sub-bosque de um fragmento florestal, observaram que a temperatura medida diariamente na camada superficial do solo acompanha a temperatura ambiente e que, conforme aprofundam-se os pontos de medidas no solo, as temperaturas tendem a se igualar.

Segundo Macduff et al. (1986), a temperatura do solo é um importante regulador da atividade radicular. Larcher (2000) menciona que a temperatura do solo influencia a absorção de água nas plantas. Considerando que o sistema radicular das árvores encontra-se bem desenvolvido e superficial, Sanford \& Cuevas (1996) observaram que as oscilações de temperatura ambiente podem influenciar o desenvolvimento das raízes, acelerando ou reduzindo os processos metabólicos envolvidos, junto com a água disponível no solo.

Nambiar (1983) no sul da Austrália verificou um maior incremento do comprimento em relação ao peso de raízes de Pinus radiata, quando a temperatura do solo era superior a $15^{\circ} \mathrm{C}$. Domisch et al. (2001) também observaram que o crescimento radicular e principalmente o desenvolvimento de novas raízes de Pinus sylvestris está relacionado a temperaturas mais elevadas do solo. 


\subsection{Densidade de raízes finas}

A análise de variância revelou efeito significativo, a $5 \%$ de probabilidade para densidade de raízes finas $\left(\mathrm{cm} \mathrm{cm}^{-3}\right)$, conforme mostram as Tabelas 4 e 5 .

Tabela 4. Resumo da ANOVA realizada para a densidade de raízes finas $\left(\mathrm{cm} \mathrm{cm}^{-3}\right) \mathrm{de}$ eucalipto, em função de doses crescentes de biossólido e adubação mineral, na camada entre 0 e $10 \mathrm{~cm}$ de profundidade.

\begin{tabular}{lccccc}
\hline Efeitos & gl & QM & QMR & F & P \\
\hline Tratamentos & 5 & 33,47 & 9,95 & 3,36 & $<0,01$ \\
Posição & 1 & 7,74 & 9,95 & 0,77 & 0,38 \\
Tratamento x Posição & 5 & 20,14 & 9,95 & 2,02 & 0,10 \\
Bloco & 3 & 23,01 & 9,95 & - & - \\
\hline
\end{tabular}

Tabela 5. Resumo da ANOVA realizada para a densidade de raízes finas $\left(\mathrm{cm}^{-3}\right) \mathrm{de}$ eucalipto, em função de doses crescentes de biossólido e adubação mineral, na camada entre 10 e $30 \mathrm{~cm}$ de profundidade.

\begin{tabular}{lccccc}
\hline Efeitos & gl & QM & QMR & F & P \\
\hline Tratamentos & 5 & 1,38 & 0,78 & 1,76 & 0,12 \\
Posição & 1 & 5,97 & 0,78 & 7,60 & $<0,006$ \\
Tratamento x Posição & 5 & 0,12 & 0,78 & 1,18 & 0,32 \\
Bloco & 3 & 1,91 & 0,78 & - & - \\
\hline
\end{tabular}

De acordo com a ANOVA realizada, foi evidenciada diferença na densidade de raízes finas na camada superficial do solo (nos primeiros $10 \mathrm{~cm}$ de profundidade), mas na camada inferior $(10-30 \mathrm{~cm})$ não foi observada diferença.

Na Figura 10 pode ser constatado que a densidade média de raízes finas decresceu da camada superior para a camada inferior do solo. Considerando todas as amostras coletas nas linhas e nas entrelinhas de plantio, observou-se que a densidade média de raízes finas diminuiu de $6,58 \mathrm{~cm} \mathrm{~cm}^{-3}$ nos primeiros $10 \mathrm{~cm}$ de profundidade, para $1,83 \mathrm{~cm} \mathrm{~cm}^{-3}$, na camada entre 10 e $30 \mathrm{~cm}$. 
Considerando todos os tratamentos, na camada entre 0 e $10 \mathrm{~cm}$ de profundidade, os tratamentos que apresentaram os maiores valores de densidade de raízes finas foram encontrados no tratamento " $\mathrm{Tt}$ " $\left(8,20 \mathrm{~cm} \mathrm{~cm}^{-3}\right)$ e no "Ad" $\left(7,77 \mathrm{~cm} \mathrm{~cm}^{3}\right)$.

Nos tratamentos que receberam doses crescentes de biossólido mais complementação "10t+K", "10t+KP", "20t+K" e " $40 t+K$ ", constatou-se uma diminuição na densidade de raízes finas com um valor médio de $5,87 \mathrm{~cm} \mathrm{~cm}^{-3}$, conforme mostra a Figura 10.

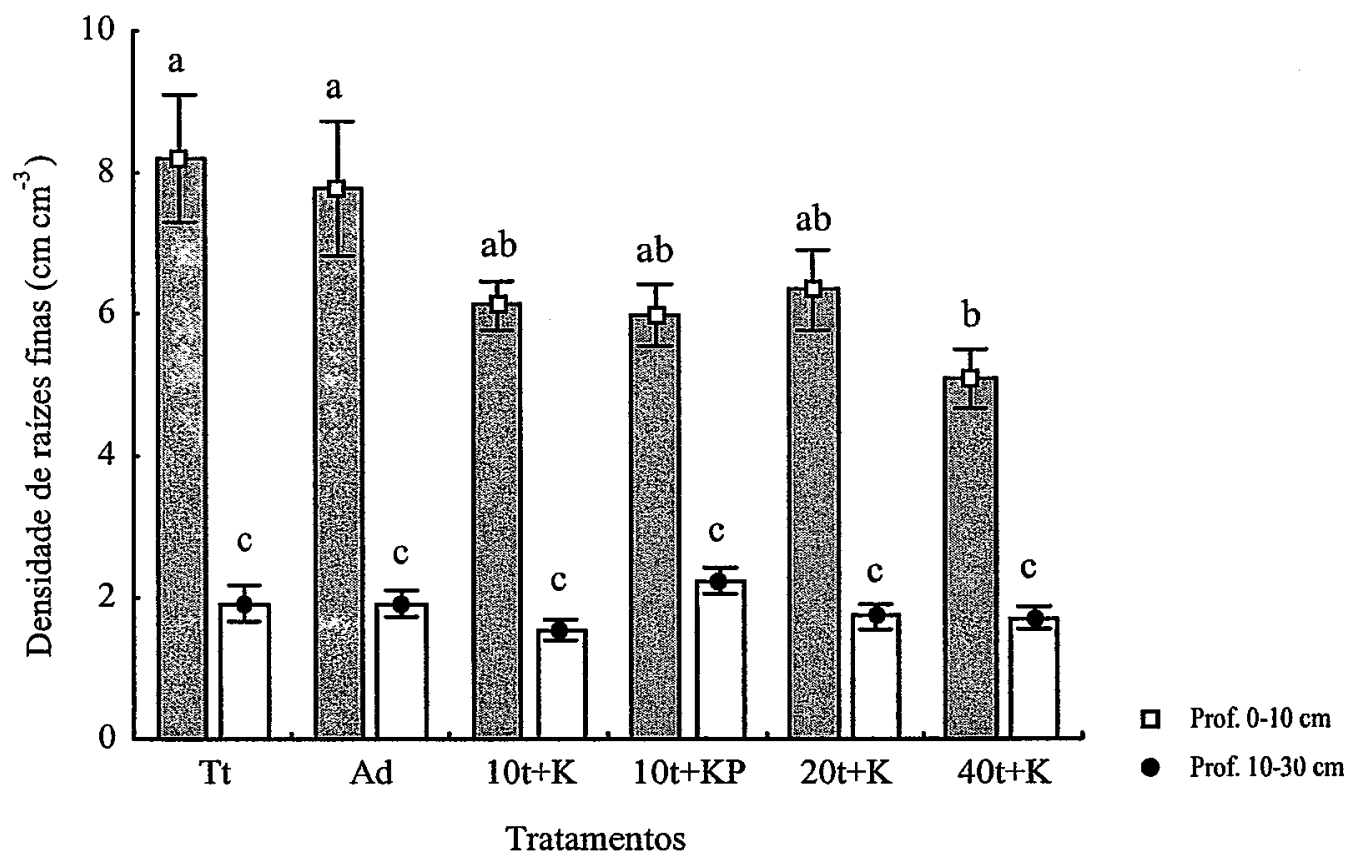

Figura 10 - Densidade de raízes finas (média \pm erro padrão), na camada entre 0 e $10 \mathrm{~cm}$ e 10 e $30 \mathrm{~cm}$ de profundidade nas parcelas experimentais de Eucalyptus grandis aos 3 anos de idade. Médias seguidas da mesma letra não diferem estatisticamente pelo teste Tukey a $5 \%$ de probabilidade.

Semelhantemente, vários autores estudando diversas espécies florestais, relataram as variações na distribuição de raízes finas no perfil do solo, sendo na camada superficial (0-10 cm de profundidade) o maior acúmulo (Kramer \& Kozlowski, 1979; 
Vogt et al., 1981; Persson, 1983; Jordan, 1985; Reis et al., 1985; Gonçalves, 1994; Leles, 1995; Barber, 1995; Sanford \& Cuevas, 1996; Mello, 1997; Anghinoni \& Meurer, 1999).

A densidade de raízes finas pode ser um fator relacionado com a característica do genótipo e neste caso específico, está estreitamente relacionada com o comportamento nutricional, potencial produtivo e capacidade de adaptação a condições de estresse ambiental.

Comparando os tratamentos que receberam doses crescentes de biossólido, verifica-se que a densidade de raízes finas caiu de forma não significativa de $6,11 \mathrm{~cm}$ $\mathrm{cm}^{-3}$ no " $10 \mathrm{t}+\mathrm{K}$ " para $5,07 \mathrm{~cm} \mathrm{~cm}^{-3}$ no " $40 \mathrm{t}+\mathrm{K}$ ". Todavia, fazendo-se uma comparação entre os tratamentos "Tt", "Ad" e "40t+K", na camada superficial do solo, constata-se que a densidade de raízes no tratamento " $40 \mathrm{t}+\mathrm{K}$ ", foi $36 \%$ inferior à dos tratamentos "Tt" e "Ad". Estes resultados estão de acordo com as observações de Reis et al., (1985) e Gonçalves (1994), ou seja, quanto maior é a produtividade do sítio, relacionada com a fertilidade do solo, menor é a densidade de raízes.

Fazendo uma analogia com os dados de nutrição e de ciclagem dos nutrientes de trabalhos desenvolvidos por outros pesquisadores, que integram este projeto na mesma área experimental, podemos observar, por exemplo, que: Vaz (2000) observou que a elevação das doses de biossólido de 0 a $40 \mathrm{tha}^{-1}$, resultou em ganhos na produtividade de madeira. Este autor atribuiu o fato à maior disponibilidade de nutrientes liberados pelo biossólido. Guedes (2000) observou que o tratamento " $40 t+K$ ” aumentou em $40 \%$ a produção e também a decomposição de folhedo, disponibilizando mais nutrientes para as raízes comparado com o tratamento "Tt". Portanto, a partir desses dados, pode-se inferir que, com a melhoria das condições químicas e físicas do solo, promovidas pela adição do biossólido, pode estar reduzindo a necessidade da alocação dos fotoassimilados das copas das árvores para a produção de raízes finas. Isto justificaria os menores valores de densidade de raízes finas observados nos tratamentos com doses crescentes de biossólido.

A menor densidade de raízes finas nos tratamentos com biossólido, indicam que as árvores, por meio de seus sistemas radiculares, possuem grande capacidade de 
interação com as características do solo. Certamente esse é um mecanismo que as raízes utilizam para ampliar ou reduzir suas capacidades de absorção de água e nutrientes, seguindo as condições físicas e químicas do solo. Assim, sob condições restritivas do solo, a densidade de raízes finas seria ampliada, permitindo que um maior volume de solo seja explorado, aumentando a capacidade de absorção de água e nutrientes (Kramer \& Kozlowski, 1979; Reis et al., 1985; Gonçalves, 1994)

Quando a disponibilidade de água e nutrientes é baixa, as árvores alocam maior quantidade de fotoassimilados às raízes, reduzindo a relação parte aérea/sistema radicular. Este maior dispêndio de energia para a produção de raízes reduz a produção de biomassa nas partes aéreas das árvores. Estas observações estão de acordo com a teoria fonte-dreno, ou seja, as árvores ampliam seu sistema radicular para aumentar a capacidade de absorção de água e nutrientes nos solos menos férteis conforme assinalado por Gonçalves \& Benedetti (2000).

É importante ressaltar também que em solo de baixa fertilidade (considerando o tratamento "Tt", que possui maior densidade de raízes finas), uma das principais fontes de nutrientes para as árvores vem dos processos de ciclagem biogeoquímica de nutrientes, disponibilizados por intermédio da mineralização da matéria orgânica presente, predominantemente, nas raízes finas em decomposição, de folhedo e de resíduos vegetais depositados sobre o solo. Deste modo, podemos considerar que no tratamento menos produtivo "Tt", as árvores ampliam seu sistema radicular na superfície do solo para aumentar as possibilidades de absorção dos nutrientes presentes neste compartimento.

Nas Figuras 11 e 12, observa-se o comportamento das raízes finas em relação aos tratamentos. Considerando somente as amostras das linhas de plantio, na camada superficial $(0-10 \mathrm{~cm})$, é possível observar que, apesar de não terem sido verificadas diferenças significativas entre os tratamentos "Tt", "Ad", "10t+K" e " $10 t+K P$ ", o tratamento "Ad" apresenta a maior densidade de raízes finas. O tratamento "Ad", tendo recebido inicialmente fertilização mineral completa na linha de plantio, pode ter perdido, após alguns meses, seu nível de fertilidade, devido ao rápido esgotamento dos nutrientes. Conseqüentemente, o sistema radicular estaria se expandindo para atender às 
necessidades hídricas e nutricionais da parte aérea dos eucaliptos que continua em franco crescimento.

Nas linhas de plantio ocorre uma tendência para a diminuição da densidade de raízes finas com as maiores doses de biossólido e principalmente considerando o tratamento " $40 \mathrm{t}+\mathrm{K}$ ".

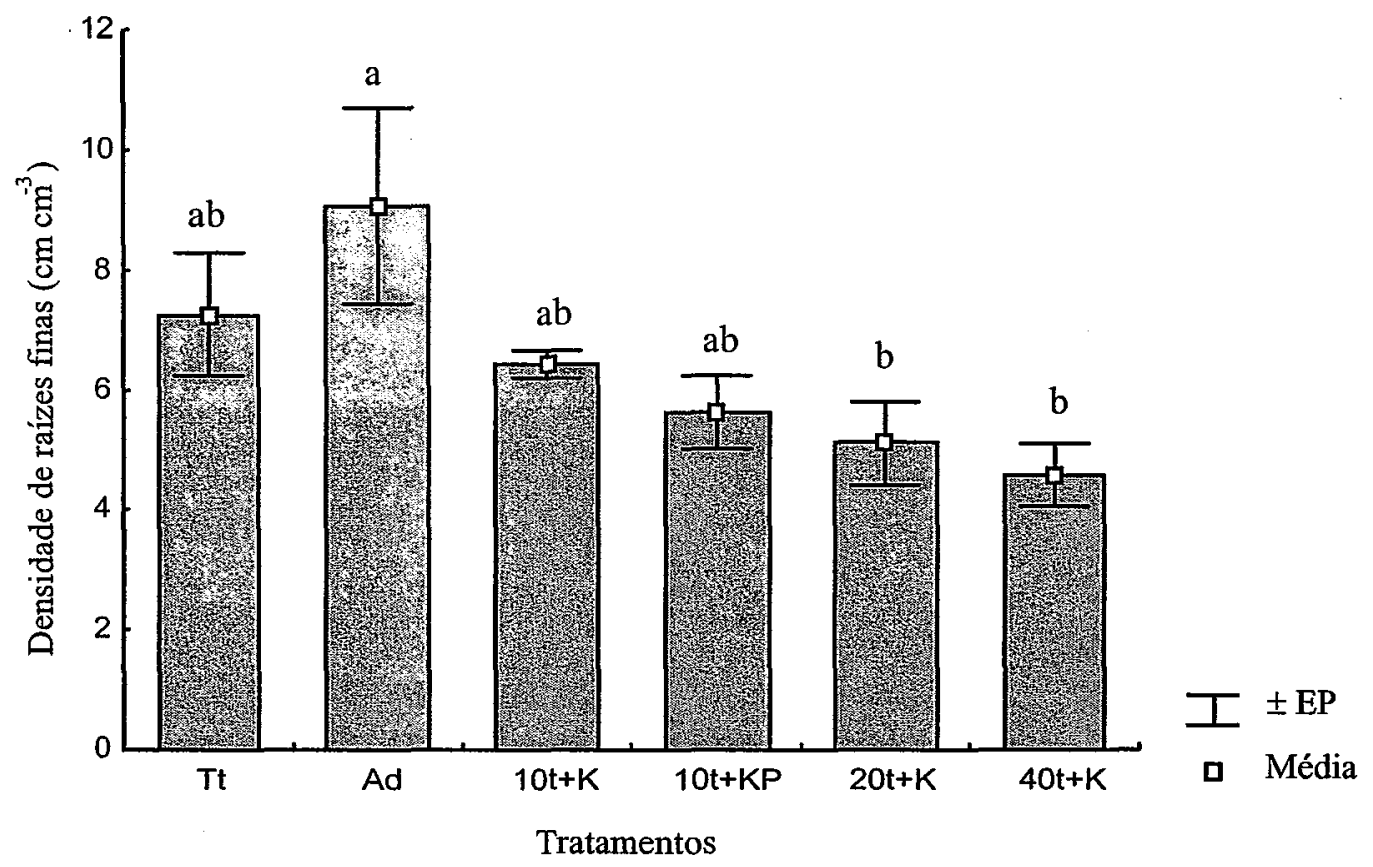

Figura 11 - Densidade de raízes finas (média \pm erro padrão) na camada entre 0 e $10 \mathrm{~cm}$ de profundidade, nas linhas de plantio. Médias seguidas da mesma letra não diferem estatisticamente pelo teste Tukey a $5 \%$ de probabilidade.

Quanto as entrelinhas de plantio, local onde foi aplicado o biossólido, o tratamento "Tt" foi o que apresentou a maior densidade de raízes finas $\left(9,13 \mathrm{~cm} \mathrm{~cm}^{-3}\right)$, e o tratamento " $40 \mathrm{t}+\mathrm{K}$ " a menor densidade $\left(5,57 \mathrm{~cm} \mathrm{~cm}^{-3}\right)$, conforme mostra a Figura 12. Todavia não foi detectada diferença estatística entre os tratamentos, devido à grande variabilidade das amostras coletadas em cada parcela experimental e que pode ser 
atribuída, entre outras coisas, à desuniformidade da distribuição do biossólido nas entrelinhas dos eucaliptos.

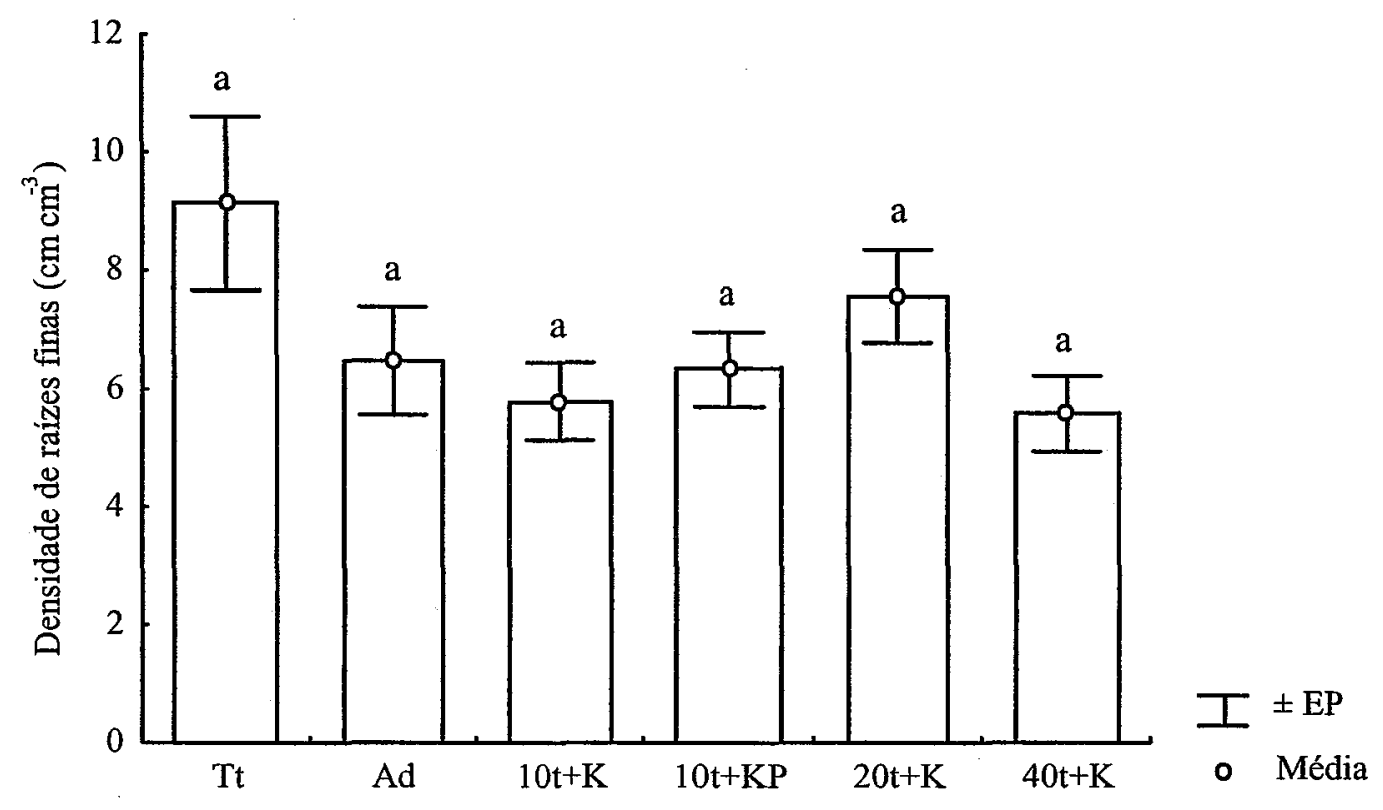

Tratamentos

Figura 12 - Densidade de raízes finas (média \pm erro padrão) na camada entre 0 e $10 \mathrm{~cm}$ de profundidade, nas entrelinhas de plantio. Médias seguidas da mesma letra não diferem estatisticamente pelo teste Tukey a $5 \%$ de probabilidade.

Conforme já mencionado, o tratamento "Tt" apresenta a menor área basal (Figura 7) e copas menos densas, conforme observado através dos altos valores de RFA sob o dossel entre os tratamentos (Figuras 8). Portanto, o seu solo recebe uma maior quantidade de energia solar, que promove a elevação da temperatura (Figura 9), propiciando um aumento da densidade radicular, conforme observado por Nambiar (1983) e Domisch et al., (2001).

Macduff et al, (1986) avaliando os efeitos da temperatura sobre os parâmetros radiculares, observou que a temperatura do solo influencia no aumento, na produção e 
no crescimento de raízes finas, em conjunto com outros fatores que incluem a umidade do solo, a disponibilidade de nutrientes, $\mathrm{pH}$ e microrganismos.

De modo geral, considerando todos os tratamentos, observa-se uma tendência para a redução de densidade de raízes finas nas parcelas onde foram adicionadas as doses mais elevadas de biossólido. Todavia, esta diferença parece não ser muito consistente, quando se comparam os resultados das amostras coletadas nas linhas com as amostras coletadas nas entrelinhas de plantio. Isto pode ser atribuído também à redistribuição dos nutrientes sobre o solo das parcelas experimentais causado pela produção contínua de serapilheira que, devido à altura das árvores (aproximadamente 15 m), deposita-se de forma bastante homogênea, tanto nas entrelinhas como nas linhas de plantio. Uma vez depositada, a serapilheira entra em processo de decomposição, disponibilizando os nutrientes para as raízes finas que se propagam ativamente na camada superficial do povoamento florestal.

Guedes (2000) estudando o mesmo povoamento florestal, registrou de setembro de 1998 a maio de 2000 uma deposição acumulada de $1,9 \mathrm{tha}^{-1}$ de serapilheira no tratamento " $\mathrm{Tt}$ " e de $4,6 \mathrm{t} \mathrm{ha} \mathrm{C}^{-1}$ no tratamento que recebeu a dose mais elevada de biossólido "40t+K".

É compreensivel, portanto, que dois anos após o fechamento das copas, a diferença entre a densidade de raízes finas na superfície do solo $(0-10 \mathrm{~cm})$, observada nas linhas e nas entrelinhas de plantio, seja pouco evidente.

Para os tratamentos que receberam doses crescentes de biossólido, podemos observar que, aparentemente as raízes finas se concentraram na superfície do solo próximo ao biossólido. Esse comportamento pode ser explicado, considerando que a presença do biossólido já garante as condições necessárias de fertilidade e umidade próximo à superfície. É na superfície do solo, principalmente no caso dos solos extremamente pobres e arenosos, que se concentra a maior fração dos nutrientes e é onde a ciclagem biogeoquímica acontece com maior intensidade.

A seguir é apresentada a equação de regressão obtida para a distribuição da densidade de raízes finas apenas nos tratamentos que receberam doses crescentes de biossólidos (Figura 13). O ajuste de modelo linear de regressão para os dados de 
densidade de raizes finas das entrelinhas de plantio não foi significativo $\left(\mathrm{R}^{2}=0,35\right.$; $\mathrm{p}=0,12)$.

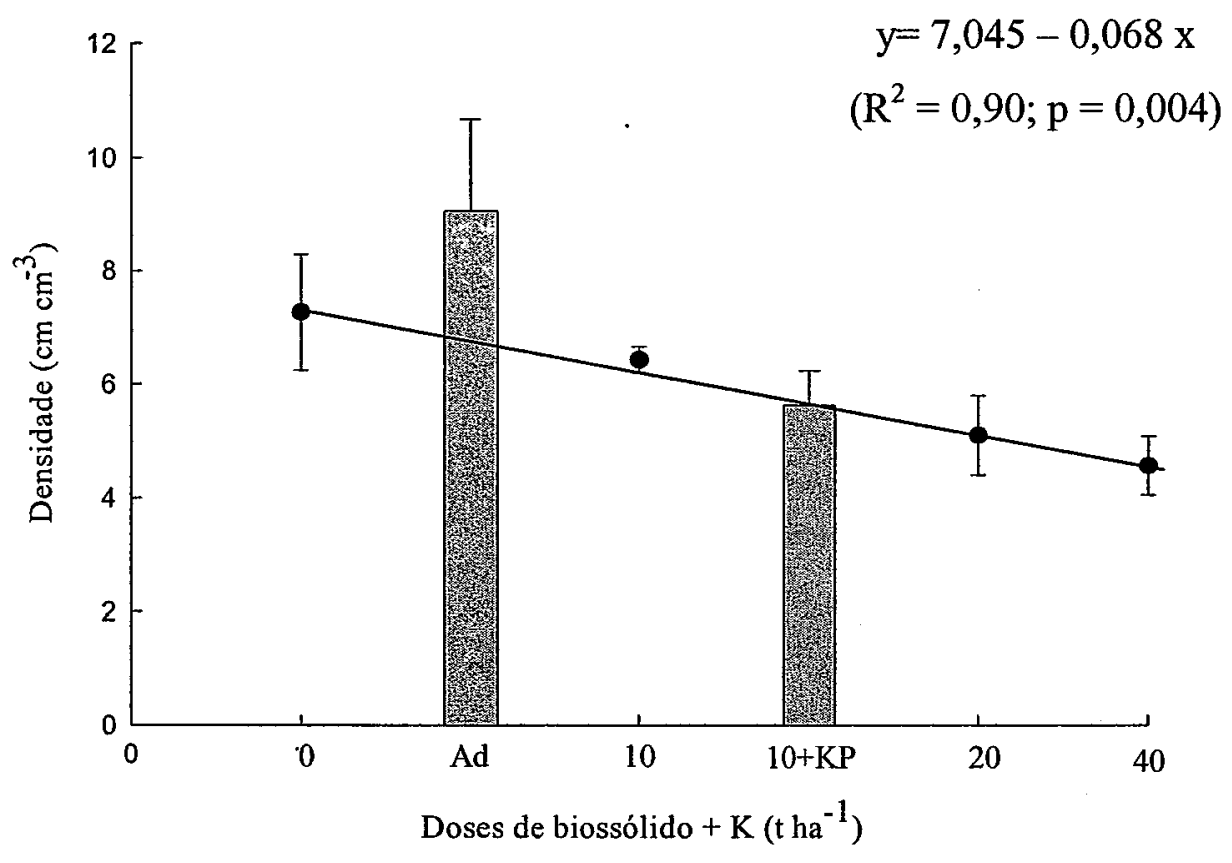

Figura 13 - Densidade de raízes finas coletadas nas linhas de plantio na camada entre 0 e $10 \mathrm{~cm}$ de profundidade, em função das doses crescentes de biossólido + $\mathrm{K}$. 


\subsection{Diâmetro de raízes finas}

A análise de variância revelou efeito significativo a $5 \%$ de probabilidade para o diâmetro médio de raízes finas na camada entre 0 e $10 \mathrm{~cm}$, sob as faixas de aplicação de doses crescentes de biossólido (entrelinhas de plantio), e sob as faixas que não receberam biossólido (linhas de plantio), conforme mostra a Tabela 6 .

Tabela 6. Resumo da ANOVA realizada para o diâmetro médio de raízes finas ( $\mathrm{mm}$ ) de eucalipto, em função de doses crescentes de biossólido e adubação mineral na camada entre 0 e $10 \mathrm{~cm}$ de profundidade.

\begin{tabular}{lccccc}
\hline Efeitos & gl & QM & QMR & F & P \\
\hline Tratamentos & 5 & 0,030 & 0,005 & 5,26 & $<0,01$ \\
Posição & 1 & 0,291 & 0,005 & 51,16 & $<0,01$ \\
Tratamento x Posição & 5 & 0,029 & 0,005 & 4,99 & $<0,001$ \\
Bloco & 3 & 0,007 & 0,005 & - & - \\
\hline
\end{tabular}

Quanto à camada entre 10 e $30 \mathrm{~cm}$ de profundidade, nas entrelinhas de plantio e nas linhas de plantio do eucalipto, a análise de variância revela que não houve diferença entre os tratamentos, conforme mostra a Tabela 7.

Tabela 7. Resumo da ANOVA realizada para o diâmetro médio de raízes finas (mm) de eucalipto, em função de doses crescentes de biossólido e adubação mineral na camada entre 10 e $30 \mathrm{~cm}$ de profundidade.

\begin{tabular}{lccccc}
\hline Efeitos & gl & QM & QMR & F & P \\
\hline Tratamentos & 5 & 0,003 & 0,005 & 0,538 & 0,747 \\
Posição & 1 & 0,007 & 0,005 & 1,267 & 0,262 \\
Tratamento x Posição & 5 & 0,002 & 0,005 & 0,524 & 0,757 \\
Bloco & 3 & 0,008 & 0,005 & - & - \\
\hline
\end{tabular}


Analisando as profundidades amostradas $(0-10$ e 10-30 cm), considerando todas as amostras coletadas nas linhas e nas entrelinhas de plantio, observa-se que na camada superficial $(0-10 \mathrm{~cm})$, apenas o diâmetro médio do tratamento “Tt" poderia ser considerado maior do que os outros tratamentos. Todavia, estatisticamente, não se observa diferença nas duas profundidades (Figura 14).

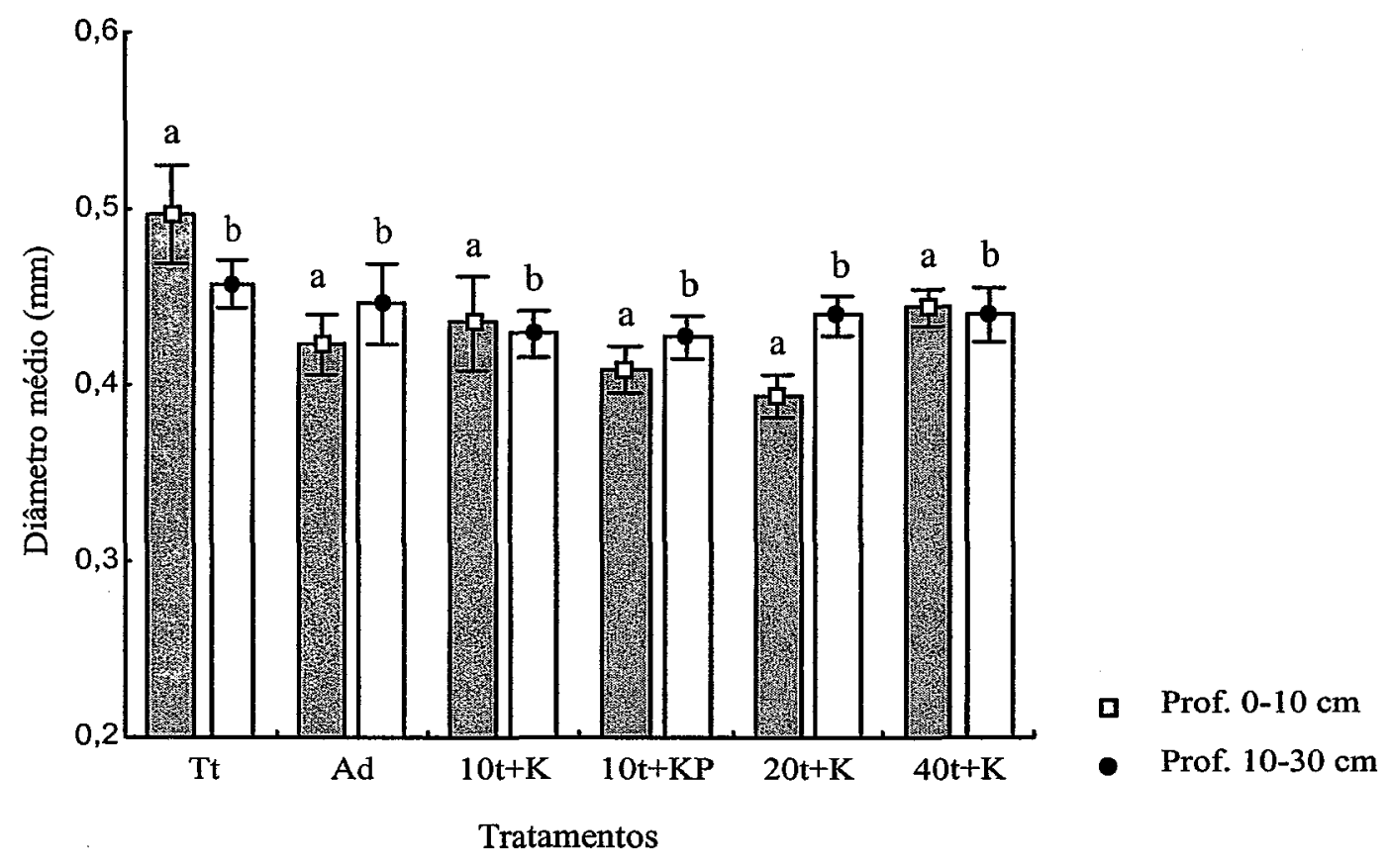

Figura 14 - Diâmetro de raízes finas (média \pm erro padrão), na camada entre 0 e $10 \mathrm{~cm} \mathrm{e}$ 10 e $30 \mathrm{~cm}$ de profundidade nas parcelas experimentais de Eucalyptus grandis aos 3 anos de idade. Médias seguidas da mesma letra não diferem estatisticamente pelo teste Tukey a 5\% de probabilidade.

Segundo Farey \& Hughes (1994), os nutrientes do solo seriam absorvidos mais eficientemente pela minimização do diâmetro radicular e maximização do comprimento. Eissenstat (1992) observou que as raízes com maior comprimento radicular e com menor diâmetro foram capazes de proliferar mais rapidamente, principalmente aquelas da camada superficial do solo. Este mesmo autor observou um diâmetro menor e um 
comprimento maior na camada superficial do solo, pois esta camada é mais rica em nutrientes do que camadas mais profundas.

Analisando-se separadamente as posições de plantio (linhas e entrelinhas), constatou-se que nas linhas de plantio o diâmetro médio dos tratamentos foi de $0,47 \mathrm{~mm}$. Entretanto, o tratamento "Tt" apresentou um diâmetro médio significativamente maior de $0,59 \mathrm{~mm}$ em relação aos demais tratamentos, exceto para o "10t+K" (Figura 15).

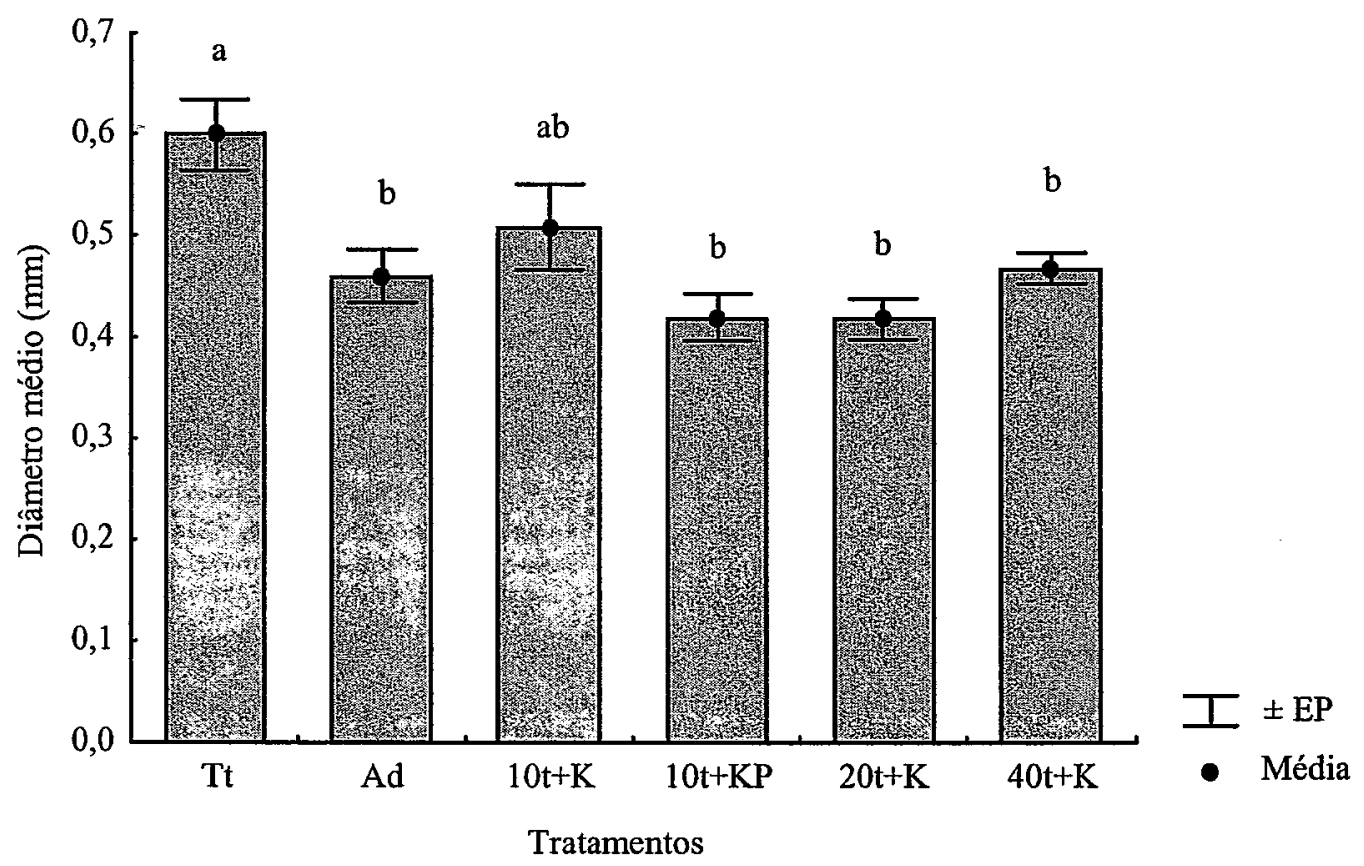

Figura 15 - Diâmetro de raízes finas (média \pm erro padrão), na camada entre 0 e $10 \mathrm{~cm}$, nas linhas de plantio. Médias seguidas da mesma letra não diferem estatisticamente pelo teste Tukey a $5 \%$ de probabilidade.

Nas entrelinhas de plantio, o solo mais adensado, parece inibir o diâmetro das raízes que apresentou em média $0,38 \mathrm{~mm}$. Observa-se na Figura 16 que apenas o tratamento que recebeu a dose mais elevada de biossólido " $40 \mathrm{t}+\mathrm{K}$ " evidenciou ligeiro e não significativo aumento no diâmetro médio das raízes finas. Em geral, doses crescentes de biossólido parecem não afetar de maneira acentuada o diâmetro das raízes. 


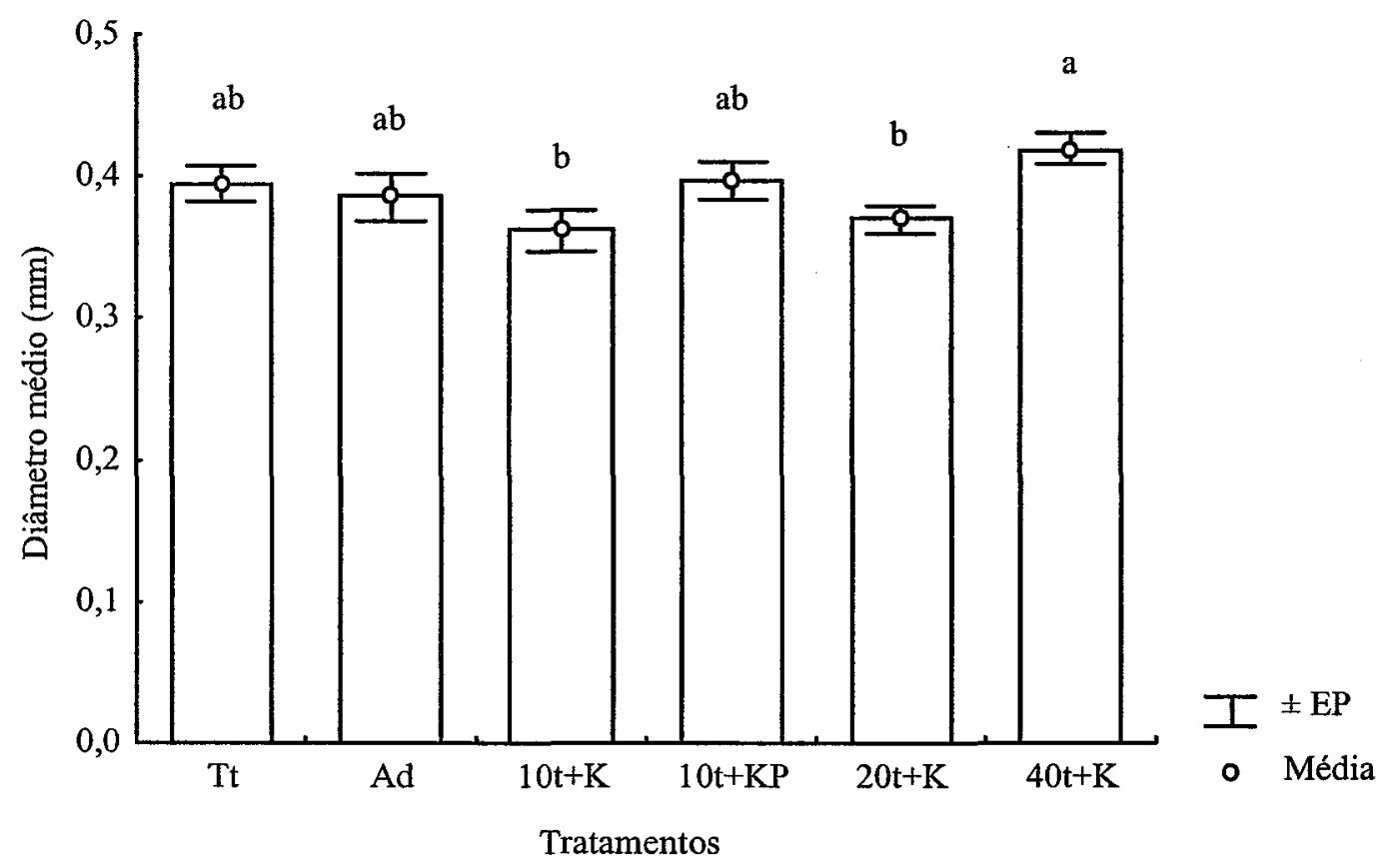

Figura 16 - Diâmetro de raízes finas (média \pm erro padrão) na camada entre 0 e $10 \mathrm{~cm}$, nas entrelinhas de plantio. Médias seguidas da mesma letra não diferem estatisticamente pelo teste Tukey a $5 \%$ de probabilidade.

A razão das raízes finas apresentarem um diâmetro médio maior nas linhas de plantio $(0,47 \mathrm{~mm})$, em relação às entrelinhas $(0,38 \mathrm{~mm})$, pode ser atribuído ao solo menos compactado, visto que no momento da implantação florestal, foi utilizado um escarificador mono-haste que realizou o preparo e a fertilização de base, revolvendo a camada de solo entre 0 e $30 \mathrm{~cm}$ e tornando-a mais permeável.

Chiaranda (1989) avaliando em condições controladas o efeito da compactação do solo em mudas de Eucalyptus toleriana e de Eucalyptus grandis, observou que os tratamentos em solo compactado apresentaram valores menores de diâmetro que os tratamentos em solo não compactado, concluindo que o solo mais permeável favorece o desenvolvimento das raízes em comprimento e diâmetro. 
Nas entrelinhas de plantio, faixa esta onde foram aplicadas as doses crescentes de biossólido, o solo encontra-se mais adensado, pois no momento da reforma do talhão, a presença de tocos de grande porte impossibilitou o realinhamento (preparo do solo em nível ou mínimo desnível), sendo a operação de plantio realizada nas entrelinhas do povoamento anterior.

Taylor et al., (1983) e Kramer \& Boyer (1995) argumentam que as propriedades físicas do solo afetam o crescimento radicular diretamente pela restrição da penetração das raízes e indiretamente pelo efeito na aeração e no conteúdo de água no solo. A compactação modifica o espaço poroso do solo, alterando seriamente as condições de armazenamento de água, além do suprimento de oxigênio e nutrientes, aumentando ainda a resistência à penetração das raízes. Essas modificações nos processo físicos do solo, afetam o crescimento e o desenvolvimento das raízes.

O solo pode ser quimicamente adequado para o crescimento e desenvolvimento de uma árvore, mas se há compactação, as plantas não se beneficiam adequadamente dos nutrientes, uma vez que o desenvolvimento de novas raízes fica prejudicado. Além disso, com a compactação, diminuem os espaços livres do solo, e, conseqüentemente, a quantidade de oxigênio disponível na rizosfera (Kramer \& Kozlowski, 1979).

A diminuição da presença de oxigênio nas raízes pode ser um fator limitante para o desempenho dos processos metabólicos da planta. Taylor et al., (1983) mencionam que o crescimento das raízes requer um suprimento contínuo de oxigênio para a respiração. Em solos compactados cujo suprimento de oxigênio é baixo, a elongação das raízes pode ser lenta ou até mesmo ocasionar a morte. A baixa concentração de oxigênio no solo pode levar a alta concentração de etileno que também é um fator limitante, pois inibe a elongação e o diâmetro das raízes finas.

Em linhas gerais, pode-se dizer que o estudo sobre o crescimento radicular deve ser feito através da avaliação das características das raízes, como: massa, comprimento, diâmetro e superfície, sempre levando em conta os fatores do ambiente que influenciam a distribuição das raízes, como densidade e porosidade do solo, água e ar disponíveis no solo, presença de serapilheira, nutrientes, $\mathrm{pH}$ e temperatura do solo, dentre outros. Entretanto, poucos estudos ainda foram realizados com espécies arbóreas no Brasil. 
Neste experimento, observou-se uma elevada variabilidade inerente aos dados de densidade e diâmetro de raízes finas. É provável também que a dificuldade metodológica de se distribuir o biossólido sobre o solo durante a implantação do experimento, tenha influenciado para acentuar a heterogeneidade das amostras coletadas.

As equações de regressões obtidas para a distribuição do diâmetro médio de raízes finas nos tratamentos que receberam doses crescentes de biossólidos, são aqui apresentadas quanto à posição de coleta das amostras nas linhas e entrelinhas de plantio (Figura 17). 
(A)

$$
\begin{gathered}
y=0,605-0,013 x+0,0002 x^{2} \\
\left(R^{2}=0,97 ; p=0,004\right)
\end{gathered}
$$

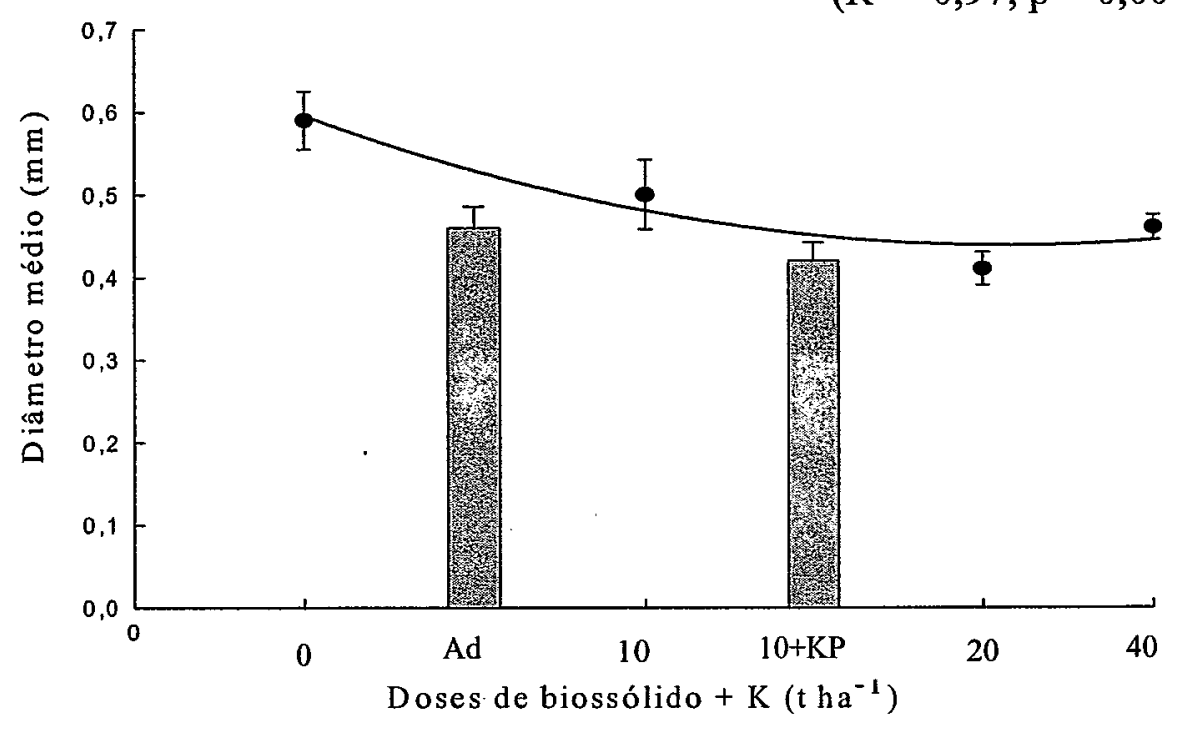

(B)

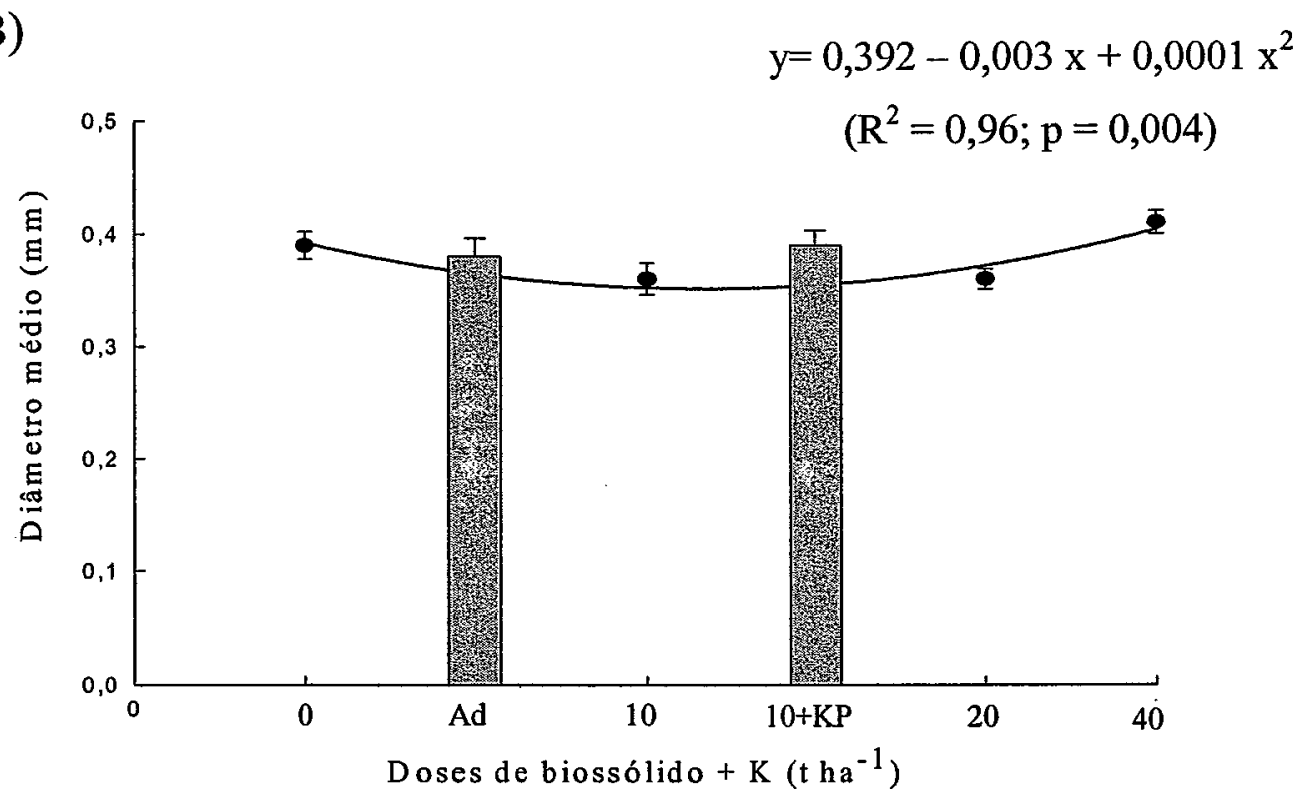

Figura 17 - Diâmetro médio de raízes finas coletadas nas linhas (A) e nas entrelinhas (B) de plantio na camada entre 0 e $10 \mathrm{~cm}$, em função das doses crescentes de biossólido $+\mathrm{K}$. 


\subsection{Superfície específica de raízes finas}

De acordo com Barber (1995), a superfície radicular é considerada como uma das melhores características para avaliar a capacidade de absorção de nutrientes e água pelas plantas. Na Figura 18 pode ser observado que, considerando todas as amostras coletadas nas linhas e entrelinhas, a maior superficie específica de raízes finas foi encontrada na camada superficial $\left(0\right.$ e $10 \mathrm{~cm}$ ), com média entre os tratamentos de $0,87 \mathrm{~cm}^{2} \mathrm{~cm}^{-3}$. Na camada inferior do solo $(10$ e $30 \mathrm{~cm})$, a média foi de $0,24 \mathrm{~cm}^{2} \mathrm{~cm}^{-3}$. Esta distribuição acompanha o padrão de distribuição da densidade de raízes (Figura 10). Este comportamento foi também observado por Berish \& Ewel (1988) em avaliação de raízes de espécies da floresta tropical, na Costa Rica e por Schwengber et al., (1994) com raízes de seringueira.

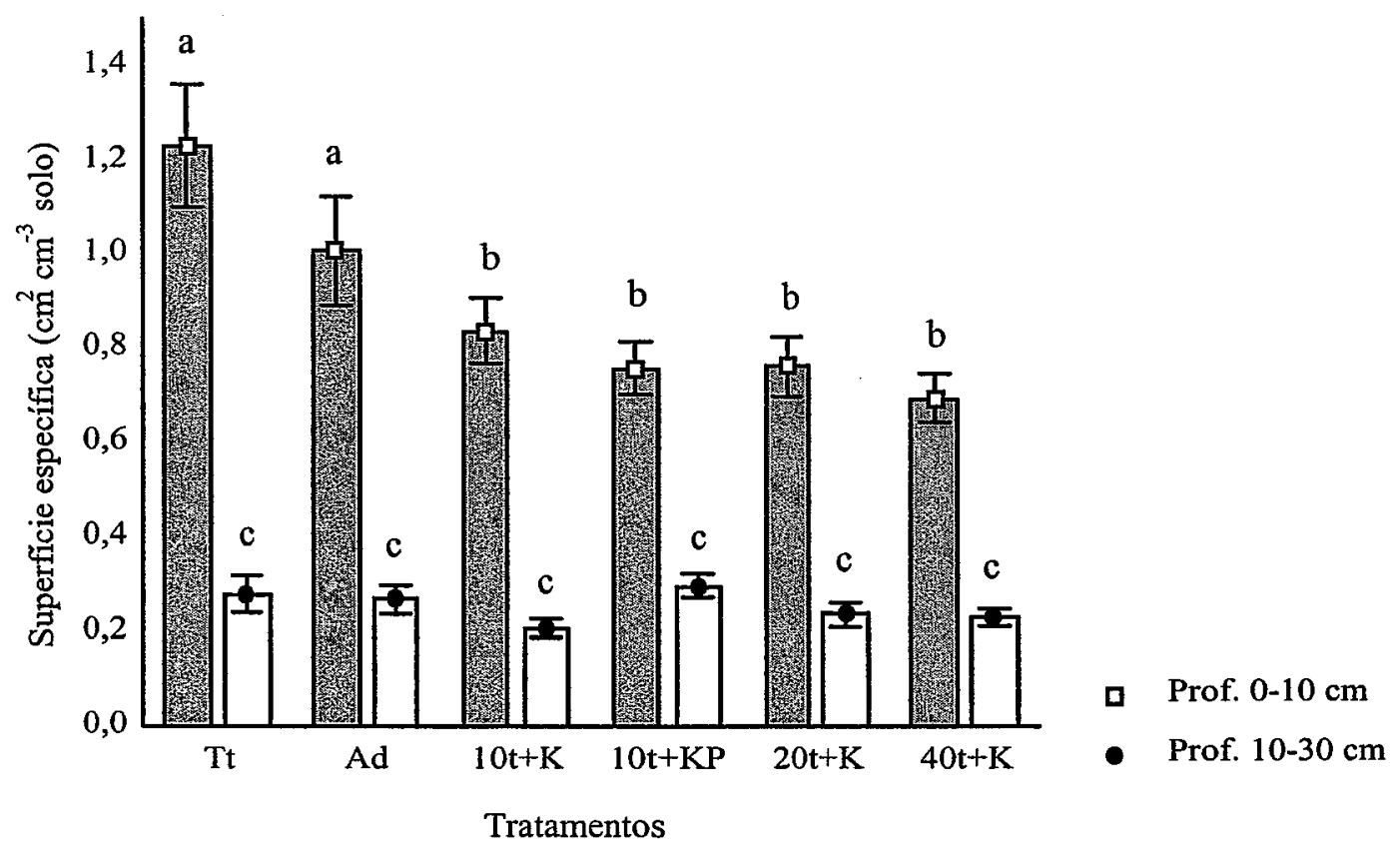

Figura 18 - Superfície específica de raízes finas (média \pm erro padrão) na camada entre 0 e 10 e 10 e $30 \mathrm{~cm}$ nas parcelas experimentais. Médias seguidas da mesma letra não diferem estatisticamente pelo teste Tukey a 5\% de probabilidade. 
Quanto à posição de coleta, a superfície específica média das raízes finas dos tratamentos nas linhas de plantio foi de $0,94 \mathrm{~cm}^{2} \mathrm{~cm}^{-3}$ ao passo que nas entrelinhas de plantio foi de $0,81 \mathrm{~cm}^{2} \mathrm{~cm}^{-3}$.

Na camada entre 0 e $10 \mathrm{~cm}$, nas linhas de plantio, a superfície específica foi significativamente maior no tratamento " $\mathrm{Tt}$ " $\left(1,36 \mathrm{~cm}^{2} \mathrm{~cm}^{-3}\right)$ e no tratamento "Ad" $(1,23$ $\mathrm{cm}^{2} \mathrm{~cm}^{-3}$ ) (Figura 19). Este comportamento parece ser coerente do ponto de vista fisiológico, pois as plantas de solos pobres nutricionalmente (considerando menos férteis os tratamentos "Tt" e "Ad"), desenvolvem mais raízes para explorar uma maior área na busca de nutrientes.

Observa-se também uma queda na superfície específica de raízes finas em resposta às doses crescentes de biossólido, semelhante ao verificado para a densidade de raízes finas (Figura 11).

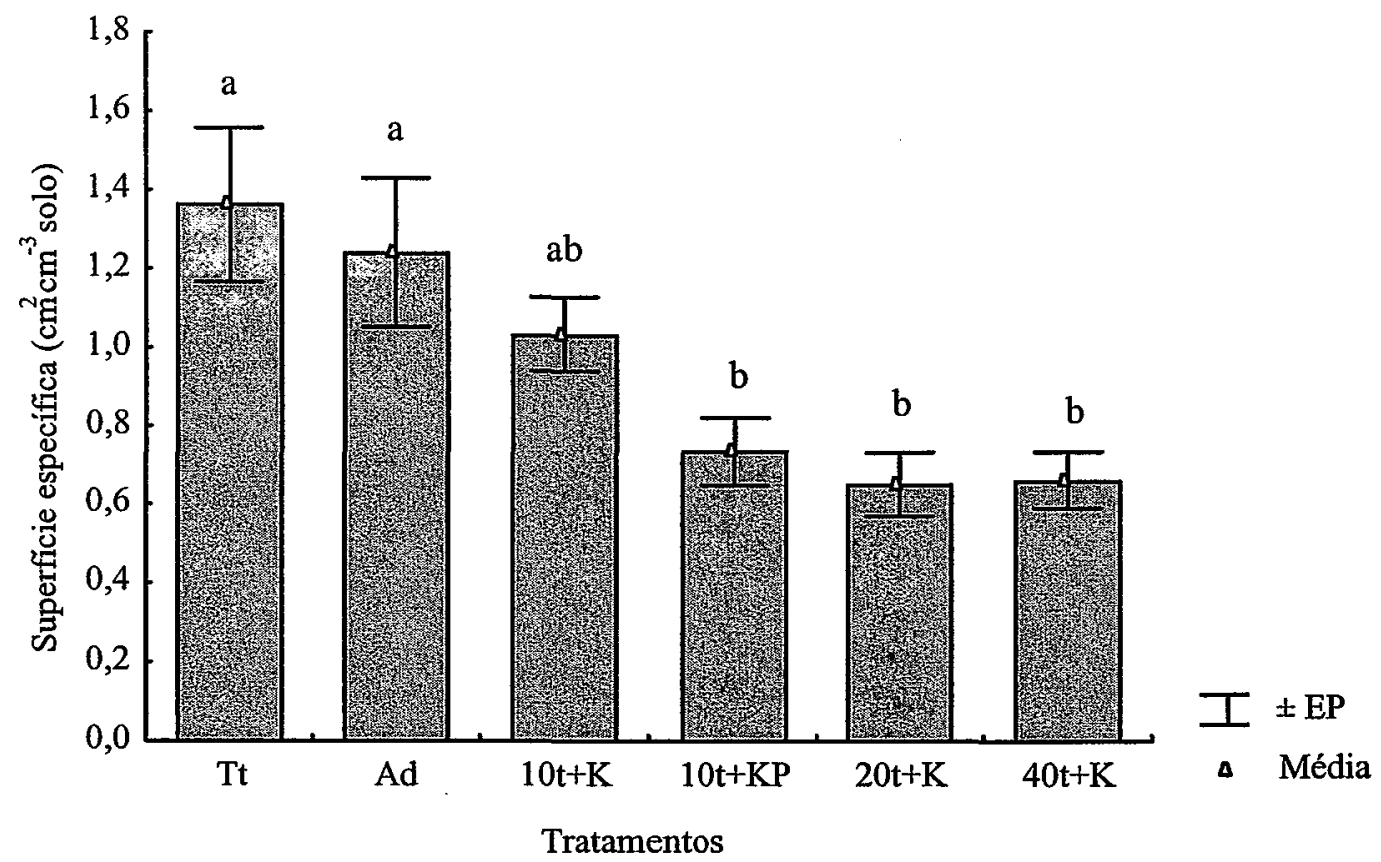

Figura 19 - Superfície específica de raízes finas (média \pm erro padrão), na camada entre 0 e $10 \mathrm{~cm}$, nas linhas de plantio. Médias seguidas da mesma letra não diferem estatisticamente pelo teste Tukey a $5 \%$ de probabilidade. 
Também na avaliação das amostras de raízes coletadas nas entrelinhas de plantio, o tratamento "Tt" foi o que apresentou a maior superfície específica com $1,09 \mathrm{~cm}^{2} \mathrm{~cm}^{-3}$. Entretanto, não houve diferença estatística em relação aos demais tratamentos, conforme mostra a Figura 20, devido à grande variabilidade dos dados relacionados com a densidade de raízes finas observada na Figura 12.

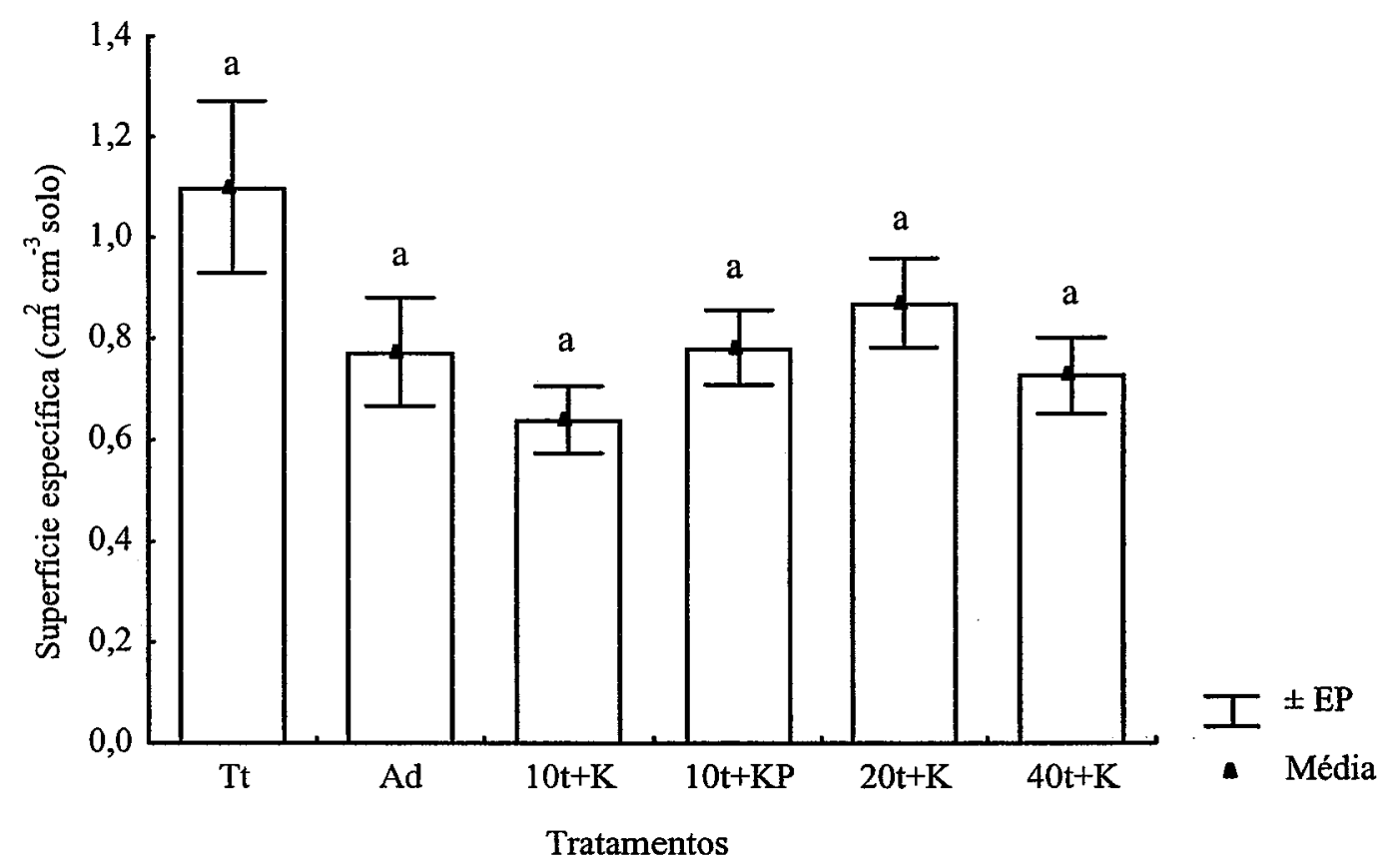

Figura 20 - Superfície específica de raízes finas (média \pm erro padrão), na camada entre 0 e $10 \mathrm{~cm}$ nas entrelinhas de plantio. Médias seguidas da mesma letra não diferem estatisticamente pelo teste Tukey a $5 \%$ de probabilidade.

No solo, a quantidade de nutrientes absorvida pela planta é determinada pela área superficial total das raízes (Kramer \& Kozlowski, 1979; Anghinoni \& Meurer, 1999). Esta é uma característica que proporciona excelente correlação com a água absorvida pelas raízes finas (Böhm, 1979). Portanto, o aumento da superfície especifica de raízes 
finas, principalmente na camada superficial do solo, contribui diretamente para a melhor absorção de água e nutrientes pelas plantas.

As equações de regressões, obtidas para a distribuição da superfície de raízes finas nos tratamentos que receberam apenas as doses crescentes de biossólido mais potássio, são aqui apresentadas quanto à posição de coleta das amostras nas linhas e entrelinhas (Figura 21). O comportamento foi similar ao da densidade de raizes finas, conforme aumentam as doses de biossólido, diminui a superfície específica.

Analisando a eficiência de absorção de nutrientes pelas raízes, Anghinoni \& Meurer (1999), observaram que a produção de raízes longas e finas é um mecanismo utilizado pelas plantas em situações de baixo suprimento nutricional. Estas observações vão de encontro aos dados observados no tratamento "Tt" (sem biossólido e sem adubação mineral). Resultados semelhantes foram encontrados por Schwengber et al., (1994), onde avaliaram o efeito do gesso e calcário sobre as raizes de seringueiras, observaram que a testemunha apresentou maior aumento na densidade e na superfície específica radicular.

A proliferação de raízes em ambientes de menor concentração de nutrientes é um comportamento adaptativo bem conhecido e já discutido anteriormente. A produção de raízes longas e finas são também características desejáveis para aumentar a eficiência de absorção de nutrientes pouco móveis no solo (Barber, 1995).

Tendo por base também os estudos efetuados por Reis et al., (1985), Gonçalves, (1994) e Mello, (1997), conclui-se que, quanto mais produtivo for o sítio, menos desenvolvido será o sistema radicular de absorção. Portanto, as árvores do tratamento "Tt" crescem sob condições edáficas (químicas, físicas e microbiológicas) menos favoráveis que as árvores dos tratamentos que foram submetidos à adubação mineral e a doses crescentes de biossólido. Assim, para atenderem às suas demandas nutricionais, precisam de um sistema radicular de absorção mais efetivo (maior área superficial), capaz de absorver, em quantidade e qualidade, os nutrientes no solo. 
(A)

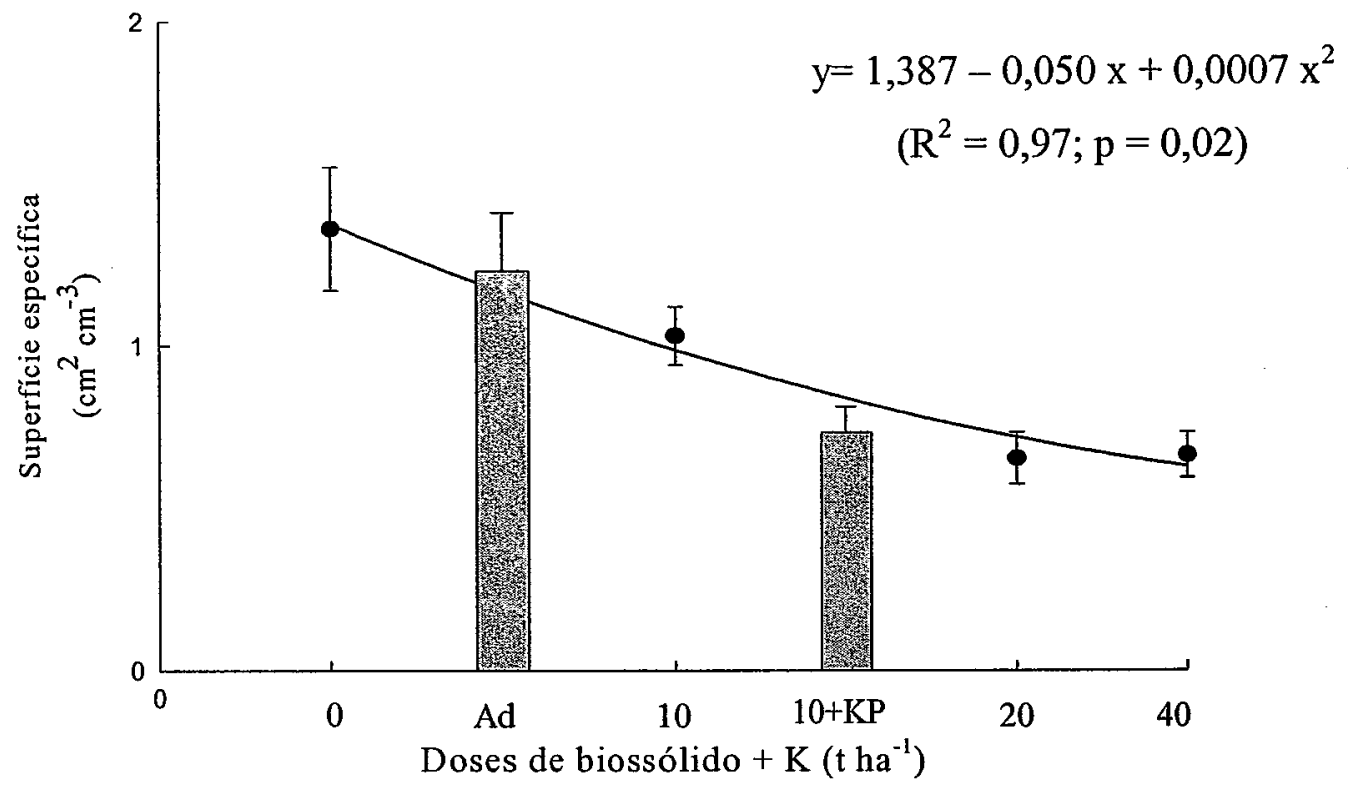

(B)

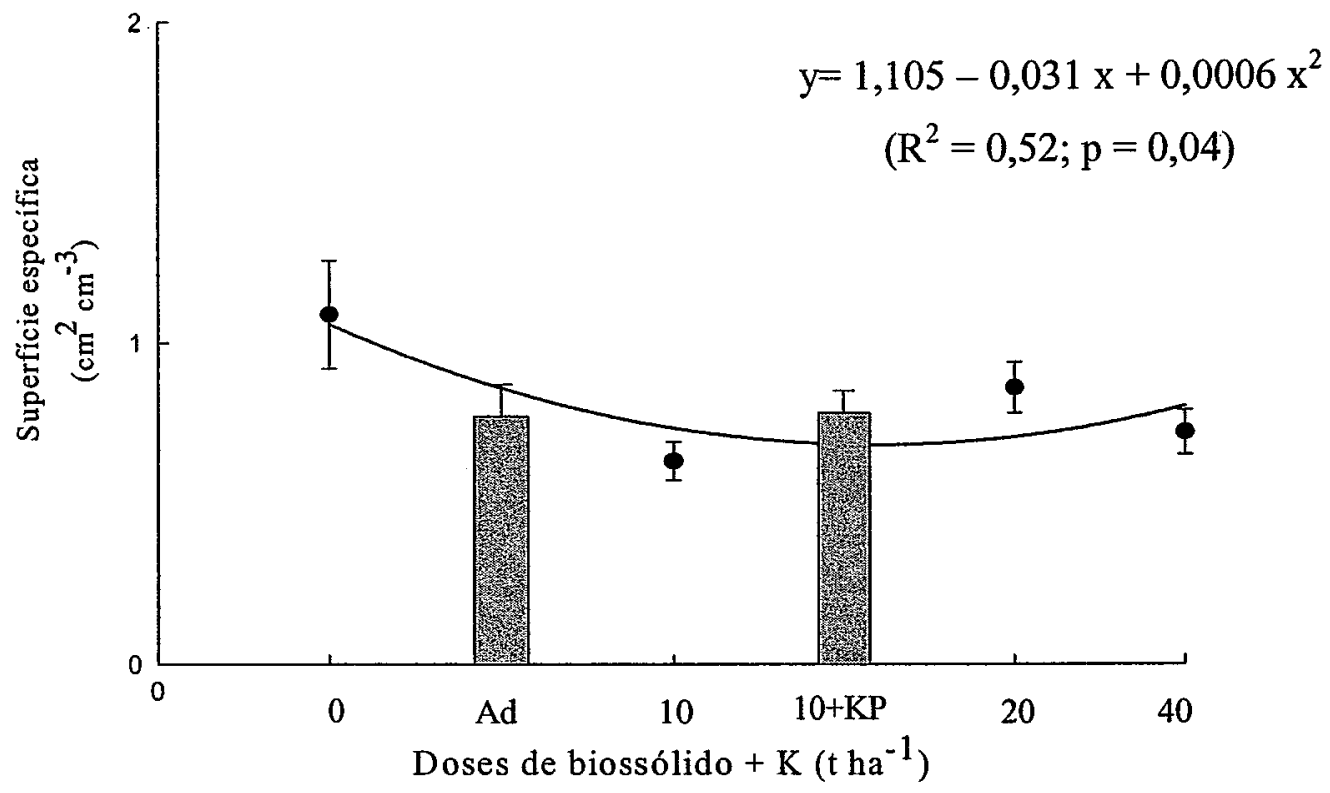

Figura 21 - Superfície específica de raízes finas coletadas nas linhas (A) e nas entrelinhas (B) de plantio na camada entre 0 e $10 \mathrm{~cm}$, em função das doses crescentes de biossólido $+\mathrm{K}$. 


\section{CONCLUSÕES}

1) As variações de densidade, diâmetro e superfície específica de raízes finas entre os tratamentos ${ }_{3}$ ocorreram de forma significativa somente na camada entre 0 e $10 \mathrm{~cm}$ de profundidade do solo. Na camada inferior, entre 10 e $30 \mathrm{~cm}$, não houve variação entre os tratamentos.

2) Em geral, os resultados obtidos não confirmam a hipótese de que a aplicação de doses crescentes de biossólido aumentaria a densidade, o diâmetro e a superfície específica de raízes finas. Ao contrário, considerando todos os pontos amostrados (linhas mais entrelinhas) observou-se um decréscimo significativo da densidade e da superfície específica das raízes finas.

3) Na camada superficial do solo (0 e $10 \mathrm{~cm}$ ), nas linhas de plantio, a densidade, o diâmetro e a superficie específica de raízes finas diminuíram significativamente com o aumento das doses de biossólido. Já nas entrelinhas as variações observadas foram menos evidentes.

4) Doses crescentes de biossólido, de 0 a $40 \mathrm{t} \mathrm{ha}^{-1}$, tendem a aumentar a área basal das árvores dos eucaliptos e portanto a ramificação e densidade das copas. Conseqüentemente, o tratamento "Tt" (sem biossólido e sem adubação mineral) apresentou uma menor área basal, maior incidência de energia radiante no subbosque e as temperaturas do solo mais elevadas na superfície e a $10 \mathrm{~cm}$ de profundidade. 


\section{REFERÊNCIAS BIBLIOGRÁFICAS}

ABER, J.C.; MELILLO, J.M., NADELHOFFER, K.J.; McCLAUGHERTY, C.A.; PASTOR, J. Fine root turnover in forest ecosystems in relation to quantity and form of nitrogen availability: a comparison of two methods. Oecologia, v.66, p.317-321, 1985.

ACADEMIA DE CIÊNCIAS DO ESTADO DE SÃO PAULO. Glossário de ecologia. São Paulo, 1997. 352p.

ANDREOLI, C.V.; PEGORINI, E.S. Proposta de roteiros para elaboração de planos de distribuição de lodo. In: SEMINÁRIO SOBRE GERENCIAMENTO DE BIOSSÓLIDOS DO MERCOSUL, 1., Curitiba, 1998. Anais. Curitiba: SANEPAR; ABES, 1998a. p.291-300.

ANDREOLI, C.V.; PEGORINI, E.S. Gestão de biossólidos: Situação e perspectivas. In: SEMINÁRIO SOBRE GERENCIAMENTO DE BIOSSÓLIDOS DO MERCOSUL, 1., Curitiba, 1998. Anais. Curitiba: SANEPAR; ABES, 1998b. p.11-18.

ANGHINONI, I.; MEURER, E.J. Eficiência de absorção de nutrientes pelas raízes. In: WORKSHOP SOBRE SISTEMA RADICULAR: METODOLOGIAS E ESTUDO DE CASO, Aracaju, 1999. Anais. Aracaju: EMBRAPA Tabuleiros Costeiros, 1999. p.57-87.

ANSARI, S.A.; KUMAR, P.; GUPTA, B,N. Root surface area measurements based on adsorption and desorption of nitrite. Plant and Soil, v.175, p.133-137, 1995.

ASSOCIAÇÃO BRASILEIRA DE NORMAS TÉCNICAS. Fórum nacional de normatização: NBR 10.004 resíduos sólidos. Rio de Janeiro, 1997. p.63.

BADWILL, P.J.; STEWART, H.T.L. Distribution, length and weight of roots in young plantation of Eucalyptus grandis W. Hill ex Maiden irrigated with recycled water. Plant and Soil, v.97, n.2, p.243-52, 1987. 
BARBER, S.A. Soil nutrient biovailability: a mechanistic approach. New York: John Wiley, 1995. 414p.

BAZZAZ, F.A. The physiological ecology of plant succession. Annual Review of Ecology and Systematic, v.10, p.351-71, 1979.

BERISH, C.W.; EWEL, J.J. Root development in simple and complex tropical successional ecosystems. Plant and Soil, v. 108, p73-84, 1988.

BERNARDES, M.S. Fotossíntese no dossel das plantas cultivadas. In: CASTRO, P.R.C.; FERREIRA, S.O.; YAMADA, T. (Ed.) Ecofisiologia da produção agrícola. Piracicaba: Associação Brasileira de Pesquisas de Potássio e do Fosfato, 1987. p13-48.

BETTIOL,W.; CARVALHO, P.C.T.; FRANCO, B.J.D.C. Utilização do lodo de esgoto como fertilizante. O Solo, v.75, n.1, p.44-54, 1982.

BIDONE, F.R A. Alternativas de disposição final de biossólidos: Aterros, Landfarming e Incineração. In: SEMINÁRIO SOBRE GERENCIAMENTO DE BIOSSÓLIDOS DO MERCOSUL, 1., Curitiba, 1998. Anais. Curitiba: SANEPAR, ABES, 1998. p.131-135.

BÖHM, W. Methods of studying root systems. Berlin: Springer-Verlag, 1979. 188p.

BOWEN, G.D. Tree roots and the use of soil nutrients. In: BOWEN, G. D. \& NAMBIAR, E. K. S. Nutrition of plantation forests. Academic London: Press, 1984. p.147-179.

CAMARGO, O.A. de; MUNIZ, A.C.; JORGE, J.A. VALADAREZ, J.M.A.S. Métodos de análise mineralógica e física de solo do Instituto Agronômico de Campinas. Campinas: AC, 1986. 94p. (IAC Boletim Técnico), $n^{\circ} 5$.

CENTRO NACIONAL DE REFERÊNCIAS EM GESTÃO AMBIENTAL URBANA. Utilização agrícola do lodo de esgoto como fertilizante. htpp://www.bsi.com.br/unilivre/centro/experiencia/experiencia/015.html. $\quad(27$ jun 2001).

COMPANHIA DE TECNOLOGIA DE SANEAMENTO AMBIENTAL. Procedimentos para o controle de resíduos sólidos industriais. São Paulo, 1997. 2v.

COMPANHIA DE TECNOLOGIA DE SANEAMENTO AMBIENTAL. Aplicação de lodos de sistemas de tratamento biológico em áreas agrícolas - Critérios para projetos e operação, manual técnico P 4.230. São Paulo, 1999. 32p. 
COMPANHIA DE SANEAMENTO DO PARANÁ. Manual técnico para utilização agrícola do lodo de esgoto no Paraná. Curitiba, 1997. p.96.

CHIARANDA, R. Efeitos da compactação do solo em mudas de Eucalyptus toreliana F, MUELL e de Eucalyptus grandis HILL EX MAIDEN. Piracicaba, 1989. 118p. Dissertação (Mestrado) - Escola Superior de Agricultura "Luiz de Queiroz", Universidade de São Paulo).

CUEVAS, E.; BROWN, S.; LUGO, A.E. Above and belowground organic matter storages and production in a tropical pine plantation and a paired broad-leaved secondary forest. Plant and Soil, v.135, p.252-268, 1991.

DELTA T SCAN. Image analysis software: user manual. England: Kirchhof \& Pendar, 1993. 244p.

DELTA T. Root washer: user manual. England: Kirchhof \& Pendar, 1995. 14p.

DESCHAMPS, C.; FAVARETTO, N. Efeito do lodo de esgoto complementado com fertilizante mineral na produtividade de desenvolvimento da cultura de feijoeiro e do girassol. SANARE, v.8, n.8, p.33-36, 1997.

DOMISCH, T.; FINER, L.; LEHTO, T. Effects of soil temperature on biomass and carbohydrate allocation in Scots pine (Pinus sylvestris) seedlings at the beginning of the growing season. Tree Physiology, v.21, n.7, p.465-472, 2001.

DONOVAN, J. F. Getting the sludge rule on line. Biocycle, v.34, n.4, p 40-42, 1993.

EISSENSTAT, D.M. Costs and benefits of constructing roots of small diameter. Journal of Plant Nutrition, v.15, p.763-782, 1992.

FAHEY, T.J.; HUGHES, J.W. Fine root dynamics in a northern hardwood forest ecosystem, Hubbard Brook Experimental Forest, NH. Journal of Ecology, v.82, p.533-548, 1994.

FARIAS, J.A.C.; OLIVEIRA, O.S.; FRANCO, E.T.H. Crescimento inicial do Guatambu, Balfourodendron riedelianum (Engl.) Engl., em diferentes intensidades luminosas. Ciência Florestal Santa Maria, v.5, n.1, p.69-89, 1995.

FARIA, L.C. Fertilização de povoamentos de eucalipto com o biossólido da ETE de Barueri, SP: demanda potencial e nível mínimo de resposta. Piracicaba, 2000. 85p. Dissertação (Mestrado) - Escola Superior de Agricultura "Luiz de Queiroz", Universidade de São Paulo. 
FERNANDES, F. Estabilização e higienização do biossólido. In: BETTIOL, W.; CAMARGO, O.A. Impacto ambiental do uso agrícola do lodo de esgoto. Jaguariúna: EMBRAPA Meio Ambiente, 2000. cap.3, p.45-67.

FISHER, R.F.; BINKLEY, D. Ecology and management of forest soils. New York: John Wiley, 2000. 489p.

FOESS, G.W.; SIEGER, R.B. Pathogen vector attraction requirements of the sludge rules. Water/Engineering \& Management, v.140, n.6, p.25-26, 1993.

FOGEL, R. Mycorrhizae and nutrient cycling in natural forest ecosystems. New Physiologist, v.86, p.199-212, 1980.

GARDNER, F.P.; PEARCE, R.D.; MITCHELL, R.L. Physiology of crop plants. Ames: Iowa University Press, 1985. 327p.

GONÇALVES, J.L.M. Características do sistema radicular de absorção do Eucalyptus grandis sob diferentes condições edáficas. Piracicaba, 1994. 84p. Tese (Livre Docência) - Escola Superior de Agricultura 'Luiz de Queiroz', Universidade de São Paulo.

GONÇALVES, J.L.M.; BENEDETTI, V. Nutrição e fertilização florestal. Piracicaba: IPEF, 2000. 427p.

GONÇALVES, J.L.M.; DEMATTÊ, J.L.I.; COUTO, H.T.Z. Relações entre produtividade de sítios florestais de Eucalyptus grandis e Eucalyptus saligna com as propriedades de alguns solos de textura arenosa e média no Estado de São Paulo. IPEF, n.43/44, p.24-39, 1990.

GONÇALVES, J.L.M.; VAZ, L.M.S.; AMARAL, T.M.; POGGIANI, F. Aplicabilidade de Biossólido em plantações florestais - efeito na fertilidade do solo, nutrição e crescimento das árvores. In: Impacto ambiental do uso agrícola do lodo de esgoto. Jaguariúna: EMBRAPA Meio Ambiente, 2000. cap.9, p.179-195.

GOLDSTEIN, N. EPA releases final sludge management rule. BioCycle, v.34, n.1, p.59-63, 1993.

GUEDES, M.C. Efeito do lodo de esgoto (Biossólido) sobre a nutrição, ciclagem de nutrientes e crescimento de sub-bosque, em plantação de eucalipto. Piracicaba, 2000. 74p. Dissertação (Mestrado) - Escola Superior de Agricultura "Luiz de Queiroz", Universidade de São Paulo. 
GUEDES, M.C.; POGGIANI, F. Dados preliminares sobre nutrição de eucalipto cultivado com lodo de esgoto (Biossólido) (Compact disc). In: SIMPÓSIO DE FERTILIDADE E NUTRIÇÃO FLORESTAL, Piracicaba, 1999. Piracicaba: IPEF, 1999.

HARRISON, R.; XUE, D.; COLE, D.W. Log-term effects of heavy applications of biosolids on organic matter and nutrient content of a coarse-textured forest soil. Forest Ecology and Management, v.66, p.165-177, 1994.

HENRY, C.L.; COLE, D.W.; HINCKLEY, T.M.; HARRISON, R.B. The use of municipal and pulp paper sludge to increase production in forestry. Journal of Sustainable Forestry, v.1, n.3, p.41-45, 1993.

HENRY, C.L.; COLE, D.W.; HARRISON, R.B.; BENGTSSON, J.; LUNDKVISK, H. Use of municipal sludge to restore and improve site productivity in forestry: the Pack Forest Sludge Research Program. Forest Ecology and Management, v.66, n.1/3, p.137-149, 1994.

JOHANSEN, D.A. Plant micro technique. New York: Mc Graw-Hill Book, 1940. $523 \mathrm{p}$.

JORDAN, C.F. Nutrient cycling in tropical forest ecosystems. New York: John Wiley, 1985. 190p.

KRAMER, P.J.; BOYER, J.S. Water relations of plants and soils New York: Academic Press, 1995. cap. 5, p. 115-166: Root and root systems.

KRAMER, P.J.; KOZLOWSKI, T.T. Physiology of woody plants. London: Academic Press, 1979. $811 \mathrm{p}$.

LARCHER,W. Ecofisiologia vegetal. São Carlos: RiMa, 2000. 531p.

LEHMANN, J.; ZECH, W. Fine root turnover of irrigated hedgerow intercropping in Northern Kenya. Plant and Soil, v.198, p.19-31, 1998.

LELES, P.S.S. Crescimento, alocação de biomassa e distribuição de nutrientes e uso de água em E. camaldulensis e E. pellita sob diferentes espaçamentos. Viçosa, 1995. 133p. Dissertação (Mestrado) - Universidade Federal de Viçosa.

LÖHMUS, K.; IVASK, M. Decomposition and nitrogen dynamics of fine roots of Norway spruce (Picea abies (L.) Karst.) at different sites. Plant and Soil, v.168169, p.89-94, 1995. 
LUDUVICE, M. Gestão de biossólido do Mercosul. In: SEMINÁRIO SOBRE GERENCIAMENTO DE BIOSSÓLIDO DO MERCOSUL, 1., Curitiba, 1998. Palestras. Curitiba: SANEPAR; ABES, 1998. p.9-10.

MACDUFF, J.H.; WILD, A.; HOPPER, M.J.; DHANOA, M.S. Effects of temperature on parameters of root growth relevant to nutrient uptake: Measurements on oilseed rape and barley grown in flowing nutrient solution. Plant and Soil, v.94, p.321$332,1986$.

MARTINS, L.G.C.; VALLE, C.F. do; BARROS, N.F. de. Efeito da aplicação do lodo da industria de papel e celulose sobre características do solo e sobre a biomassa de raizes de eucalipto. In: CONFERENCIA IUFRO SOBRE SILVICULTURA E MELHORAMENTO DE EUCALIPTOS. Salvador, 1997, Anais. Colombo: EMBRAPA; CNPF, 1997, v.3, p.167-173.

MARSHALL,J.D.; WARING, R.H. Predicting fine root production and turnover by monitoring root starch and soil temperature. Canadian Journal Forest Research, v.15, p.791-800, 1985.

MEIER, C. E.; GRIER, C.; COLE, D.W. Below and aboveground N and P use by Abies mabilis stands. Ecology, v.66, p.1928-1972, 1985.

MELO, W.J.; MARQUES, M.O.; SANTIAGO, G.; CHELLI, R.A.; LEITE, S.A.S. Efeito de doses crescentes de lodo de esgoto sobre frações da matéria orgânica e CTC de um latossolo cultivado com cana-de-açúcar. Revista Brasileira Ciência do Solo, v.18, p.449-455, 1994.

MELLO, S.L.M. Características do sistema radicular de povoamento de Eucaliptos propagados por sementes e estacas. Piracicaba, 1997. 79p. Dissertação (Mestrado) - Escola Superior “Luiz de Queiroz”, Universidade de São Paulo.

McCLAUGHERTY, C.A.; ABER, J.D.; MELILLO, J.M. The role of fine roots in the organic matter and nitrogen budgets of two forested ecosystems. Ecology, v.63, n.5, p.1481-90, 1982.

NAMBIAR, E.K.S. Root development and configuration in intensively managed radiata pine plantations South Australia. Plant and Soil, v.71, p.37-47, 1983.

OLIVEIRA, F.C. Disposição de Lodo de Esgoto e composto de lixo urbano num Latossolo Vermelho-Amarelo cultivado com cana de açúcar. Piracicaba, 2000. 247p. Tese (Doutorado) - Escola Superior de Agricultura "Luiz de Queiroz", Universidade de São Paulo. 
PAIVA, A.V.; POGGIANI, F. Crescimento de mudas de espécies arbóreas nativas plantadas no sub-bosque de um fragmento florestal. Scientia Forestalis, n. 57, p.141-151, 2000 .

PERSSON, H. A. The distribution and productivity of fine root in boreal forest. Plant and Soil, v.71, p.87-121, 1983.

PESSOTTI, F.E.S. Levantamento detalhado dos solos do Horto de Itatinga. Piracicaba: ESALQ, Departamento de Ciências Florestais, 1994. 105p.

POGGIANI, F.; GUEDES, M.C.; BENEDETTI, V. Aplicabilidade do Biossólido em plantações florestais. I. reflexo no ciclo dos nutrientes. In: BETTIOL, W.; CAMARGO, O. A. Impacto ambiental do uso agrícola do lodo de esgoto. Jaguariúna: EMBRAPA Meio Ambiente, 2000. cap.8, p.163-178.

POLGLASE, P.J.; MYERS, B.J. Tree plantations for recycling efluent and biosolids in Australia. In: ELDRIDGE, K.G.; CROWE, M.P.; OLD. K.M. Environmental management: the role of Euclyptus and other fast growing species. Australia: CSIRO, 1995, p.100-109.

RAIJ, B.van Uso agrícola de Biossólidos. In: SEMINÁRIO SOBRE GERENCIAMENTO DE BIOSSÓLIDO DO MERCOSUL, 1., Curitiba, 1998. Palestras. Curitiba: SANEPAR; ABES, 1998. p.147-151.

RAIJ, B van; QUARGGIO, J.A.; CANTARELLA, H.; FERREIRA, M.E.; LOPES, A.S.; BATAGLIA, O.C. Análise química do solo para fins de fertilidade. Campinas: Fundação Cargill, 1987. 170p.

REIS, M.G.F.; BARROS, N.F.; KIMMINS, J.P. Acúmulo de nutrientes em uma seqüência de idade de Eucalyptus grandis W.Hill (ex-Maiden) plantado no cerrado em duas áreas com diferentes produtividade, em Minas Gerais. Revista Árvore, v.11, n.1, p.1-15, 1987.

REIS, M.G.F.; KIMMINS, J.P.; REZENDE, G.C. de; BARROS, N.F. de. Acúmulo de biomassa em uma seqüência de idade de Eucalyptus grandis plantado no cerrado em duas áreas com diferentes produtividades. Revista Árvore, v.9, n.2, p.149-162, 1985.

ROCHA, M.T. Utilização de lodo de esgoto na agricultura: um estudo de caso para as bacias hidrográficas dos Rios Piracicaba, Capivari e Jundiaí. Piracicaba, 1998. 140p. Dissertação (Mestrado) - Escola Superior "Luiz de Queiroz", Universidade de São Paulo. 
ROGALLA, F. Produção, caracterização e processamento de biossólidos. In: SEMINÁRIO SOBRE GERENCIAMENTO DE BIOSSÓLIDOS DO MERCOSUL, 1., Curitiba, 1998. Anais. Curitiba: SANEPAR; ABES, 1998. p.35-40.

SALCEDO, I.; LEITE; VASCONCELOS, E.; SOUZA, F.; SAMPAIO, E. Produção de raízes finas sob vegetação de Caatinga. In: WORKSHOP SOBRE SISTEMA RADICULAR: METODOLOGIAS E ESTUDO DE CASO, Aracaju, 1999. Anais. Aracaju: EMBRAPA Tabuleiros Costeiros, 1999. p.139-152.

SANFORD, R.L.JR.; CUEVAS, E. Root growth and rhizosphere interactions in tropical forests. In: MULKEY, S.; CHAZDON, R.L.; SMITH, AP. Tropical forest plant ecophisiology. New York: Chapman \& Hall. 1996. cap.10, p.268-300.

SANTOANTONIO, D.; HERMANN, R.K.; OVERTON, W.S. Root biomass studies in forest ecosystem. Pedobiologia, v.17, p.1-31, 1977.

SANTOS, H. F.; TSUTIYA, M. T. Aproveitamento e disposição final do lodo de estações de tratamento do Estado de São Paulo. Engenharia Sanitária e Ambiental, v.2, n.2, p.70-82, 1997.

SCHWENGBER, D.R.; VENTURIN, N.; CARVALHO, J.G. Efeitos do gesso e calcário na relação raiz/parte aérea e em características das raízes de tocos de seringueira (Hevea spp) recém implantados em campo. CERNE, v.1, n.1, p.38-44, 1994.

STRAUS, E.L.; NETO, V.A. Normatização e monitoramento da gestão de biossólidos. Exigências ambientais para a aplicação de biossólidos em áreas agrícolas. In: SEMINÁRIO SOBRE GERENCIAMENTO DE BIOSSÓLIDOS DO MERCOSUL, 1., Curitiba, 1998. Anais. Curitiba: SANEPAR; ABES, 1998. p.301-306.

STRAUS, E.L. Normas da utilização de lodos de esgoto na agricultura. In: BETTIOL, W.; CAMARGO, O.A. Impacto ambiental do uso agrícola do lodo de esgoto. Jaguariúna: EMBRAPA Meio Ambiente, 2000. cap.13, p. 215-224.

SPURR, S.H.; BARNES, B.V. Ecologia forestal. México: AGT, 1982. 690p.

SUTTON, R. F. Root system morphogenesis. New Zealand Journal Forest Science, v.10, p.264-92, 1980.

TAYLOR, H.M.; JORDAN, W.R.; SINCLAIR, T.R. Managing root systems for efficient water use: an overview. In: TAYLOR, H.M. Limitations to efficient use in crop production. Madison: American Society of Agronomy, 1983. cap. 3A, p. 87-113. 
TSUTYA, M.T. Alternativas de disposição final de biossólido gerados em estações de tratamento de esgoto. In: BETIOL, W.; CAMARGO, O.A. Impacto ambiental do uso agrícola do lodo de esgoto. Jaguariúna: EMBRAPA MEIO AMBIENTE, 2000, cap.4, p.69-106.

TSUTYA, M.T. Características de biossólidos em estações de tratamentos de esgoto. In: TSUTYA, M.T. (Ed.), Biossólidos na agricultura. São Paulo: SABESP, 2001. cap. 4 , p. 89-131.

VANZO, J.E.; MACEDO, L.S.; TSUTYA, M.T. Registros da produção de biossólidos: o caso da ETE Franca. In: TSUTYA, M.T. (Ed.), Biossólidos na agricultura. São Paulo: SABESP, 2001. cap. 8, p. 227-242.

VAZ, L.M.S. Crescimento inicial, fertilidade do solo e nutrição de um povoamento de Eucalyptus grandis fertilizado com biossólido. Piracicaba, 2000. 41p. Dissertação (Mestrado) - Escola Superior de Agricultura "Luiz de Queiroz", Universidade de São Paulo.

VLAWIS, J.; WILLIANS, E. Utilization of municipal organic wastes as agricultural fertilizers. California Agricultural, v.25, n.7, p.7-9, 1971.

VOGT, K.A.L.; EDMONDS, R. L.; GRIER, C. C. Seasonal changes in biomass and vertical distribution of mycorrhizal and fibrous-textured conifer fine roots in 23 and 180 year-old sub alpine Abies amabils stands. Canadian Journal Forest Research, v.11, p.223-229, 1981.

VOGT, F.A.; GRIER, C.; VOGT, D.J. Production, turnover and nutrient dynamics of above and belowground detritus of world forest. Advances in Ecological Research, v.15, p.303-377, 1986.

WALTER, H. Ecology of tropical and subtropical vegetation. Edinburgh, Oliver \& Boyd, 1971. 539p.

WATER ENVIRONMENTAL FEDERATION. RESIDUALS MANAGEMENT COMMITEE. Biosolids and the 503 Standards, v5, n.5, p.57-62, May 1993.

WHATLEY, J.M.; WHATLEY, F.R. A luz e a vida das plantas. Trad. de G. M. Felipe. São Paulo: EDUSP, 1982. 101p.

ZABOWSKI, D.; HENRY, C.L. Soil and foliar nitrogen after fertilizer treatment of Pinus ponderosa. New Zealand Journal of Forestry Science, v.24, n.2-3, p.333-343, 1994. 